\title{
RECUPERAÇÃO DE UM \\ FRAGMENTO FLORESTAL COM \\ SISTEMAS AGROFLORESTAIS
}

\author{
DENISE BITTENCOURT AMADOR \\ Bióloga
}

Orientador : Prof. Dr. VIRGILIO VIANA

Dissertação apresentada à Escola Superior de Agricultura "Luiz de Queiroz", Universidade de São Paulo, para obtenção do título de Mestre em Ciências, área de concentração: Ciências Florestais.

PIRACICABA

Estado de São Paulo - Brasil

Maio - 1999 


\section{ERRATA}

\section{Página 34.}

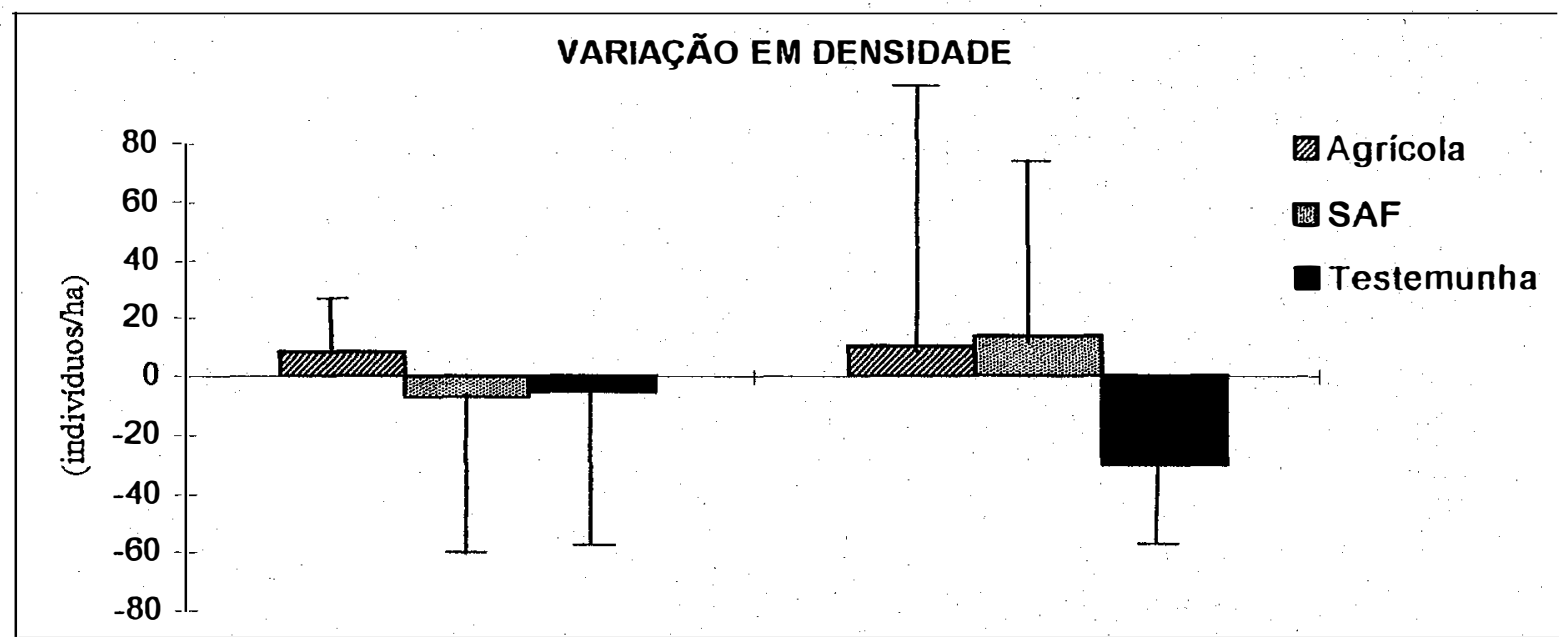

Figura 10. Variação em densidade de árvores com DAP $\geq 5 \mathrm{~cm}$ nos tratamentos 1 , poda de cipós e plantio agrícola, 2, poda de cipós e plantio agroflorestal e 3, testemunha em um ano.

\section{Página 44.}

Tabela 11. Custos das operações e dos tratamentos 1 , podà de cipós e plantio agrícola e 2, poda de cipós e plantio agroflorestal, em reais (R\$) e em dólar (US\$).

\begin{tabular}{|c|c|c|}
\hline$\because$ & $\begin{array}{c}\text { Custo da área } \\
\text { experimental }\left(4270 \mathrm{~m}^{2}\right) \\
\mathrm{R} \$ \text { / US\$* }\end{array}$ & $\begin{array}{c}\text { Custo estimado do } \\
\text { experimento para um } \\
\text { hectare } \\
\text { R\$ / US\$* } \\
\end{array}$ \\
\hline $\begin{array}{l}\text { Custo de toda a área experimental - } \\
\text { tratamentos } 1 \text { e } 2\end{array}$ & $558,50 / 464,14$ & $1307,95 / 1089,95$ \\
\hline $\begin{array}{l}\text { Custo do tratamento } 1 \text { - agrícola } \\
\text { (10 parcelas) }\end{array}$ & $184,00 / 153,33$ & $430,91 / 359,09$ \\
\hline $\begin{array}{l}\text { Custo do tratamento } 2 \text { - agroflorestal } \\
\text { (10 parcelas) }\end{array}$ & $374,50 / 310,81$ & $877,04 / 730,86$ \\
\hline
\end{tabular}

* valores convertidos para dólar com a cotação do mês de dezembro de $1998($ US $\$ 1=\mathrm{R} \$ 1,20)$

\section{Página 67.}

Tabela 18. Número médio, mínimo e máximo de espécies arbóreas (DAP $\geq 5 \mathrm{~cm}$ ) por parcela (de 154 a $333 \mathrm{~m}^{2}$ ) presente nas áreas de capoeira baixa na borda e no interior do fragmento.

\begin{tabular}{|l|l|l|l|}
\hline Parcela & Média & Mínima & Máxima \\
\hline Borda & 4,3 & 1 & 10 \\
\hline Interior & 6,26 & 1 & 14 \\
\hline
\end{tabular}




\section{DEDICATÓRIA}

Dedico este trabalho a meus pais, professores de vida, exemplos de idealismo e garra.

Meu pai, Elmo, grande guerreiro. Desde cedo me despertou o amor pela natureza, me ensina muito e é grande incentivador de minha carreira.

Minha mãe, Zu, puro sorriso de amor que emana alegria.

Em todo seu alto astral ensina a todos a grande lição de que

"tudo vale a pena quando a alma não é pequena".

Agradeço a oportunidade de ser fruto desta árvore e poder agora dispersar minhas sementes... 


\section{AGRADECIMENTOS}

Agradeço às pessoas que contribuíram para a realização deste trabalho e àquelas que são muito importantes na minha vida:

Ao Professor e amigo Virgílio Viana, agradeço a oportunidade deste trabalho, as idéias e os ideais, o entusiasmo, a orientação e a amizade.

Ao Professor Oldeman, pelas brilhantes idéias e observações feitas a este trabalho e por compartilhar tantas experiências vividas ao longo de sua carreira no mundo.

Ao meu amor Rodrigo, companheiro de vida, sonhos, plantios e aprendizagem junto à natureza. Agradeço o estímulo, a paciência, as críticas, as idéias, o carinho, o amor e tudo mais...

Ao pessoal do Laboratório de Silvicultura Tropical, pelas experiências trocadas e convividas, os projetos, a partilha do orientador, dos computadores e o incentivo e apoio emocional e profissional. Agradecimento especial a :

-Valquíria Garrote, amiga e companheira, que deu grande ajuda no campo, nas entrevistas e discussões;

-"Vaxp"(Leandro Pinheiro), grande "tutor" e assessor em computação, companheiro de "Projeto Fragmentos" e de fragmentos de projetos; valeu as idéias trocadas e o incentivo;

-Henrique Nascimento, pela preciosa ajuda nas análises e aprendizados estatísticos; a ferramenta se mostrou menos feia do que parecia ser...

A todos os estagiários que participaram deste trabalho com muita disposição de "botar a mão na massa", fazer e aprender : Teflon (Fermando), Piu (Daniel), Dumato (Catarina), Játomei (Ricardo), Kalígula (Leandro), Fermento (Marcelo), Lentilha (Marcos), Marisa Fonseca, Ralfo, Mateus, Daniel, Maggi (Fernanda) e Presépio. Agradecimento especial ao estagiário-agrônomo Rogério Puerta, incansável na arte de cortar cipós, grande força no campo.

Ao grupo Mutirões agroflorestais, por tantas trocas de idéias, dúvidas, conhecimentos, anseios, amor... Pelo aprendizado "com-junto" à natureza e o estímulo em acreditar cada vez mais no sonho de um mundo equilibrado e ecológico. "Sonho que se sonha junto é realidade"!

À amiga Fru (Fabiana), por toda amizade, companheirismo, dedicação e carinho. Nossos papos filosóficos e trabalhos agroflorestais reafirmam os sonhos de sinfonia com a Natureza...

À amiga Patrícia Vaz, pelas trocas, papos, vivências, ensinos e pela acolhida em "Pira".

Ao Sr. Caio, proprietário da Fazenda Capuava, pela possibilidade de desenvolver o trabalho numa floresta tão especial, e por todo o amor que tem por ela.

À Fapesp, pela concessão da bolsa e da reserva técnica, pelos pareceres com boas sugestões à este trabalho e pelo serviço de excelência que oferece à sociedade brasileira ao acreditar em nossa Ciência.

Ao Professor e amigo Paulo Kageyama, pelas conversas valiosas e sábias palavras de quem conhece e respeita a floresta e seus povos, além da grande ajuda na escolha das espécies. 
Ao Professor Ricardo Rodrigues, pela preciosa ajuda nas identificações botânicas e na discussão e revisão do trabalho.

Ao Professor Natal, por coordenar a PG em Ciências Florestais com arte e garra.

Ao Professor João Batista, pelas consultorias estatísticas.

Aos trabalhadores que participaram da implantação das áreas num trabalho árduo que inclui o corte de cipós cheios de espinhos, como o "arranha gato" e o "esporão de galo": Sr. Manézinho, Anderson, Fábio e Sr. Benedito.

Ao Sr. Gustavo, morador antigo da Capuava, grande amador e conhecedor da natureza, meu anjo da guarda durante o trabalho.

Aos funcionários e moradores da Capuava, pelo estímulo ao trabalho e as contribuições nas entrevistas.

Ao viveiro do IPEF/ESALQ, em especial ao Amarildo - responsável pelo viveiro, e ao ECOAR (Associação Ecoar Florestal) pela doação das mudas.

Ao $\mathrm{CNPq}$, pelos primeiros meses de bolsa.

Aos representantes das instituições entrevistadas, pela valiosa contribuição.

À turma da PG, pelo companheirismo nas farras e lutas, nos momentos alegres e difíceis que são peculiares à pós-graduação.

À Universidade Rural (UFRRJ), pelos maravilhosos anos de vida universitária, proporcionando vivências, experiências, aprendizados e encontros inesquecíveis.

Ao Fusquinha azul (68), “Asazul”, grande companheiro, incansável na labuta.

À Fazenda São Luiz, meu novo lar, por toda paz, inspiração e harmonia para a finalização deste trabalho.

Aos meus pais, Elmo e Zulmira, por todo o esmero na minha educação desde meus primeiros anos de vida, pelo incentivo ao mestrado, a ajuda financeira, o computador e o amor sempre... "Amadores" sempre!! Agradeço eternamente a Vida que me possibilitaram.

Aos meus irmãos e amigos, jóias preciosas na minha vida, cultivados com muito amor, agradeço a força, o amor, o amparo emocional, a luz espiritual e o companheirismo na vida.

A Deus, por me permitir tantas portas abertas, encontros especiais e oportunidades na vida. Agradeço a saúde, a alegria e o entusiasmo pela vida.

À Mãe Natureza, rainha, criadora de reinos tão perfeitos, de seres tão diversos, de harmonia tão única no Universo. Agradeço a oportunidade de ser sua aprendiz, e assim, me religar... 


\section{MOMENTO DE REFLEXÄO...}

Estamos a menos de um ano da virada do milênio, sob o vento da renovação, da revisão de conceitos, da mudança de paradigmas e da busca pela re-ligação com as outras pessoas, os outros seres, com a Terra e com Deus. Nesta direção, que visa uma relação mais harmônica do ser humano com o Universo em suas ações e suas vidas, a tendência é a visão cada vez mais holistica e integrada na observação, na pesquisa e nos atos. Sejamos mais inteiros !

É tempo de compreender a natureza para melhor dela participar, agindo a seu (nosso) favor, acompanhando seu fluxo e com ela aprender a viver o espirito de comunhão, que age afinado com a sinfonia universal. Podemos ser co-criadores! A participação de todos os seres nesta orquestra é imprescindivel. cada um em sua função, pulsando em compasso e harmonia com a natureza.

No presente trabalho deparamo-nos com alguns dos sintomas da degradação de valores e tendências da humanidade, comprovando a gravidade da situação em que nos encontramos. $A$ partir do problema prático que atinge a grande parte dos fragmentos florestais do Estado de São Paulo, assim como outras regiões do planeta, buscamos alternativas que conciliem a conservação da riqueza de nossa biodiversidade com a perpetuação de nossa espécie: a coexistência do ser humano com a natureza. O processo de desenvolvimento dominante exclui o valor da riqueza biológica, da justiça social e do respeito à diversidade cultural em prol de poder econômico, riqueza material e do usufruto imediato de nossos recursos naturais, dádiva divina para a vida neste planeta.

Este trabalho buscou gerar subsidios e fomentar a discussão acerca da viabilidade da recuperação e conservação dos fragmentos florestais no contexto sócio-cultural em que se inserem. Buscamos as pistas da natureza para diagnosticar sua condição e saber como melhor intervir e participar de sua vida e dinâmica e o envolvimento dos atores sociais é um chamado para a co-responsabilidade do processo de recuperação e conservação. Ao integrar sua participação, busca-se a afinação da orquestra.

Nós não temos tempo a perder; os rumos de Gaia estão nas nossas mãos; cabe a nós ser criativos como a natureza e conciliar teoria e prática, razão e emoção, intuição e ação, poesia e ciência...amor e amor! 
Sumário

Lista de Figuras

Lista de Tabelas

Resumo

Summary vii

CAPÍTULO I INTRODUÇÃO ix

1 INTRODUÇÃO

1.1 Desmatamento e Fragmentação

1.2 Ecologia de Fragmentos Florestais .

1.3 O Efeito de Borda e a Degradação dos Fragmentos ......................................................... 6

1.4 Conceito e Dinâmica de Eco-unidades ...................................................................... 7

1.5 A Recuperação de Fragmentos Florestais .............................................................. 12

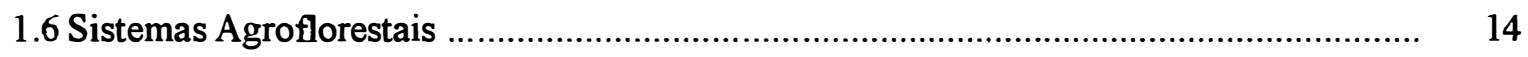

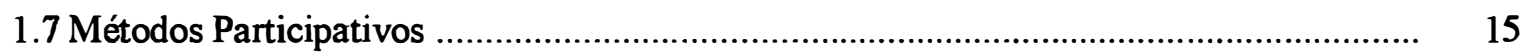

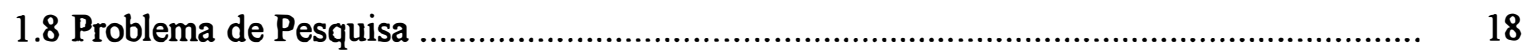

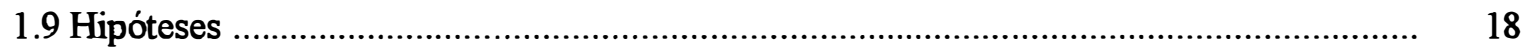

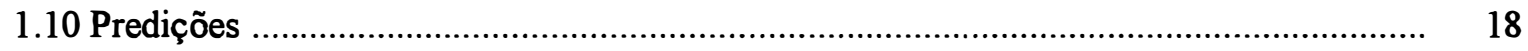

CAPÍTULO II SISTEMAS AGROFLORESTAIS PARA RECUPERAÇÃO DE UM

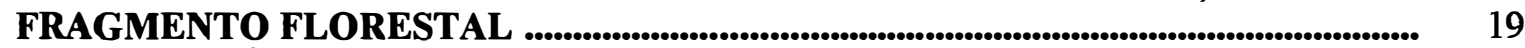

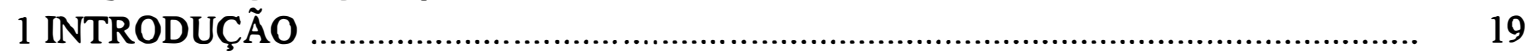

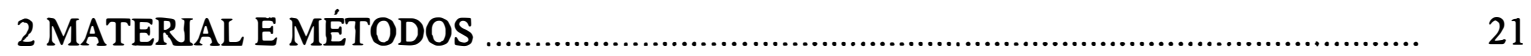

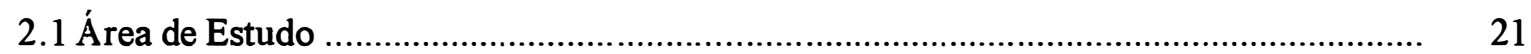

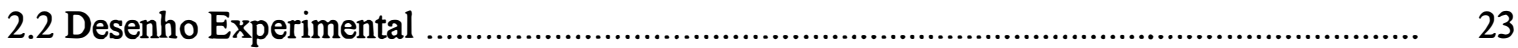

2.3 Escolha das Espécies Arbóreas e Agrícolas ............................................................ 26

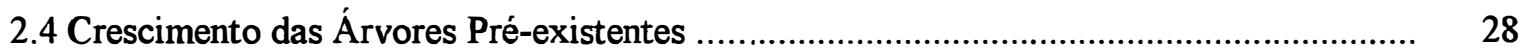

2.5 Regeneração Natural ............................................................................................. 28

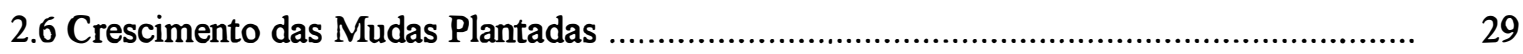

2.7 Produção das Espécies Agrícolas .............................................................................. 29

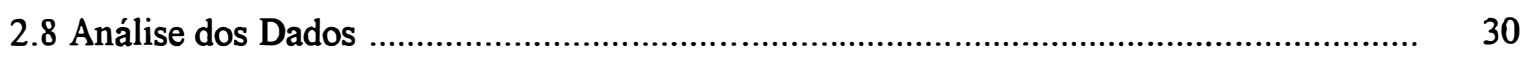

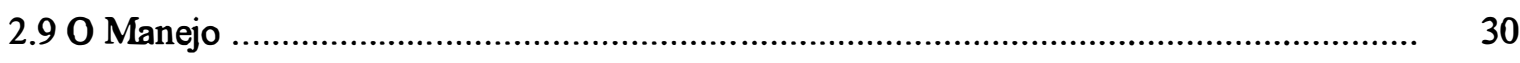

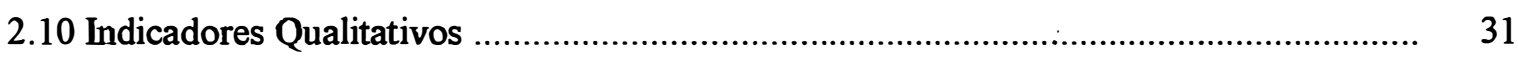

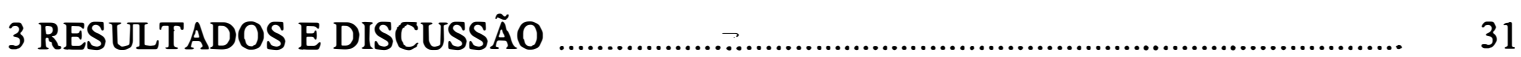


3.1 Inventário das Árvores Pré-existentes ................................................................... 31

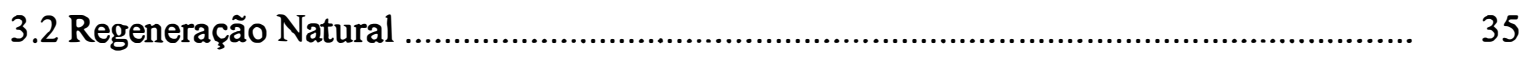

3.3 Crescimento das Espécies Arbóreas Plantadas ............................................................ 39

3.4 Produção das Espécies Agrícolas ......................................................................... 41

3.5 Análise Econômica ........................................................................................... 43

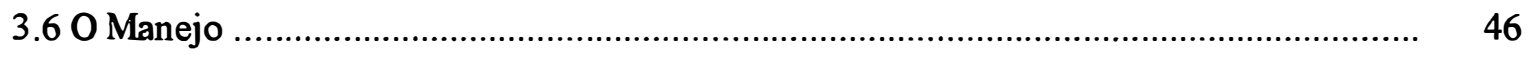

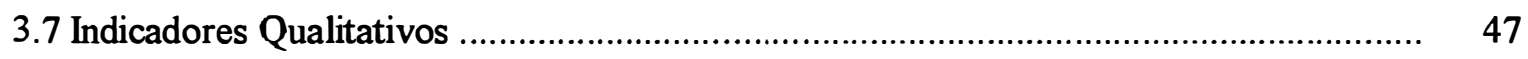

3.8 Propostas para Continuidade do Manejo ................................................................. 50

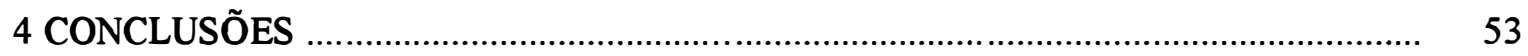

CAPÍTULO III DINÂMICA DE CAPOEIRAS BAIXAS NA RECUPERAÇÃO DE

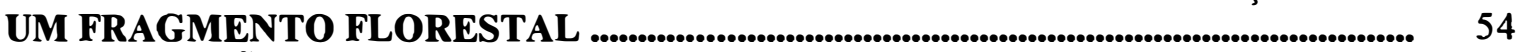

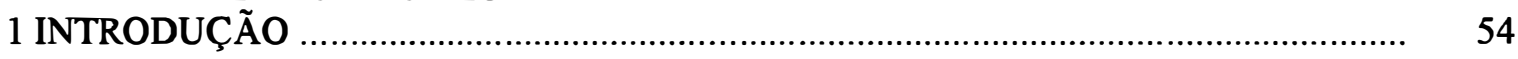

2 MATERIAL E MÉTODOS ...................................................................................... 56

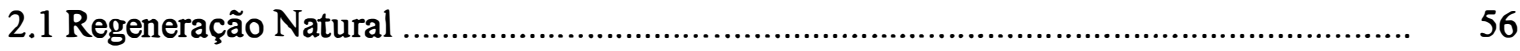

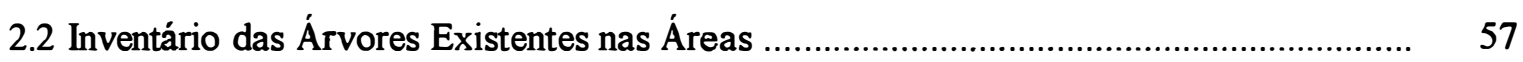

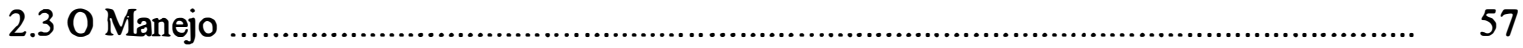

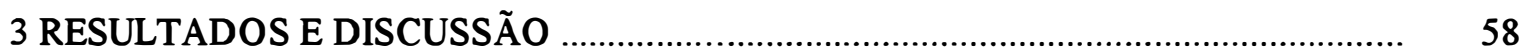

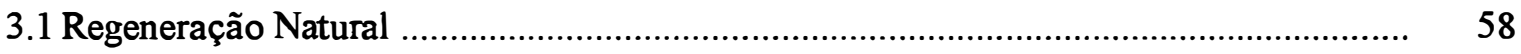

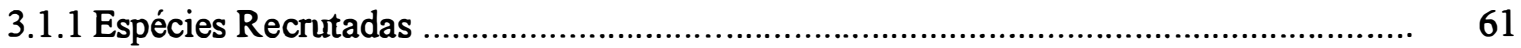

3.1.2 Espécies Recrutadas Potenciais para Uso em Propostas de Recuperação ..................... 66

3.2 Espécies Arbóreas Presentes nas Capoeiras Baixas .................................................... 66

3.3 A Dinâmica de Eco-unidades nas Capoeiras Baixas .................................................. 68

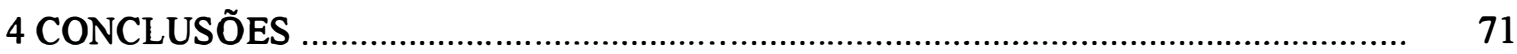

CAPÍTULO IV RELAÇÃO E PERCEPÇÃO DAS PESSOAS E INSTITUIÇÕES ENVOLVIDAS COM O FRAGMENTO CAPUAVA ........................................................ 77

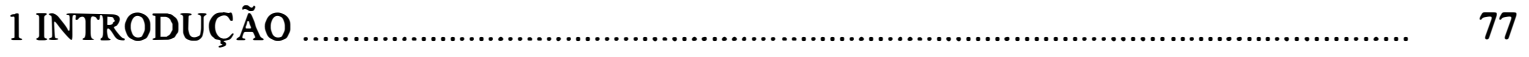

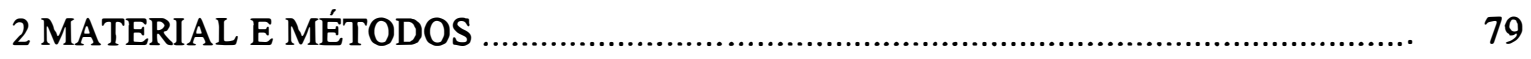

2.1 Comunidade da Fazenda Capuava ..................................................................... 80

2.2 Proprietário da Fazenda Capuava ....................................................................... 81

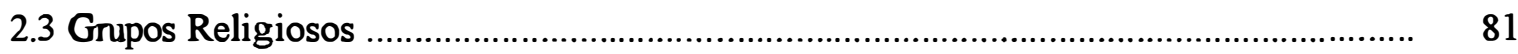

2.4 Instituições Relacionadas ao Fragmento Capuava ................................................... 81

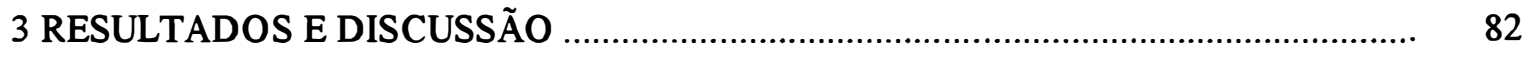

3.1 Comunidade e Moradores da Fazenda Capuava …..................................................... 83

3.2 Proprietário da Fazenda Capuava ............................................................................... 89 


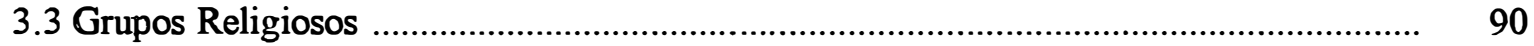

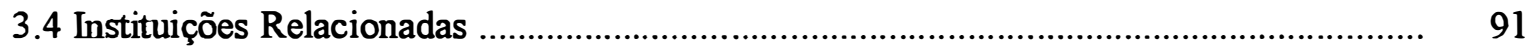

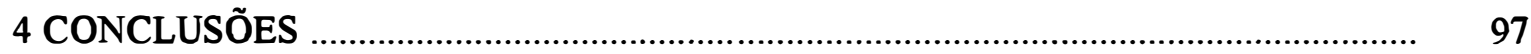

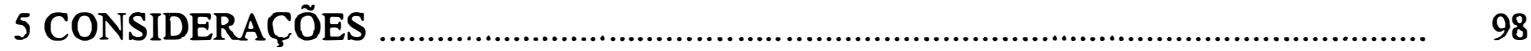

CAPÍTULO V CONSIDERAÇÕES FINAIS.................................................................... 99

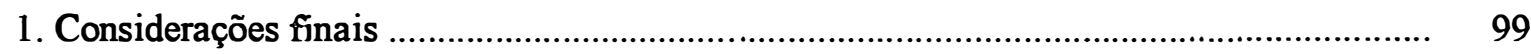

2. Prioridades de Pesquisa .................................................................................. 101

3 Prioridades na Recuperação de Fragmentos ........................................................... 103

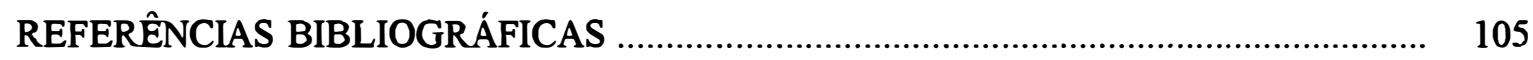


1. Evolução do desmatamento e fragmentação das florestas no Estado de São Paulo ............. 3

2. Hierarquia dos sistemas orgânicos e suas definições ....................................................... 8

3. Perfil esquemático de capoeira baixa.......................................................................... 10

4. Interface do fragmento Capuava com a matriz: a cultura da cana-de-açúcar ..................... 11

5. Eco-mosaico capoeira baixa na borda do fragmento Capuava ......................................... 11

6. Fragmentos florestais da região de Piracicaba, SP .......................................................... 22

7. Croqui do plantio nos tratamentos 1 , plantio agrícola, e 2, plantio agroflorestal ............... 23

8. Croqui do fragmento Capuava e localização das parcelas experimentais ............................ 25

9. Parcela esquemática de capoeira baixa, onde se observam as sub-parcelas de $3 \times 3 \mathrm{~m}$. para acompanhamento da regeneração natural...................................................................

10. Variação em área basal, densidade e recrutamento de árvores (DAP $\geq 5 \mathrm{~cm}$ ) nos tratamentos 1 , poda de cipós e plantio agrícola, 2, poda de cipós e plantio agroflorestal e 3 , testemunha em um ano

11. Crescimento das mudas plantadas em diâmetro da copa e altura. As medidas foram obtidas em dois intervalos de 6 meses : T1, do plantio a seis meses após o plantio, e T2, de seis meses a um ano após o plantio

12. Densidade de plântulas $(\mathrm{h} \geq 50 \mathrm{~cm})$ recrutadas nos tratamentos 1 , poda de cipós $\mathrm{e}$ plantio agrícola, 2, poda de cipós e plantio agroflorestal e 3 , testemunha, em 1 mês (T1) após a instalação do experimento, 7 meses (T2) e 1 ano (T3)

13. Dendrograma relativo às espécies arbóreas recrutadas $(\mathrm{h} \geq 50 \mathrm{~cm})$ apresentando a similaridade florística entre as parcelas, sob os tratamentos 1 , poda de cipós e plantio agrícola, 2, poda de cipós e plantio agroflorestal e 3, testemunha

14. Dossel formado por fumo bravo (Solanum granuloso-leprosum) em capoeira baixa com plantio agroflorestal, um ano após a intervenção

15. Dendrograma relativo às espécies arbóreas (DAP $\geq 5 \mathrm{~cm}$ ) apresentando a similaridade florística entre as parcelas, sob os tratamentos 1 , poda de cipós e plantio agrícola, 2 , poda de cipós e plantio agroflorestal e 3 , testemunha

16. Gráfico vetorial de vida com os sistemas e os grupos ecológicos de espécies representando a sucessão natural e o aumento de quantidade de vida

17. Órbita de relações das pessoas e instituições com o fragmento florestal da fazenda Capuava 
1. Percentual de tipos de mosaicos de eco-unidades no fragmento Capuava ........................ 10

2. Espécies arbóreas escolhidas para o plantio e suas características

3. Área basal média, mínima e máxima $\left(\mathrm{m}^{2} / \mathrm{ha}\right)$ das árvores (DAP $\geq 5 \mathrm{~cm}$ ) nas parcelas com tratamento 1 , poda dos cipós e plantio agrícola, 2, poda dos cipós e plantio agroflorestal e 3, testemunha em T1 (momento de instalação do experimento) e T2 (um ano após T1)

4. Densidade média, mínima e máxima ( $\mathrm{n}^{\circ}$. indivíduos $/ \mathrm{ha}$ ) relativa às árvores (DAP $\geq 5$ $\mathrm{cm}$ ) das parcelas com os tratamentos 1 , poda dos cipós e plantio agrícola, 2, poda dos cipós e plantio agroflorestal e 3 , testemunha em T1 (momento de instalação do experimento) e T2 (um ano após T1)

5. Resultados da ANOVA dos efeitos da posição, borda e interior, do tratamento, 1,2 e 3, e da interação dos fatores sobre o incremento em área basal, densidade e recrutamento de indivíduos (DAP $\geq 5 \mathrm{~cm}$ ) no intervalo de 1 ano

6. Resultados da ANOVA quanto aos efeitos da posição, borda e interior, e dos tratamentos sobre a densidade de plântulas $(\mathrm{h} \geq 50 \mathrm{~cm})$ em três momentos : $\mathrm{Tl}$ (1 mês após o manejo), T2 (6 meses após T1) e T3 (6 meses após T2)

7. Densidade média, mínima e máxima de plântulas/hectare nos tratamentos 1 , poda de cipós e plantio agrícola, 2, poda de cipós e plantio agroflorestal e 3, testemunha, em três momentos: um mês, sete meses e um ano após a instalação do experimento

8. Densidade da regeneração natural (plântulas/hectare) e de mudas em plantio convencional com espaçamento $3 \times 2 \mathrm{~m}$ (plantas/hectare).

9. Mortalidade das espécies arbóreas plantadas por parcela e por espécie

10. Produção agrícola $(\mathrm{kg})$ média, mínima e máxima das parcelas (de 154 a $333 \mathrm{~m}^{2}$ ) com os tratamentos 1 , plantio agrícola e 2, plantio agroflorestal, na borda e no interior do fragmento

11. Custos das operações e dos tratamentos 1 , poda de cipós e plantio agrícola e 2 , poda de cipós e plantio agroflorestal, em reais (R\$) e em dólar (US\$)

12. Total da produção agrícola e receita (em reais e em dólar) nas áreas experimentais com os tratamentos 1 , poda de cipós e plantio agrícola e 2, poda de cipós e plantio agroflorestal

13. Indicadores semi-qualitativos para avaliação das áreas experimentais. Os resultados representam a média por parcela, sete meses após a instalação do experimento, nas situações de borda e interior em cada tratamento: 1, poda de cipós e plantio agrícola, 2 , poda de cipós e plantio agroflorestal e 3 , testemunha

14. Critérios para determinar classes de capoeiras baixas

15. Classes de capoeira baixa e sugestões de manejo segundo a classificação das áreas 
16. Número de áreas experimentais dos tratamentos 1 , plantio agrícola e 2, plantio agroflorestal em cada "classe de capoeira baixa" um ano após a intervenção a intervenção.. 52

17. Número médio, mínimo e máximo de espécies arbóreas recrutadas por parcela (de 154 a $333 \mathrm{~m}^{2}$ ) e por hectare (entre parênteses) em um ano nos tratamentos 1, poda de cipós e plantio agrícola, 2 , poda de cipós e plantio agroflorestal e 3 , testemunha

18. Número médio, mínimo e máximo de espécies arbóreas (DAP $\geq 5 \mathrm{~cm}$ ) por parcela (de 154 a $333 \mathrm{~m}^{2}$ ) e por hectare (entre parênteses) presentes nas áreas de capoeira baixa na borda e no interior do fragmento

19. Dados médios dos parâmetros considerados para a avaliação da dinâmica das capoeiras baixas com os tratamentos 1 , poda de cipós e plantio agrícola, 2, poda dos cipós e plantio agroflorestal e 3, testemunha

20. Espécies presentes nas parcelas experimentais nas condições: A- regeneração natural $(\mathrm{h} \geq 50 \mathrm{~cm})$ em 1 mês, B- regeneração natural $(\mathrm{h} \geq 50 \mathrm{~cm})$ em 1 ano, $C$ - árvore (DAP $\geq$ $5 \mathrm{~cm}$ ) pré-existente, $\mathrm{D}$ - árvore (DAP $\geq 5 \mathrm{~cm}$ ) presente em 1 ano e E- muda plantada

21. Matriz de critérios para escolha de espécies agrícolas e arbóreas, elaborada pela comunidade de moradores da fazenda Capuava

22. Valores atribuídos às respostas nas entrevistas realizadas na comunidade da Capuava ..

23. Citações de alguns membros da comunidade de moradores da Fazenda Capuava durante as entrevistas

24. Entrevistas realizadas a representantes de instituições relacionadas à questão ambiental na região de Piracicaba, SP 


\title{
RECUPERAÇÃO DE UM FRAGMENTO FLORESTAL COM SISTEMAS AGROFLORESTAIS
}

\author{
Autora: DENISE BITTENCOURT AMADOR \\ Orientador: VIRGÍLIO VIANA
}

\section{RESUMO}

A expansão da fronteira agrícola foi responsável por promover a abertura de grandes áreas para monocultivos, provocando uma grande fragmentação das florestas naturais. Em paisagens intensamente cultivadas, os fragmentos florestais são, de maneira geral, pequenos, isolados e perturbados. Porém, é onde se encontra a maior parte da biodiversidade remanescente. Existem evidências crescentes de que estes fragmentos não são auto-sustentáveis e requerem não apenas a proteção contra perturbações antrópicas, mas também um manejo ativo para conservar suas populações ameaçadas de extinção. $\mathbf{O}$ alto custo de recuperação dos fragmentos e de matas ciliares é um obstáculo à sua realização por proprietários rurais. Alternativas que diminuam este custo devem ser desenvolvidas, contribuindo para uma ampla difusão de projetos de recuperação ambiental em propriedades privadas. Os sistemas agroflorestais (SAFs) são associações de espécies agrícolas e florestais. Apresentam-se como alternativa promissora para a recuperação e conservação dos fragmentos florestais. Possibilitam a reprodução dos mecanismos da natureza, garantindo uma produção agrícola/florestal que compensa parte dos custos de implantação de restauração de ecossistemas degradados.

Esta pesquisa discute a recuperação de fragmentos florestais por meio de sistemas agroflorestais. $\mathrm{O}$ projeto se desenvolve em u m fragmento florestal de 86 hectares, situado numa fazenda de produção de cana-de-açúcar, em Piracicaba, São Paulo. Foram testados três tratamentos para recuperação da eco-unidade "capoeira baixa" em áreas de borda e de interior do fragmento: (i) poda dos cipós e sistema agroflorestal, (ii) poda dos cipós e plantio de espécies agrícolas e (iii) testemunha. $O$ sucesso do manejo foi avaliado através da densidade da regeneração de plântulas, riqueza de espécies, crescimento das mudas plantadas, produção das espécies agrícolas, crescimento das árvores pré-existentes e alguns indicadores qualitativos. Os resultados foram animadores, com alta densidade de plântulas recrutadas e alto crescimento das mudas plantadas. A recuperação do fragmento pode ter os custos compensados em parte pela receita da produção, requerendo ainda pesquisas com outras espécies e tipos de manejo. Para que este projeto fosse adequado e acessível ao contexto local, iniciou-se o resgate do conhecimento 
histórico e etnoecológico local, considerando o envolvimento e a relação do proprietário, comunidade de moradores da Fazenda, grupos religiosos e entidades ambientalistas relacionadas com o fragmento. Esta abordagem busca a participação destes atores sociais na procura por soluções para a conservação do fragmento, visando traçar estratégias em parcerias entre os grupos envolvidos. 


\title{
RESTORATION OF A FOREST REMNANT USING AGROFORESTRY
}

\author{
Author: DENISE BITTENCOURT AMADOR \\ Adviser: Prof. VIRGÍLIO VIANA
}

\section{SUMMARY}

The expansion of the agricultural frontier was responsible for promoting deforestation of large areas for monocultures. This fact caused high lands of fragmentation of natural tropical forests. In intensively cultivated landscapes, forests remnants are usually small, isolated and disturbed. However, it is where we find most of the remnant biodiversity. There are increasing evidences that these remnants are not self-sustainable, and require not only protection against antropic disturbances, but active management to conserve their populations. The high cost for recuperation is an obstacle for land owners. New alternatives reducing costs must be developed and can contribute for a wider dissemination of environmental recuperation projects in private properties. Agroforestry systems are forest and agricultural species associations and are a promising management technique for alternative recuperation and conservation of forest remnants, making the reproduction of natural mechanisms possible while promoting production of agricultural crop that can reduce the costs of restoration projects.

This research is about a forest remnant and its recuperation using agroforestry practices. It was developed in an 86 hectares forest remnant, located in a sugar cane farm, at Piracicaba, São Paulo. Three treatments were implanted in "low capoeira" (capoeira baixa) eco-mosaic. These are the most degraded areas in the remnants and are usually covered by vines and lianas, and few trees are found. The studied areas are located in the interior and on the edge of the remnant. The treatments were: (i) pruning of lianas and planting of agricultural and forest species, (ii) pruning of lianas and planting of agricultural species, and (iii) control. The management was evaluated by measuring the density and diversity of tree recruitment, growth of planted trees, agricultural production, growth of pre-existing trees, and some qualitative parameters. The results were promising: high density and diversity of recruitment and high growth of the planted trees. Agricultural production was low, but lowers restoration costs. Further research is needed to find out species and management practices to better pay for costs. To make other projects adequate to this local context, a summary of the etnoecological and 
historical knowledge was surveyed, together with a stakeholder analysis considering the owner, the farm workers community, the religious groups that use the forest for their rituals and local institutions. This approach looks for the participation of "social actors" in search for solutions to remnants conservation, trying to integrate different visions to design strategies that involve social groups. 


\section{CAPÍTULO I INTRODUÇÃO}

"Um dos primeiros atos dos portugueses que chegaram ao Brasil em 1500 foi abater uma árvore para montar a cruz da primeira missa. Nesse gesto premonitório fez-se a primeira vítima da ocupação européia da Mata atlântica, que cobria boa parte do território brasileiro.

Nos cinco séculos que se seguiram, cada novo ciclo econômico de desenvolvimento do país significou mais um passo na destruição de uma floresta de um milhão de quilômetros quadrados, hoje reduzida a vestigios" .Dean, 1996

\section{INTRODUÇÃO}

\section{1 - DESMATAMENTO E FRAGMENTAÇÃO}

No Brasil, o desmatamento vem se dando de forma intensa, provocando sérias alterações na paisagem original, fragmentando a cobertura vegetal e restringindo-a a pequenas áreas remanescentes da vegetação nativa. Este processo de utilização predatória dos recursos naturais, iniciado há 500 anos pelos colonizadores, ganhou maior vulto neste último século, alcançando níveis extremos de perda de áreas naturais. Hoje restam apenas $8 \%$ da cobertura original de Mata Atlântica no Brasil (SOS Mata Atlântica \& INPE, 1993), e a Amazônia segue os mesmos rumos, com um processo de desmatamento desordenado e crescente. $\mathbf{O}$ desmatamento é uma prática antiga, que assolou a grande parte das florestas tropicais, e ainda hoje continua a eliminar as áreas florestais, fragmentando-as ainda mais. $\mathrm{Na}$ legislação ambiental, existe o código florestal que prevê áreas de reserva legal e de preservação permanente em todas as propriedades. No entanto, a legislação não está sendo cumprida devido a falhas no sistema de fiscalização, ausência de programas de conscientização e de políticas públicas e a limitação técnico-científica com a 
escassez de alternativas viáveis economicamente para a recuperação de fragmentos e áreas degradadas e para a revegetação de terras intensamente cultivadas.

O paradigma dominante tem a natureza como mero conjunto de materiais úteis, e um obstáculo para as atividades produtivas, o que distancia o ser humano de seu meio natural e desvincula sua participação dos processos naturais. $\mathbf{O}$ que hoje impera no meio rural são grandes áreas devastadas, com a produção agrícola apoiada no pacote tecnológico da revolução verde, monoculturas utilizando uma série de insumos poluentes, e pequenos fragmentos florestais, isolados e permanentemente perturbados pelas atividades humanas. Este cenário reflete a incoerência e inconsequência das ações do ser humano com seu planeta, conduzindo a uma série de consequências graves, atualmente quase irreversíveis. A transformação dos ecossistemas não pode ser considerada de modo isolado do contexto histórico, social, cultural, político e econômico das populações humanas envolvidas (Vivan, 1998). A maior parte das florestas tropicais encontra-se em países colonizados pelos europeus, que transferiram seu "know-how" sem adaptálo às novas condições ambientais encontradas nos países tropicais. As florestas de clima temperado, onde ocorrem somente algumas dezenas de espécies, foram muito mais estudadas e acabaram sendo por muito tempo o paradigma em termos de estrutura e funcionamento (Kageyama \& Gandara, 1993).

A floresta estacional semidecidual no interior do Estado de São Paulo é um exemplo claro do processo de fragmentação a longo prazo (figura 1). "Já no século XVII, sítios foram abertos onde hoje ficam as cidades de Piracicaba, Botucatu, Rio Claro e outras, por sertanejos racialmente mesclados chamados "caipiras", termo tupi pejorativo que significa "lenhadores da floresta". No século seguinte, o planalto paulista foi sendo transformado em extensas plantações de produtos apreciados pela população das cidades e dos países mais ricos: o café e a cana-deaçúcar. A floresta primária era queimada e derrubada em toda parte onde ocorresse, porque recobria os solos mais férteis. $\mathrm{O}$ cultivo da cana exigia outros produtos da floresta, como lenha para as usinas, madeira de lei para barris de cachaça, caixas para o açúcar e carros de boi. Estas pressões sobre a Mata Atlântica deram início ao que pode ser considerado como danos irreversíveis a paisagens antropomorfizadas" (Dean, 1996). A maior parte da cobertura da Mata Atlântica remanescente está localizada nas montanhas ao longo da costa, permanecendo muito pouco na região de planalto, onde a expansão da agricultura resultou na perda de mais de $95 \%$ de floresta, o que leva a "mata de planalto" a ser considerada um dos ecossistemas mais ameaçados 
do domínio da Mata Atlântica (Viana \& Tabanez, 1996). A região de Piracicaba, por exemplo, tem apenas $2 \%$ de cobertura florestal remanescente, distribuída em fragmentos pequenos, menores de 50 hectares em sua maioria, e muito isolados (Viana et al., 1997b).
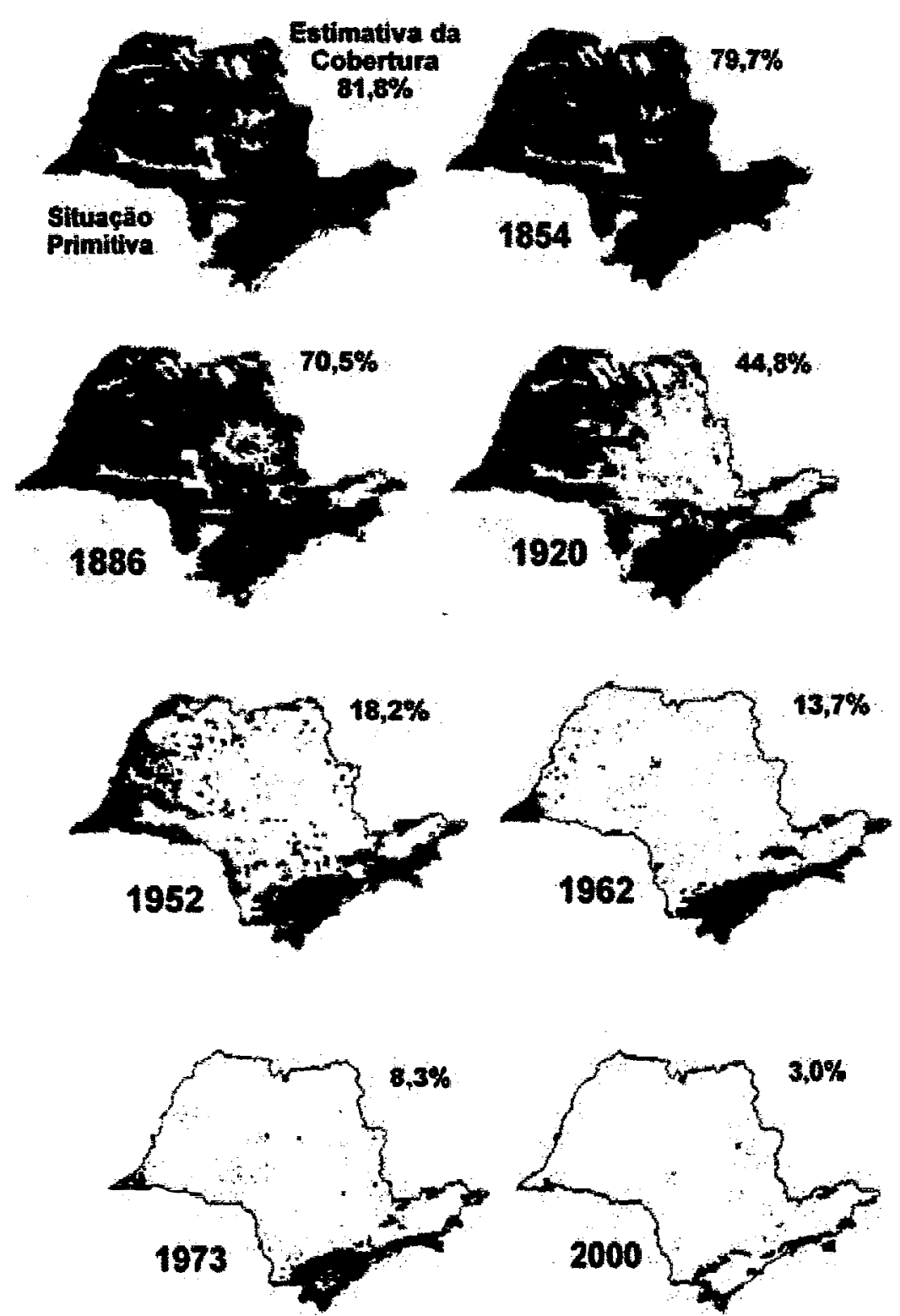

Figura 1. Evolução do desmatamento e fragmentação das florestas no Estado de São Paulo. Fonte: (Victor, 1975). 
Os efeitos do impacto da fragmentação sobre os próprios fragmentos são muitos e não têm sido computados em nível global nas estimativas das taxas de desmatamento das florestas tropicais (Whitmore, 1997). Na floresta amazônica por exemplo, os danos da fragmentação e do efeito de borda foram levantados em 1988 através de imagens Landsat TM, e estimou-se que, de uma área de $6 \%$ da floresta desmatada um total de $15 \%$ foi afetado (Skole \& Tucker, 1993). As consequências do desmatamento são incalculáveis, principalmente numa região biogeográfica onde a riqueza em espécies é das maiores do mundo e existe uma alta taxa de endemismo. Os ecossistemas tropicais envolvem um grande número de espécies, que estão em interações biológicas complexas; a perda de determinada espécie causa implicações em toda a comunidade biológica (Schelhas \& Greenberg, 1996). A imprevidência do ser humano se reflete, por exemplo, na extinção precoce de diversas espécies, fato irreversível na história evolutiva natural.

\section{2 - ECOLOGIA DE FRAGMENTOS FLORESTAIS}

A fragmentação florestal refere-se à redução do tamanho e ao aumento do isolamento em relação a outros remanescentes. $O$ efeito destes fatores desencadeia uma série de transformações nos ecossistemas. As mudanças no microclima, por exemplo, causam impactos determinantes nos fragmentos pelas alterações no fluxo de radiação, vento e água. Uma das características do processo de fragmentação é o empobrecimento dos remanescentes florestais, que passam por um processo gradativo de perda de diversidade biológica e diminuição de suas funções ecológicas (Viana \& Tabanez, 1996; Lucas et al., 1998). A estrutura e a dinâmica de um fragmento florestal são afetadas pelo histórico, tipo e frequência de perturbação, forma do fragmento e relação perímetro-área, efeito de borda, tipo de vizinhança e grau de isolamento (Viana, 1990). 0 tempo de isolamento, a distância entre fragmentos adjacentes e o grau de conectividade são fatores que também determinam as respostas biológicas à fragmentação (Saunders et al., 1991). As alterações na paisagem, relacionadas às atividades de uso da terra, determinam o tipo de matriz de habitats ao redor do fragmento. Sua composição é determinante para a estrutura e dinâmica da biota do fragmento, sendo mais ou menos favorável à conservação pela (i) possibilidade de fluxo gênico de espécies florestais, (ii) fomecimento de habitat para a fauna e (iii) proteção física de extremos climáticos e do fogo (Laurance et al., 1997).

Os impactos climáticos e os efeitos do isolamento promovem "stress" sobre a vegetação. O "stress" pode ser considerado como "um fator que o sistema vive e para o qual não é 
adaptado"; a reação ao "stress" é uma reorganização da vida a curto prazo e adaptação e mutação num período mais longo (Prof. Roelof Oldeman, comunicação pessoal). 0 "stress" desencadeado pelos efeitos da fragmentação florestal acelera o processo de criação de clareiras, promovendo uma dinâmica mais intensa dentro do fragmento. Em florestas muito perturbadas, a distribuição de clareiras pode ser contagiosamente aumentada no espaço e no tempo (Laurance et al., 1997). O processo natural de sucessão nos fragmentos modifica-se profundamente, seguindo uma dinâmica muito diferente das florestas tropicais conservadas. A diversidade e a composição de comunidades de plantas afetam tanto o regime de distúrbios naturais quanto os processos decorrentes destes distúrbios (Denslow, 1995). Desta forma, a modificação da composição de espécies é causa e efeito do processo de degradação ecológica associada à fragmentação florestal. Os individuos interagem com seus vizinhos e podem modificar suas atividades e distribuição (Bazzaz, 1996). A arquitetura das plantas também é afetada com o "stress" e constitui um "feedback" em sistema dinâmico e flexível, em que a arquitetura interfere nos processos e os processos interferem na arquitetura, desenvolvendo elementos e mecanismos para enfrentar o "stress" (Rossignol et al., 1998).

A perda de predadores de topo de cadeia, agentes polinizadores (Murcia, 1995), dispersores de sementes, ciclagem de nutrientes, e agentes em outras interações inter-específicas, provocam alterações em toda a comunidade biológica (Schelhas \& Greenberg, 1996). Nos fragmentos florestais, a comunidade biológica muda em função dos efeitos diretos, com a eliminação de espécies sensiveis às transformações decorrentes da fragmentação e o aumento demográfico de espécies adaptadas às novas condições, e pelos efeitos indiretos decorrentes destas mudanças na comunidade. A fragmentação introduz uma série de novos fatores na história evolutiva de populações naturais de plantas e animais, afetando de forma diferenciada os parâmetros demográficos de mortalidade e natalidade das diferentes espécies e a estrutura e dinâmica de ecossistemas. No caso das espécies arbóreas, a alteração na abundância de polinizadores, dispersores, predadores e patógenos afeta as taxas de recrutamento de plântulas e os incêndios, ventos e mudanças microclimáticas, que ocorrem mais intensamente nas bordas dos fragmentos, alteram as taxas de mortalidade das árvores e dos organismos a elas associados (Viana \& Pinheiro, 1998). 


\section{3 - O $\mathbb{E} F \mathbb{E T O} \mathbb{D E} \mathbb{B O R D A} \mathbb{E}$ A DEGRA DAÇO DOS FRAGMENTOS}

Uma das maiores mudanças decorrentes da fragmentação de habitats é o aumento da proporção de bordas expostas a outros habitats; a importância desta mudança depende do contraste entre o habitat fragmentado e a matriz em que ocorre (Kapos et al., 1997). Nos trópicos, geralmente o contraste é grande e as matrizes são constituídas principalmente por pastagens e monocultivos agrícolas (figura 4), o que toma as paisagens pouco porosas para o fluxo gênico e permanentemente perturbadas pelo manejo das áreas vizinhas com elementos como o fogo e agrotóxicos. A vegetação nas bordas passa a ser afetada por um aumento na intensidade de radiação solar e de ventos, que causa aumento na pressão de vapor, na temperatura do ar e diminuição da umidade do solo (Young \& Mitchell, 1994). Estas alterações, conhecidas como efeito de borda, são variáveis em função do tempo decorrido desde o isolamento do fragmento e de sua orientação cardeal e podem se estender até 100 metros dentro dos fragmentos (Kapos, 1989).

Os fragmentos florestais diferem da floresta original por dois importantes fatores: os fragmentos têm uma maior quantidade de borda e o centro dos fragmentos é mais próximo a uma borda do que nas florestas contínuas (Primack, 1993). Os organismos que estão dentro de um • fragmento ficam expostos às condições diferenciadas dos ecossistemas que os rodeiam. Os efeitos de borda podem ser abióticos, que envolvem mudanças microclimáticas, bióticos diretos, levando à mudanças na abundância e distribuição de espécies, e bióticos indiretos, que acarretam mudanças nas interações entre as espécies (Murcia, 1995).

A escala e a severidade dos danos à floresta variam em função da estrutura e composição de espécies iniciais da floresta, solo, clima, complexidade e resiliência dos processos do ecossistema tais como o fluxo de energia e ciclos biogeoquímicos, a história de perturbação e a persistência e intensidade de "stress" ao ecossistema, que inibe ou reduz os processos naturais de sucessão (Lugo, 1988). A maior parte dos fragmentos de florestas encontra-se abandonada e em acelerado processo de degradação, principalmente com a regeneração natural arbórea limitada pela presença desequilibrada de populações de espécies favorecidas pela modificação no ecossistema. No processo de formação de clareiras e nas bordas dos fragmentos florestais, a dinâmica da sucessão é muito afetada pela colonização de espécies adaptadas às novas condições e eficientes na rápida ocupação de espaços abertos, como as lianas e arbustos decumbentes. A resposta do ecossistema produz uma nova adaptação: é a luta da vida para uma nova ordenação usando a energia do "stress" (Prof. Roelof Oldeman, comunicação pessoal). 
É possível prever algumas mudanças nos fragmentos como a redução do tamanho das populações, algumas espécies excluídas dos fragmentos por não se encontrarem no trecho remanescente no momento do isolamento, a eliminação de espécies que requerem áreas grandes e não sobrevivem nos fragmentos, além de modificações no microclima e nos padrões macroclimáticos locais (Bierregaard et al., 1992). São apontadas como predições para um fragmento florestal em degradação que: (i) o recrutamento de árvores será menor que a taxa de mortalidade, (ii) o efeito de borda vai aumentar com o tempo, (iii) a população de várias espécies será pequena, e (iv) haverá uma estrutura pobre da floresta dominada por eco-unidades pouco diversificadas (Viana et al., 1997b). A sucessão secundária dos fragmentos florestais deve ser melhor compreendida para subsidiar sua recuperação e conservação. A degradação observada nos pequenos e isolados fragmentos florestais da região do planalto ocidental do Estado de São Paulo indicam que a simples proteção não é suficiente para a conservação dos fragmentos (Viana et al., 1997b). Metodologias e estratégias de manejo para recuperação e conservação devem ser pesquisadas e difundidas para estimular a criação de reservas por proprietários de fragmentos.

\section{4 - CONCEITO E DINÂMICA DE ECO-UNIDADES}

O termo "eco-unidade" refere-se a "uma unidade espacial da vegetação que inicia seu crescimento sobre uma superficie bem definida e segue o mesmo processo de desenvolvimento" (Oldeman, 1983b; 1990). As eco-unidades formam os eco-mosaicos que constituem a floresta. “O eco-mosaico é um ecossistema que ocupa uma classe de sítios similares e é composto por vários tipos de eco-unidades que interagem e estão em várias fases de desenvolvimento" (Rossignol et al.,1998) (figura 2). O desenvolvimento das eco-unidades pode ser dividido em quatro fases: inovação, agradação, biostase e degradação, sendo que seus limites são difusos, passando por um gradiente entre uma fase e outra. A fase de inovação ou iniciação é pouco estruturada e muito dinâmica; muita biomassa é produzida por espécies "inovadoras" ou iniciais, principalmente herbáceas, lianas, plântulas de árvores e rebrota de árvores pré-existentes. A agradação é a fase de estruturação, o dossel se fecha por conjuntos de espécies estruturais que filtram as influências externas; porém, muitas vezes esta fase é bloqueada ou retardada pelo grande desenvolvimento de lianas. Nesta fase, os organismos decompositores são numerosos e ativos. Na biostase, ou fase madura, a eco-unidade está mais claramente organizada, com grupos de árvores do presente estruturando, ordenando e oferecendo diversos biótopos para outros organismos. Ecossistemas de 
diversos tamanhos e formas de vida marcam esta fase. Na fase de degradação, a arquitetura da floresta é "quebrada", dissolvida em diversas eco-unidades menores, constituindo a preparação para a próxima reocupação da fase de inovação, que pode ser lenta ou rápida dependendo do processo que a detona (Oldeman, 1990; Rossignol et al., 1998).

\section{BIOSFERA}

Maior sistema, composto por todos biomas em interação $\Downarrow$

\section{BIOMA}

Eco-complexo de eco-complexos em interação. Seu tamanho é definido por zonas bioclimáticas. $\Downarrow$

\section{ECO-COMPLEXO}

Ecossistema de ecossistemas, formado por vários eco-mosaicos em interação que criam propriedades emergentes.

\section{$\Downarrow$}

\section{ECO-MOSAICO}

Ecossistema que ocupa uma classe de sítios similares. Composto por vários tipos de eco-unidades que interagem e estão em várias fases de desenvolvimento.

$$
\Downarrow
$$

ECO-UNIDADE

Unidade espacial da vegetação que inicia crescimento sobre uma superficie bem definida, seguindo o mesmo processo de desenvolvimento.

$$
\Downarrow
$$

\section{ORGANISMOS}

Indivíduos : vegetais, animais, fungos e bactérias.

$\Downarrow$

\section{COMPARTIMENTOS}

Órgãos e partes constituintes dos seres vivos.

Figura 2. Hierarquia dos sistemas orgânicos e suas definições. (baseado em Oldeman, 1983b; 1990 e Rossignol et al., 1998).

A hierarquia básica definida pela estrutura dos sistemas é muito útil por ser diretamente ligada ao tempo e espaço, constituindo uma base para sistemas multi-dimensionais (Oldeman, 1990). Os niveis dos sistemas orgânicos podem ajudar a explicar as mudanças biológicas em resposta ao "stress". Cada nível é muito próximo a outro e tem interações com sistemas do mesmo nível ou de outros níveis hierárquicos, sendo que os limites são difusos (Rossignol et al., 1998).

Dois processos caracterizam os movimentos na dinâmica das eco-unidades: a fragmentação e a fusão. As eco-unidades fragmentam-se naturalmente, originando eco-unidades 
ainda menores a partir de características próprias como tipo de vizinhança, mancha de solo, topografia e posição. Os padrões de fragmentação de eco-unidades diferem pelos impactos ambientais sobre os ecossistemas que são desiguais quanto à energia, tempo e espaço. Seus componentes, por sua vez, diferem em : (i) constituição genética e suas respostas ao "stress", (ii) expectativa de tempo de vida, e (iii) taxa de crescimento (Rossignol et al., 1998). As eco-unidades freqüentemente se subdividem, formando um modelo de fractais com padrões similares que se repetem em diferentes escalas (Oldeman, 1992). A fusão de eco-unidades é o processo que dinamiza as transformações do eco-mosaico, homogeneizando padrões do dossel sob um mesmo regime de impacto ambiental. A fusão das eco-unidades transforma um eco-mosaico, com diversas eco-unidades, em uma "eco-unidade funcional". Os movimentos de fusão e fragmentação representam um balanço da transferência de funções entre os níveis de eco-mosaico e eco-unidade.

Existe uma transição entre uma eco-unidade e outra que forma nichos específicos com características florísticas e fisionômicas das eco-unidades que se avizinham. Estes gradientes de interação devem-se às interferências ecológicas. Quanto menor o tamanho das eco-unidades, mais íntimo é o contato entre elas e, portanto, maior a interação. $O$ limite é difícil de determinar, e qualquer tentativa neste sentido limita sua compreensão, pois separa o sub-sistema de seu sistema (Vester, 1997). $O$ conceito de eco-unidades e mosaicos silváticos constituindo florestas ilustra a interação dos "retalhos", onde o limite não é visível e há um gradiente entre as eco-unidades. Assim, qualquer intervenção deve considerar a heterogeneidade, os limites imprecisos e a constante transformação das eco-unidades.

Neste trabalho, os fragmentos florestais são considerados eco-complexos, constituídos por eco-mosaicos que agregam as eco-unidades. Esta concepção representa a evidência dos resultados obtidos que expressam a dinâmica e heterogeneidade entre os níveis hierárquicos dos sistemas. Em alguns fragmentos de floresta estacional semidecidual foram caracterizados quatro tipos de ecomosaicos, que, a partir da fusão das eco-unidades que os formam, transformaram-se em "ecounidades funcionais", apresentando padrões no dossel sob um mesmo regime de impacto ambiental. Foram identificados a partir de características estruturais e são denominados: capoeira baixa, capoeira alta, bambuzal e mata madura (Tabanez, 1995). A capoeira baixa (figuras 3 e 5) é semelhante a clareiras, sem ou com poucas árvores, geralmente cobertas por cipós e arbustos decumbentes, com dossel baixo, descontínuo e alta insolação. Apresenta geralmente baixa ou nula 
regeneração de espécies arbóreas de qualquer estágio sucessional. A capoeira alta tem dossel descontínuo entre 10 e 15 metros de altura e presença de cipós no sub-bosque e na maioria dos indivíduos arbóreos. O bambuzal é caracterizado por domínio de espécies de bambu e baixa densidade de indivíduos arbustivos e arbóreos, e a mata madura caracteriza-se por ser o mosaico mais desenvolvido, com dossel contínuo a 20-25 metros de altura e presença de indivíduos emergentes. Cipós ocorrem em baixa densidade e no sub-bosque há um grande número de arvoretas de espécies típicas deste ambiente (Tabanez, 1995).

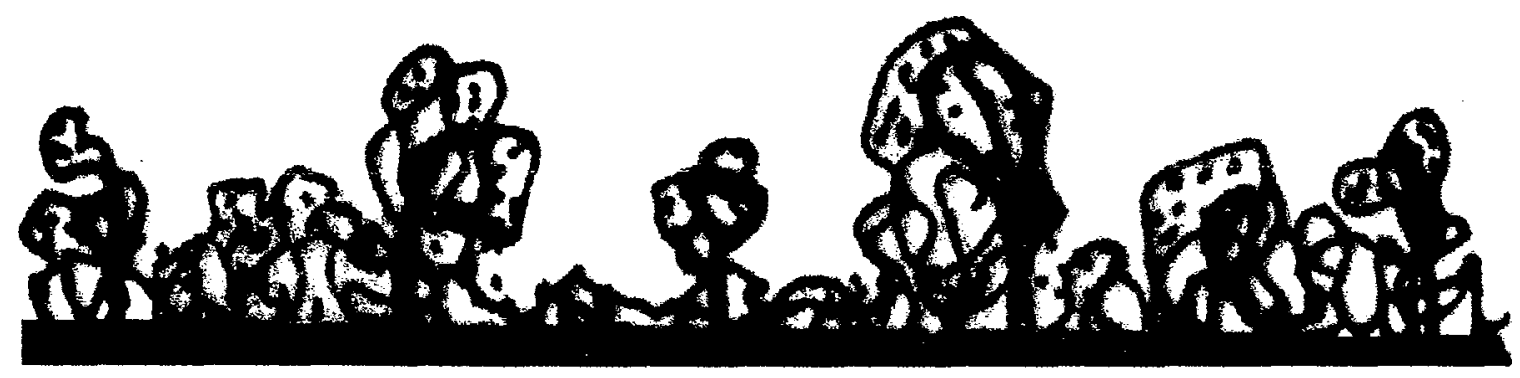

Figura 3. Perfil esquemático de capoeira baixa com poucas árvores e alta densidade de cipós formando um manto contínuo de vegetação(Oldeman, não publicado).

A partir do levantamento dos tipos de eco-mosaicos e suas proporções em percentagem no fragmento Capuava (tabela 1) em Piracicaba, São Paulo, verificou-se um alto nível de degradação, com grande percentual de capoeira baixa e capoeira alta.

Tabela 1. Percentual de tipos de eco-mosaicos no fragmento Capuava. (baseado em Tabanez, 1995)

\begin{tabular}{|l|l|l|l|}
\hline \multicolumn{4}{|l|}{ ECO-MOSAICOS } \\
\hline Capoeira baixa & Capoeira alta & Bambuzal & Mata madura \\
\hline $24,19 \%$ & $65,05 \%$ & $6,56 \%$ & $4,20 \%$ \\
\hline
\end{tabular}

A estimativa da proporção dos estágios das eco-unidades num mosaico de vegetação pode ser utilizada como parâmetro para diagnosticar o nível de degradação/conservação desta vegetação (Nascimento, 1998) e indicar estratégias diferenciadas de intervenção para recuperação, apontando práticas de manejo localizadas para auxiliar a sucessão. 


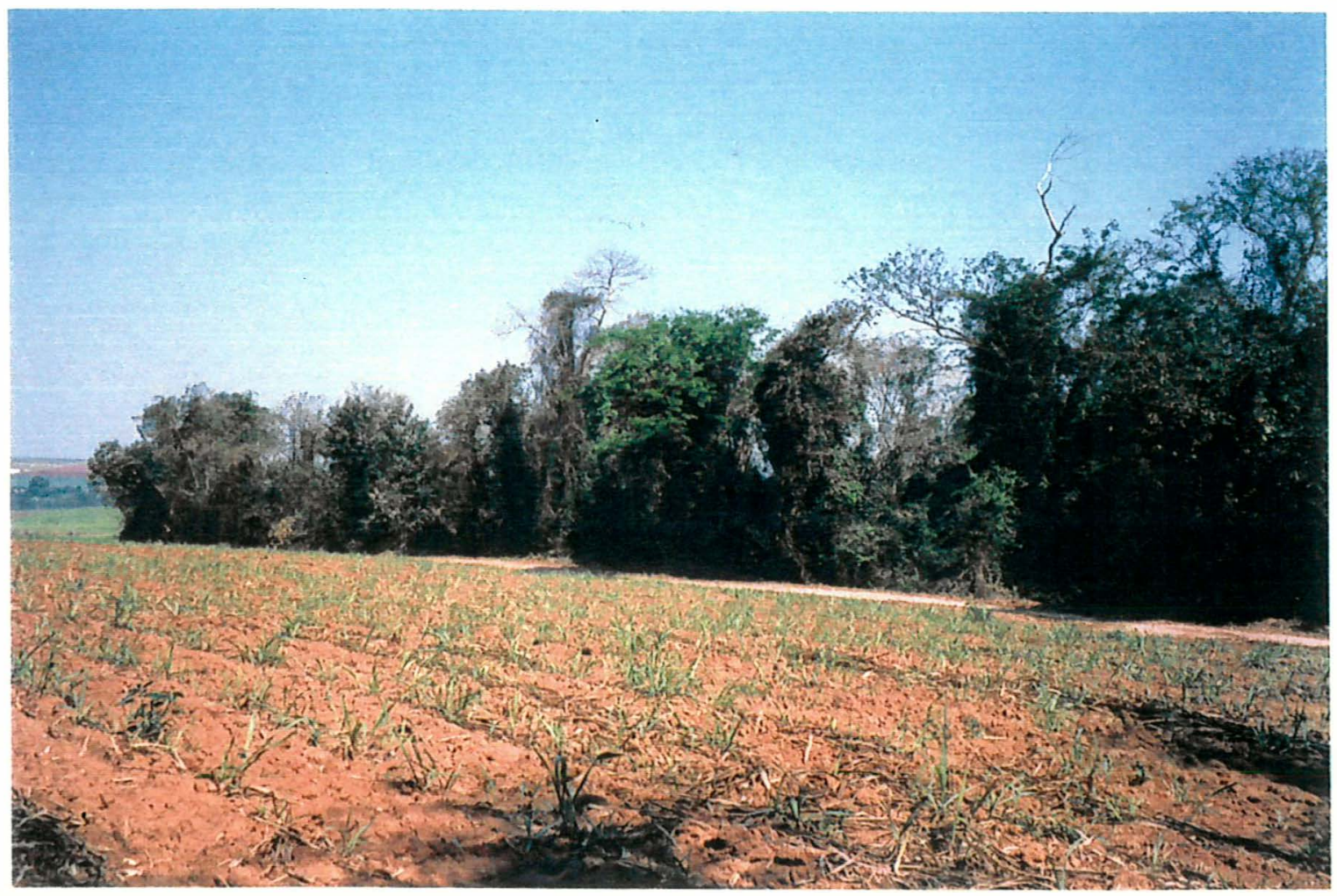

Figura 4. Interface do fragmento Capuava com a matriz: a cultura da cana-de-açúcar.

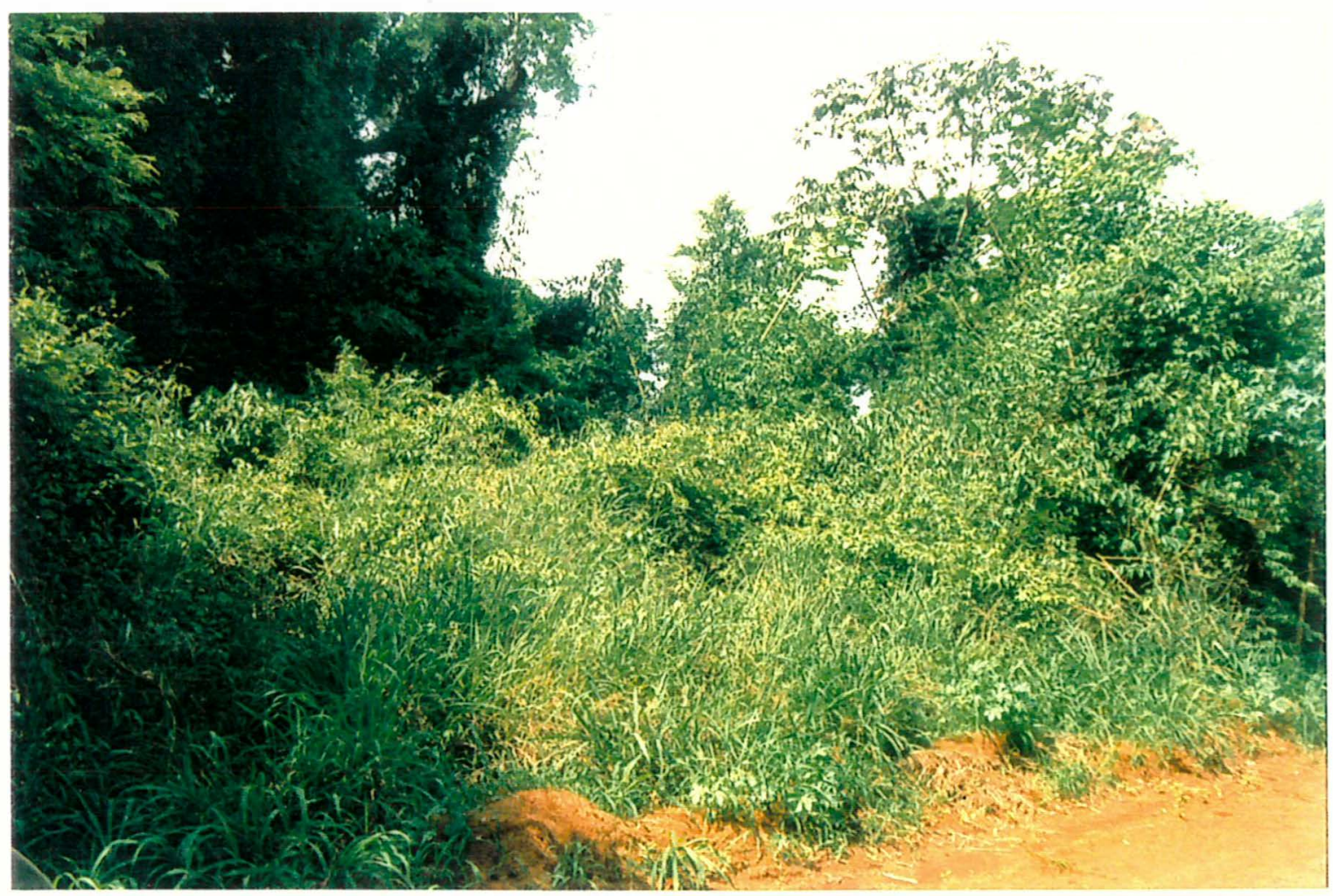

Figura 5. Eco-mosaico "capoeira baixa" na borda do fragmento Capuava. 


\section{5 - A RECURERAÇÃO DE FRA GMENTOS FLORESTAIS}

Partindo da constatação de que os fragmentos pequenos e isolados da floresta de planalto do interior de São Paulo não são auto-sustentáveis (Viana, 1992), faz-se necessário desenvolver alternativas de recuperação florestal, contribuindo para o desenvolvimento de estratégias de conservação na região. 0 manejo de ecossistemas fragmentados tem dois componentes básicos: (i) o manejo da dinâmica interna dos fragmentos e (ii) o manejo das influências externas ao sistema natural (Saunders et al., 1991). Para a efetiva recuperação dos fragmentos florestais degradados é necessária a interrupção dos eventos que contribuem para a degradação e a adoção de procedimentos de manejo adequados à situação. Numa analogia ao ser hurnano, as atitudes preventrvas garantem a saúde e as práticas de recuperação tratam a doença, no caso a degradação. Há uma escassez de pesquisas em tecnologias para a restauração de fragmentos florestais tropicais (Janzen,1988), representando um grande desafio por aliar a necessidade do conhecimento ecológico à viabilidade de aplicação e execução.

Uma vez definida a extensão da degradação, a decisão do manejo é feita podendo-se optar pela (i) restauração à condição original, (ii) reabilitação de certas condições originais e, possivelmente, algumas não originais, (iii) desenvolvimento de um ecossistema alternativo ou (iv) abandono ou recuperação natural (Caims, 1986). As definições de cada tipo de manejo para a recuperação de ecossistemas degradados representam formas distintas para a abordagem da questão e a diversidade de condições e objetivos. Estas definições vêm sendo utilizadas com significados variáveis, trazendo à tona uma rica discussão sobre os métodos e objetivos da recuperação, restauração e reabilitação.

A "Society for Ecological Restoration" define a restauração como o restabelecimento de um ecossistema considerado histórico, visando a volta da estrutura, diversidade e dinâmica deste ecossistema. A restauração stricto sensu segue esta definição e a lato sensu qualifica o fato de freiar a degradação e tentar prioritariamente o restabelecimento das funções essenciais e a estrutura geral do ecossistema pré-existente (Le Floc'h \& Aronson, 1995). O brilhantismo da restauração ecológica é a fusão do conhecimento prático e teórico, devendo partir de uma abordagem holística (Higgs, 1994).

A reabilitação de um ecossistema consiste em lhe permitir encontrar suas funções essenciais através de uma intervenção drástica mas limitada no tempo, com o objetivo, comum à restauração, de restabelecer ecossistemas autônomos capazes de auto-reparação (resiliência) 
perante perturbações (Le Floc'h \& Aronson, 1995). A reabilitação dos ecossistemas florestais pode se dar através da facilitação, aceleração e direção dos processos sucessionais naturais (Parrota, 1993).

Neste trabalho buscamos a recuperação de eco-mosaicos degradados de um fragmento através de práticas de manejo que priorizaram o resgate da função do ecossistema, entendendo que a partir da reabilitação dos mecanismos funcionais naturais, a floresta tem capacidade de resiliência e pode se restruturar. A restauração é considerada uma meta, a reabilitação é o caminho e a recuperação é a ação imediata. A recuperação da função do ecossistema através da rápida formação de uma cobertura florestal auxilia, muitas vezes, a restauração do ecossistema a longo prazo e o resgate da biodiversidade original (Jesus, 1992).

A recuperação florestal a partir da regeneração natural é indicada para locais onde existe nas proximidades uma floresta remanescente, de modo que os processos naturais possam agir (Crestana, 1993). As áreas degradadas dentro dos fragmentos florestais têm à sua volta indivíduos arbóreos adultos que são matrizes para dispersão de propágulos. 0 manejo baseado no controle de cipós, por exemplo, mostrou-se bastante eficaz para a recuperação de capoeiras baixas em um fragmento ao permitir o recrutamento de maior número de espécies arbóreas, auxiliando a sucessão (Tabanez, 1995).

0 manejo para recuperação de fragmentos florestais deve considerar o estado de degradação/conservação em que se encontram e a matriz onde estão localizados. Cada situação é única e requer caminhos específicos, determinados a partir das necessidades e dos objetivos locais. Como a composição da matriz em volta do fragmento exerce um papel determinante na estrutura e dinâmica da sua biota (Laurance et al., 1997), é fundamental o planejamento da paisagem de forma integrada para a efetiva recuperação do fragmento. A situação de cada matriz de vegetação apresenta locais prioritários para a restauração como : margens de rios, remanescentes degradados, bordas de fragmentos, corredores ligando fragmentos, ilhas, habitats para determinadas espécies e a matriz degradada entre fragmentos (Lamb et al., 1997).

É importante testar a viabilidade de altemativas para recuperação de fragmentos que apresentem um baixo custo de implantação e adequação às condições sócio-econômicas, culturais e ambientais locais. As pessoas relacionadas e os grupos de interesse têm grande importância na conservação dos fragmentos e podem ser agentes para a efetiva recuperação da paisagem. 


\section{6 - SISTEMAS AGROFLORESTAIS}

Sistema agroflorestal é um novo nome para práticas antigas, desenvolvidas em grande parte por comunidades tradicionais em várias partes do mundo. Há uma grande ambiguidade e muitas definições para sistemas agroflorestais. A definição adotada pelo ICRAF (Intemational Center fơ Research in Agroforestry) é : "Sistema agroflorestal é um nome coletivo para sistemas e tecnologias de uso da terra onde lenhosas e perenes são usadas deliberadamente na mesma unidade de manejo da terra com cultivares agrícolas e/ou animais em alguma forma de arranjo espacial e seqüência temporal" (Nair, 1993). O conceito básico vem evoluindo em função dos níveis de complexificação dos sistemas e da necessidade de posicioná-los frente à legislação. Estes sistemas apresentam um grande potencial para a efetividade da restauração ecológica aliada à viabilidade econômica, favorecendo a adoção por grande número de proprietários rurais.

Os sistemas agroflorestais exercem um importante papel perante as necessidades dos países tropicais em desenvolvimento ao criar uma interface entre agricultura e floresta. Representam um grande potencial para o desenvolvimento com base nas potencialidades dos sistemas agrícolas e/ou florestais e exercem maior estabilidade ecológica ao conservar e melhor aproveitar os recursos pelo gradiente arquitetônico e fisiológico dos componentes do sistema. De acordo com as características ecológicas das espécies é possível criar consórcios e eco-unidades e dirigir a sucessão secundária ao invés de combatê-la, no processo de composição e desenvolvimento do sistema. 0 conceito de sistema agroflorestal deve ter como paradigma a dinâmica e a biodiversidade dos ecossistemas naturais (Götsch, 1995). As agroflorestas são povoamentos permanentes, similares às florestas nativas, com composição bastante diversificada e estratificada. Assemelham-se a florestas de uso múltiplo, diferenciando-se destas pela presença de espécies agrícolas em algum momento (Dubois, 1996).

É no contexto de reavaliação da revolução verde, do papel da atividade florestal e na busca de altemativas para o desenvolvimento rural sustentável que se insere a história recente das investigações científicas em sistemas agroflorestais (Viana et al., 1997a). As maiores ênfases nas pesquisas e na implantação de agroflorestas têm se dado em: melhoria das capoeiras em pousio (agricultura itinerante), melhoria da fertilidade do solo, produção de alimentos, conservação do solo, manejo da água e proteção de espécies raras (Nair, 1993). O aprimoramento dos Sistemas agroflorestais já existentes e o desenvolvimento de novos é um dos maiores desafios para todos aqueles que se interessam pelo desenvolvimento sustentável de regiões tropicais (FAO, 1991). 
Existem poucas experiências com agroflorestas para recuperação ambiental, tanto em áreas degradadas como em fragmentos florestais ou matas ciliares. Os sistemas agroflorestais, pela aproximação em estrutura e diversidade dos ecossistemas naturais, representam um grande potencial como estratégia metodológica para a recuperação de áreas degradadas, matas ciliares, bordas de fragmentos e implantação de corredores entre fragmentos, possibilitando o retomo econômico do investimento em projetos de recuperação florestal. O sistema "Taungya" é um exemplo tradicional da Ásia, desenvolvido para diminuir o custo do estabelecimento de florestas plantadas, onde as espécies florestais são plantadas junto a cultivos agrícolas de ciclo curto e a receita gerada pela produção agrícola paga o custo de implantação do sistema (MacDicken \& Vergara, 1990).

Os sistemas agroflorestais despontam como uma opção concreta para a busca de um modelo de desenvolvimento não predatório, que tenta resolver a "contradição" entre conservação da natureza e desenvolvimento ao viabilizar a coexistência do ser humano com o meio ambiente de forma sustentável social, econômica e ecologicamente. 0 desenvolvimento sustentável busca conciliar a satisfação da necessidade do presente sem comprometer a habilidade das gerações futuras em garantir o suprimento de suas necessidades através da manutenção da integridade da arquitetura e dos processos, ritmos e ciclos da natureza.

\section{7 - MÉTODOS PARTICIPATIVOS}

Os fragmentos florestais do Estado de São Paulo estão, de maneira geral, nas mãos de proprietários privados, e o futuro deles depende em muito da decisão desses proprietários e das comunidades locais (Viana, 1995). O envolvimento dos proprietários, pessoas e instituições relacionadas aos fragmentos florestais pode contribuir para a busca de estratégias factiveis para sua recuperação. Como este trabalho busca fornecer subsídios para o desenvolvimento de metodologias que viabilizem a recuperação de fragmentos florestais a um custo baixo e sejam adequadas ao contexto sócio-econômico em que se inserem, optou-se por envolver os atores sociais relacionados ao fragmento em estudo nesta pesquisa.

Há uma carência no meio científico/acadêmico de ações concretas no mundo real, além da necessidade de uma melhor compreensão dos fenômenos estudados dentro do contexto sócioambiental. A partir desta constatação, emergem em diversos campos do conhecimento os processos de pesquisa participativa, pesquisa-ação e outras modalidades que partem de uma 
mesma abordagem, buscando a participação dos atores envolvidos na situação da investigação. 0 conhecimento acadêmico combinado com o conhecimento e sabedoria popular pode resultar em un conhecimento científico total, de natureza revolucionária, com uma imagem mais precisa e correta da realidade (Remmers, 1998). Ao colher as informações de forma participativa, o público envolvido torna-se sujeito do ato de conhecer e de transformar e participa da produção deste conhecimento, tomando posse dele (Brandão, 1981).

A participação foi definida como "um processo pelo qual os grupos envolvidos influenciam e partilham o controle sobre as iniciativas, decisões e recursos do desenvolvimento que os afeta" e envolve mudanças e transferências de poder (Nelson \& Wright, 1995). Existem niveis distintos de participação, dependendo do grau de envolvimento dos participantes com o objeto e os objetivos do trabalho e da própria dinâmica e metodologia aplicadas. Os níveis de participação vão dos mais ativos aos mais passivos, mas sempre garantem maior legitimidade aos trabalhos desenvolvidos.

Dinâmicas como as utilizadas em diagnósticos rápidos e participativos em agroecossistemas têm se mostrado altamente eficientes pela flexibilidade, adaptação às realidades locais e caráter aproximativo de conhecimento da realidade (Petersen, 1996). Diversas técnicas podem ser citadas como instrumentos metodológicos para a realização destes tipos de diagnóstico, entre elas : (i) perfil histórico, utilizado como auxiliar para entender mudanças passadas no âmbito ambiental e social, (ii) mapeamentos participativos, muito importantes para identificar padrões de uso da terra e noções espaciais, (iii) entrevistas semi-estruturadas, tipo de entrevista no qual apenas algumas questões são pré-determinadas, sendo a maior parte das perguntas colocadas no transcurso da própria entrevista, e (iv) matriz de critérios e opções, utilizada para descobrir o quanto de um tópico é conhecido localmente e quais são as prioridades sobre ele. Estas dinâmicas representam algumas das que vêm sendo utilizadas e buscam a participação dos envolvidos através de propostas lúdicas para a discussão.

O ambiente reflete os caminhos sócio-culturais e econômicos do meio envolvente a partir das interações, ações e relações do Universo humano com o natural. Muitas pessoas afetam e são afetadas pelas transformações dos recursos naturais. $\mathbf{O}$ conhecimento local dos recursos naturais vem sendo reconhecido pelo seu valor ecológico e é um assunto para maior atenção científica (Shanley et al., 1997). A restauração ecológica deve estar aliada à restauração bio-cultural (Janzen, 1986) e para isso é importante buscar a conscientização e participação das pessoas 
envolvidas. 0 estudo-ação busca não apenas conhecer a realidade, mas também transformá-la, com a recuperação crítica da história e a restituição sistemática e enriquecida do conhecimento popular (Fals Borda, 1991). O cientista de hoje deve estar compromissado com o que afeta o presente e o futuro da humanidade, usando a ciência como ferramenta crítica para a mudança social. 


\section{8 - O PRORLEMA $\mathbb{D E}$ PESQUHSA}

A conservação de fragmentos florestais sugere a necessidade da interrupção dos eventos de degradação e a adoção de práticas de manejo para recuperação. Estas práticas, para serem amplamente aplicadas, devem apresentar baixo custo, promover a recuperação estrutural e funcional do fragmento, conservar a biodiversidade, adequar-se às características sócio-culturais do local e envolver os atores sociais relacionados.

\section{9 - HIPÓTESES}

(i) Os sistemas agroflorestais facilitam a sucessão secundária em eco-mosaicos degradados de fragmentos florestais.

(ii) Os sistemas agroflorestais, como estratégia para recuperação de fragmentos, apresentam vantagens em relação às técnicas convencionais de recuperação florestal : econômicas, pela compensação dos custos, e sociais, com maior possibilidade de participação das pessoas e dos grupos envolvidos.

\subsection{0 - PREDIÇÕES}

(i) O manejo com sistemas agroflorestais facilita a dinâmica da sucessão secundária em eco-mosaicos degradados de fragmentos florestais por possibilitar maior densidade e diversidade de regeneração de espécies nativas em função do controle dos cipós e arbustos decumbentes, estímulo à germinação do banco de sementes através do revolvimento do solo no plantio e pelo enriquecimento da diversidade biológica através da introdução de espécies arbóreas.

(ii) $\mathrm{O}$ custo da recuperação de fragmentos florestais através de sistemas agroflorestais é mais baixo do que o custo de sistemas convencionais de recuperação florestal por apresentar compensação financeira com o retorno econômico da produção agrícola. 


\title{
CAPÍTULO II
}

\section{SISTEMAS AGROFLORESTAIS PARA RECUPERAÇÃO DE CAPOEIRAS BAIXAS DE UM FRAGMENTO FLORESTAL}

\author{
"Sistemas agroflorestais devem ter como paradigma \\ a dinâmica e a biodiversidade dos ecossistemas naturais" \\ Ernst Götsch, 1995.
}

\section{INTRODUÇÃO}

A fragmentação florestal é um fenômeno associado com a expansão da fronteira agrícola e tem recebido maior atenção ultimamente devido às elevadas taxas de desmatamento e seus consequentes efeitos em regiões tropicais. A floresta estacional semidecidual do interior do Estado de São Paulo encontra-se, em sua maior parte, em paisagens dominadas pela agricultura intensiva, formando fragmentos pequenos e muito isolados. Estes fragmentos são fruto de um processo histórico de desmatamento para uso da terra em atividades agrícolas e exploração madeireira e sofrem intensas perturbações de origem antrópica com incêndios periódicos, caça e agrotóxicos advindos de práticas agrícolas em seu entomo. A elevada proporção de ambientes de borda em relação aos de interior, o alto grau de isolamento, as paisagens de baixa porosidade em que se situam e o histórico de perturbações intensas tornam as populações de espécies florestais altamente vulneráveis a processos de extinção local (Viana \& Pinheiro, 1998). A degradação observada nos fragmentos florestais indica que não são auto-sustentáveis e que a simples proteção não é suficiente para sua conservação (Viana et al., 1997b).

Grande parte dos remanescentes de floresta (74\%) na região do planalto ocidental paulista situa-se em propriedades privadas e está geralmente muito vulnerável a distúrbios contínuos 
(Viana \& Tabanez, 1996). Desta forma, faz-se necessário desenvolver altemativas para a recuperação e a conservação dos fragmentos com o envolvimento dos atores-chaves : proprietários, grupos, pessoas e instituições relacionadas à floresta, possibilitando traçar estratégias coerentes e viáveis para a atuação e o manejo conservacionista. $O$ cenário atual de paisagens extremamente retalhadas, com fragmentos pequenos, isolados, perturbados e degradados sugere uma urgência de pesquisas e ações em recuperação ambiental, antes que o nível de degradação seja tal que o processo seja irreversível.

A teoria da sucessão tem um papel importante na definição de estratégias para a preservação, manejo, reabilitação e restauração dos ecossistemas (Bazzaz, 1996). As práticas de recuperação de fragmentos florestais visam facilitar os processos da sucessão natural, restabelecendo a estrutura e composição da floresta através da regeneração natural (Tabanez, 1995). Otimizar os mecanismos naturais de regeneração pode auxiliar e acelerar a sucessão, que em ambientes degradados tem seu processo limitado. Além da regeneração natural, o plantio de enriquecimento pode auxiliar a recuperação quando plantadas espécies de rápido crescimento que criam ambiente propício para outras espécies.

Os sistemas agroflorestais conduzem a sistemas em que plantas de espécies agrícolas são combinadas com espécies arbóreas sobre a mesma unidade de manejo da terra (Nair, 1993). Existem, entre as plantas, interações ecológicas e econômicas, podendo-se combiná-las de forma complementar e sinérgica. A maior parte dos trabalhos científicos e práticos com sistemas agroflorestais são sistemas de produção em que a utilização das árvores objetiva benefícios sobre o solo e as culturas além de produção a longo prazo, visando um rendimento contínuo e sustentável. Existem poucas experiências com sistemas agroflorestais para recuperação de áreas e/ou florestas degradadas. Neste trabalho, os sistemas agroflorestais são utilizados como princípio para a recuperação de um ecossistema : as "capoeiras baixas", eco-mosaicos degradados de fragmentos florestais. Desta forma, o objetivo não é a produção contínua de produtos agrícolas, mas a compensação dos custos da restauração através da produção nos primeiros anos para viabilizá-la economicamente, sendo auto-financiada pela sua própria produtividade.

A comparação com o ecossistema natural local é útil para o planejamento de agroflorestas e o critério pode ser a arquitetura e a dinâmica de crescimento da floresta nativa (Oldeman, 1983a). Hart (1980) propôs o uso de dois conceitos para o planejamento de sistemas de produção sucessionais : a "analogia" para buscar as similaridades na estrutura e dinâmica das populações 
entre sistemas naturais e antrópicos, e a "transformação", que é efetuada pela reposição de espécies nativas por espécies úteis preenchendo o mesmo nicho funcional e estrutural que as nativas precedentes. Os conceitos são complementares e podem ser usados para propósitos distintos em agroflorestas. Quando manejadas de acordo com as estratégias da natureza, as espécies cultivadas são plantadas em consórcios com espécies arbóreas plantadas e/ou nativas, e as associações de plantas se sucedem umas às outras no processo dinâmico e contínuo da sucessão natural (Götsch, 1995).

Este trabalho de pesquisa tem como objetivo testar na prática a aplicação de conceitos agroflorestais como estratégia para recuperação de eco-mosaicos degradados em um fragmento florestal. As hipóteses prevêem a facilitação da sucessão secundária através das práticas de manejo, a compensação do custo da recuperação pela produção agrícola e a adequação da proposta ao contexto social.

\section{MATERIAL E MÉTODOS}

\section{1 - ÁREA DE ESTUdO}

A pesquisa foi realizada em um fragmento de floresta estacional semidecidual no município de Piracicaba, na região central do Estado de São Paulo. As coordenadas aproximadas do município são $2243^{\prime} \mathrm{S}$ e $4725^{\prime} \mathrm{W}$, e sua altitude 580 metros. O clima da região é do tipo Cwa pelo sistema de Köppen, mesotérmico ou subtropical úmido, com invemo seco. A pluviosidade média anual é de $1247 \mathrm{~mm}$ (período de 1917 a 1985), porém de abril a setembro (seis meses) a pluviosidade é menor que $100 \mathrm{~mm}$ (Tabanez, 1995). As formações vegetais naturais da região são: floresta estacional semidecidual ou floresta mesófila semidecídua, cerrado e floresta de várzea (IBGE, 1992). A floresta estacional semidecidual tem em sua composição florística influência da Mata Atlântica, da floresta amazônica e dos cerrados (Leitão Filho, 1987). Os remanescentes de floresta ocupam atualmente apenas cerca de $2 \%$ da região ao redor do município (Tabanez et al., 1994). A região da Bacia do Piracicaba, localizada na depressão periférica do Estado de São Paulo, é cenário do intenso povoamento, industrialização, cultivo e deflorestamento, e hoje sofre graves impactos ambientais como a perda da qualidade da água, a diminuição da biodiversidade e a exaustão e degradação do solo pelo monocultivo, principalmente com a cultura da cana-de-açúcar (Secretaria de Meio Ambiente, 1994).

O fragmento em estudo localiza-se na Fazenda Capuava, no município de Piracicaba, a 
cerca de $15 \mathrm{~km}$ do centro da cidade, às margens da rodovia SP-127 (Piracicaba-Rio Claro). Sua área é de 86 hectares, coberta por floresta densa de dossel bastante irregular e o solo é do tipo latossolo vermelho. Seu formato é alongado, sua vizinhança é a cultura da cana-de-açúcar, encontra-se isolado de outros fragmentos (figura 6) e sofreu extração madeireira até a década de 60. A área com cobertura florestal na fazenda reúne este fragmento e outros menores, representando $15 \%$ da propriedade.

A fazenda Capuava possui área total de 1007 ha e sua produção é voltada para a canade-açúcar desde 1886 e, em menor escala, girassol em áreas de rotação de cultura e eucalipto. Possui uma usina para a produção de aguardente para exportação e conta com 140 trabalhadores permanentes e trabalhadores temporários na época de colheita da cana. Na propriedade existe uma colônia onde moram 54 famílias de trabalhadores da Fazenda, dois mercados, uma Igreja católica e uma escola, que foi recentemente desativada.

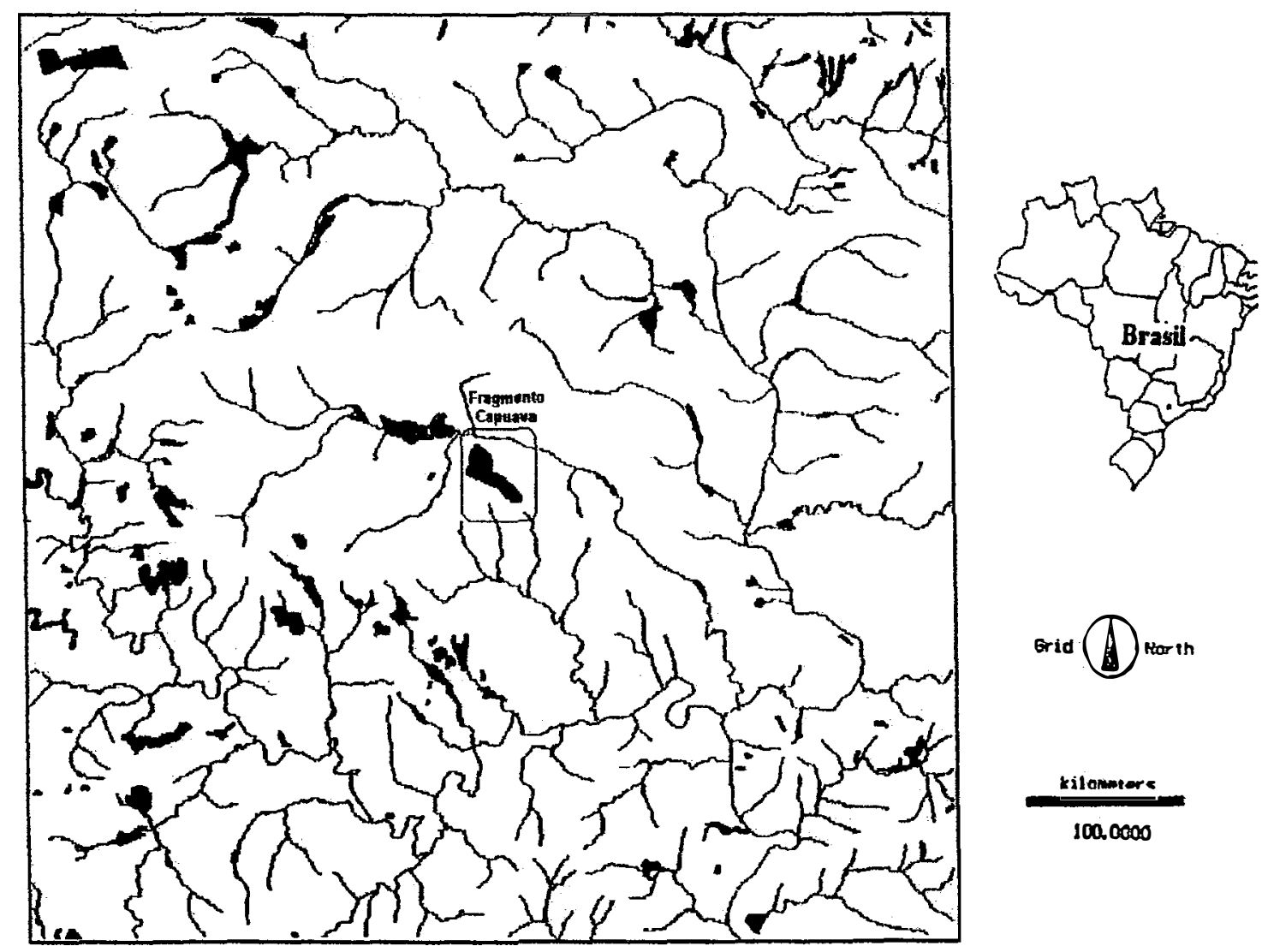

Figura 6. Fragmentos florestais da região de Piracicaba, SP (adaptado de Viana et al., 1997b). 


\section{2 -DESENHO EXPERIMENTAL}

A recuperação das áreas de capoeira baixa do fragmento florestal foi testada utilizando o sistema agroflorestal como princípio e técnica. O manejo visou facilitar e otimizar os mecanismos naturais da sucessão através do controle de lianas e arbustos decumbentes em desequilíbrio populacional, favorecendo a regeneração arbórea natural, e com a introdução de espécies cumprindo papel econômico e ecológico na recuperação estrutural e funcional do fragmento.

0 experimento foi instalado em capoeiras baixas nas bordas (aproximadamente $10 \mathrm{~m}$ das bordas) e no interior (a partir de $50 \mathrm{~m}$ das bordas) do fragmento. Em ambas as situações, as áreas apresentaram fisionomia, estrutura e dominância de espécies invasoras similares. Observa-se, portanto, que as causas para as distintas situações são variáveis.

Três tratamentos foram aplicados :

Tratamento 1 : Controle dos cipós e plantio agrícola - poda dos cipós e plantio de sementes de espécies agrícolas;

Tratamento 2 : Controle dos cipós e plantio agroflorestal - poda dos cipós e plantio de mudas de espécies arbóreas e sementes de espécies agrícolas;

Tratamento 3 : Testemunha - nenhuma intervenção.

Nas áreas com o tratamento 1, as espécies agrícolas foram plantadas em espaçamento de $1 \times 1,5 \mathrm{~m}$, com 2 a 3 sementes por cova, e no tratamento 2, o plantio das agrícolas obedeceu o mesmo espaçamento e as mudas foram plantadas em espaçamento de $3 \times 2 \mathrm{~m}$ (figura 7), alocadas ao acaso em cada linha. As sementes das espécies agrícolas foram adquiridas num formecedor comercial no Mercado municipal de Piracicaba.

00000000000000000000000000000000000000 00000000000000000000000000000000000000 00000000000000000000000000000000000000 00000000000000000000000000000000000000 00000000000000000000000000000000000000 00000000000000000000000000000000000000 00000000000000000000000000000000000000 00000000000000000000000000000000000000

TRATAMENTO 1

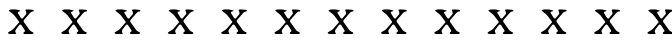
00000000000000000000000000000000000000 000000000000000000000000000000000000000

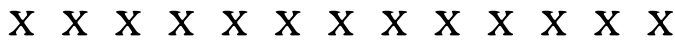
00000000000000000000000000000000000000 00000000000000000000000000000000000000

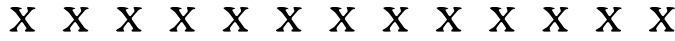
00000000000000000000000000000000000000

Figura 7. Croqui do plantio nos tratamentos 1, plantio agrícola, e 2, plantio agroflorestal.

O o representa as sementes agrícolas em espaçamento $1 \times 1,5 \mathrm{~m}$, e o X as mudas em $3 \times 2 \mathrm{~m}$. 
As parcelas foram sorteadas entre os tratamentos. $O$ plantio realizou-se logo após a poda dos cipós, em janeiro e fevereiro de 1997. Nestes meses, a precipitação na região foi de 337,5 mm e $141 \mathrm{~mm}$ respectivamente.

As parcelas instaladas estão dispostas na borda e no interior no fragmento e cada situação contém cinco repetições de cada tratamento (figura 8). Para localização dos trechos de capoeira baixa no fragmento e escolha das áreas experimentais foram feitas caminhadas ao longo de três transectos que cortam o fragmento e ao seu redor. As parcelas têm diferentes tamanhos, que variam de $154 \mathrm{~m}^{2}$ a $333 \mathrm{~m}^{2}$. Como os trechos de capoeira baixa ocorrem naturalmente no fragmento, optou-se por utilizar áreas em seus tamanhos originais para analisar a dinâmica em proporções reais. Escolher parcelas grandes impediria o uso de trechos de tamanho menor, e áreas pequenas poderiam desperdiçar áreas maiores de capoeira baixa ocorrentes no fragmento. $\mathrm{O}$ uso de parcelas de tamanho variável encontra precedentes na literatura florestal (Tabanez, 1995). 


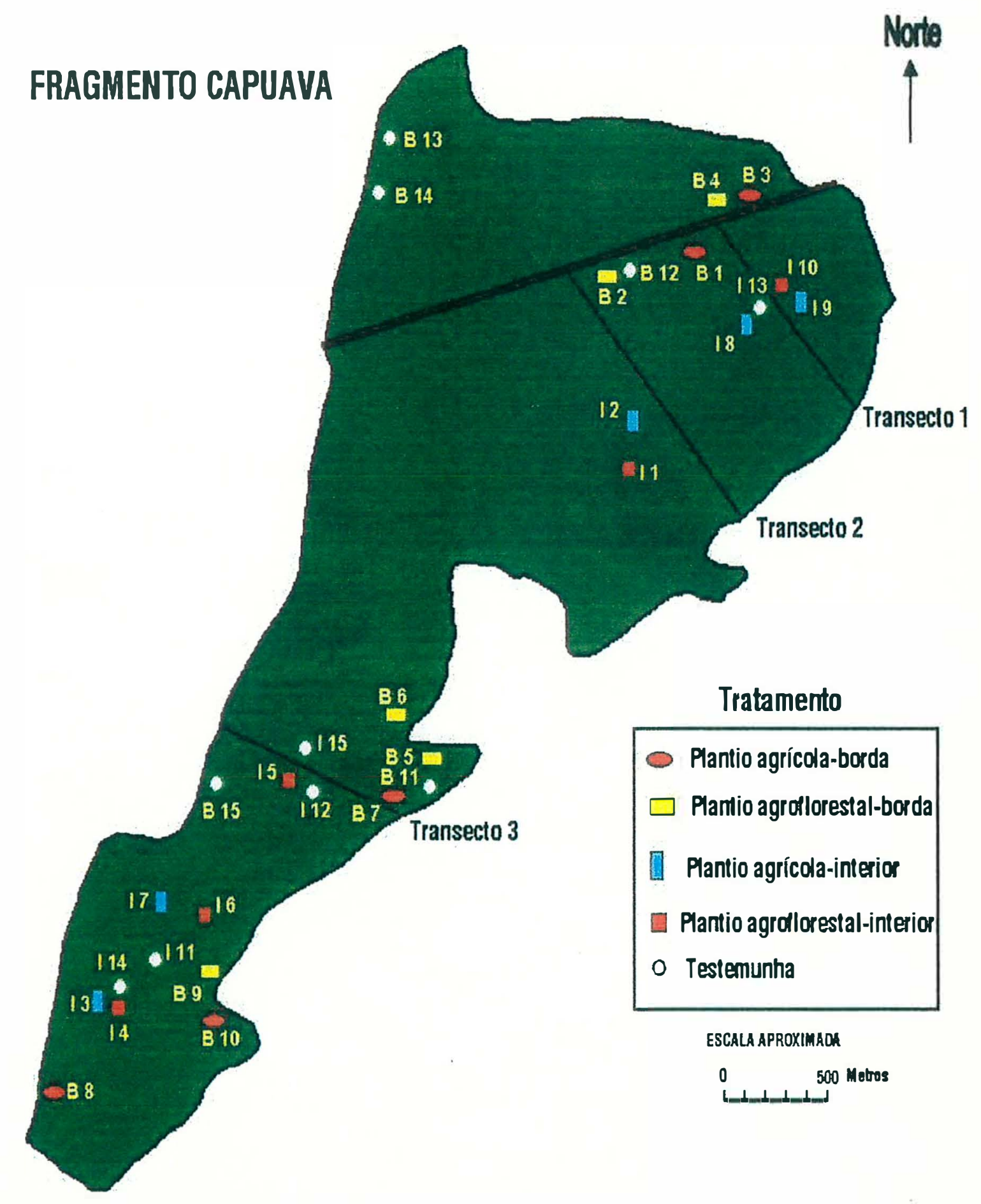

Figura 8. Croqui do fragmento Capuava com a localização das parcelas experimentais. 


\section{3 - ESCOLHA DAS ESPÉCIES ARBÓREAS E AGRÍCOLAS}

Para a escolha das espécies utilizadas no experimento foram considerados parâmetros ecológicos, sócio-culturais e econômicos. A escolha das espécies teve início com uma consulta à comunidade de trabalhadores da fazenda Capuava através da abordagem de espécies arbóreas nativas e agrícolas mais comuns na região. Este processo deu-se em entrevistas individuais utilizando um roteiro semi-estruturado e em reunião com a comunidade, onde foi montada uma matriz de critérios para espécies (capítulo 4). Moradores da comunidade já haviam plantado abóbora nas bordas do fragmento, inspirando a realização deste trabalho e indicando a importância da participação deles no processo de escolha de espécies e no desenvolvimento de estratégias para recuperação. Também foi feita uma pesquisa das espécies nativas da região, consulta ao levantamento da estrutura da comunidade arbórea do fragmento da Capuava (Tabanez, 1995) e consulta a pesquisadores com trabalhos desenvolvidos na região.

Os critérios para a escolha das espécies arbóreas consideraram: (i) a rapidez de crescimento e capacidade de sombreamento, que contribuem para a transformação rápida do ambiente, (ii) a resistência fisico-mecânica, para que as árvores suportem a dominância dos cipós, (iii) o valor econômico, para possibilitar o retomo econômico da recuperação a longo prazo com a perspectiva de manejo e (iv) a disponibilidade nos viveiros da região, pela viabilidade na aquisição das mudas. As espécies escolhidas foram : aroeira pimenteira (Schinus terebenthifolius Raddi), canafístula (Peltophorum dubium. (Spreng.)Taub.), guapuruvu (Schizolobium parahyba (Vell.) . Blake), ipê felpudo (Zeyheria tuberculosa (Vell.) Bur), jequitibá rosa (Cariniana legalis (Mart.). Kuntze), mutambo (Guazuma ulmifolia Lam.) e pau viola (Cytharexylum myrianthum Cham.) (tabela 2). 
Tabela 2. Espécies arbóreas escolhidas para o plantio e suas características.

\section{AROEIRA PIMENTEIRA}

(Schinus therebinthifolius Raddi):

Espécie de rápido crescimento, heliófita, perenifólia, alcança de 5 a 10 metros de altura, produz madeira resistente utilizada para mourões e esteios e é muito procurada pela avifauna, que a dispersa amplamente. Medicinalmente os ramos são usados em tratamento das vias respiratórias e urinárias e como estimulante dos órgãos digestivos.

\section{CANAFÍSTULA}

(Peltophorum dubium (Spreng.) Taub.)

Planta rústica, de rápido crescimento, decídua e heliófita. Omamental, com grande copa que proporciona boa sombra e com altura entre 15 e 25 metros. Sua madeira é moderadamente pesada e é usada na construção civil e marcenaria. Apresenta dispersão ampla e abundante. A casca contém tanino e serve para o curtume.

\section{GUAPURUVU}

(Schizolobium parahyba (Vell.) Blake)

É uma das plantas nativas de mais rápido crescimento. Com altura de 20 a 30 metros, é muito omamental quando em flor. É decídua, heliófita e exclusiva da Mata atlântica. A madeira é muito leve e indicada para miolo de painéis, forros e brinquedos.

\section{IPÊ FELPUDO}

(Zeyheria tuberculosa (Vell.) Bur.)

Planta semidecídua, heliófita, de rápido crescimento e muito omamental. Alcança entre 15 e 23 metros de altura, a madeira é leve e resistente, própria para construções intemas, papel e lenha.

\section{JEQUITIBÁ ROSA}

(Cariniana legalis (Mart.) Kuntze)

Planta majestosa, secundária, semidecídua, heliófita ou esciófita. Tolera ambientes abertos de formações secundárias e tem crescimento moderado. De alta longevidade, ocupa o dossel superior da floresta, com altura entre 30 e 50 metros. A madeira é própria para construção civil, móveis e brinquedos. Sua casca tem poder desinfetante e contém tanino.

\section{MUTAMBO}

(Guazuma ulmifolia Lam.)

Planta semidecídua, heliófita, de rápido crescimento. Seus frutos são muito apreciados por macacos e outros animais. Sua altura fica entre 8 e 16 metros, a madeira é leve, de boa durabilidade, usada em caixotaria e construções intemas.

\section{PAU VIOLA}

(Cytharexyllum myrianthum Cham.)

Planta heliófita, de rápido crescimento. Característica de terrenos úmidos, mas encontra-se também em terrenos secos. Sua altura alcança entre 8 e 20 metros. Seus frutos são muito apreciados pela avifauna que a dispersa amplamente. As flores são melíferas. A madeira é leve e macia, sendo usada para tabuado, brinquedos e instrumentos musicais, de onde inclusive veio seu nome, tanto científico como o vulgar.

Fonte : Lorenzi, 1992; Rodrigues et al., 1996.

As mudas para o plantio foram doadas pelo viveiro da SODEMAP (Sociedade de Defesa do Meio Ambiente de Piracicaba) através de um convênio com o ECOAR (Associação Ecoar 
Florestal) e pelo viveiro do IPEF/Departamento de Ciências Florestais, ESALQ, USP.

A escolha das espécies agrícolas deu-se a partir de variedades plantadas pela população local, considerando-se a possibilidade de substituição dos cipós presentes nas capoeiras baixas em seu papel ecológico. Avalia-se que a função que os cipós exercem nestas áreas é de cicatrização, com recobrimento rápido das áreas perturbadas pelas mudanças microclimáticas oriundas dos efeitos da fragmentação. A partir dos princípios de analogia e substituição (Hart, 1980) às espécies nativas, foram escolhidas culturas agrícolas que apresentam a mesma estratégia morfofisiológica dos cipós nativos, com hábito trepador/rasteiro e efetiva cobertura da área através do crescimento rápido e agressivo. As espécies escolhidas foram : abóbora menina (Cucurbita maxima Duch.), abóbora seca (Cucurbita moschata Duch. ex Lam.), abóbora moranga (Cucurbita pepo L.), pepino (Cucumis sativus L.), maxixe (Cucumis anguria L.), e chuchu (Sechium edule (Jacq.) Sw.). Não foram escolhidas espécies frutiferas perenes/semi-perenes por precaução quanto à atração para a entrada de pessoas no fragmento e por apresentarem produção a médio ou longo prazo, impossibilitando a avaliação em tempo hábil para esta pesquisa.

\section{4 - CRESCIMENTO DAS ÁRVORES PRÉ-EXISTENTES}

Foi feito um inventário das árvores com DAP igual ou superior a $5 \mathrm{~cm}$ existentes nas parcelas. As árvores foram marcadas e medidas na época da implantação do experimento (janeiro/fevereiro de 1997). A segunda medição foi feita um ano após, em fevereiro/março de 1998, com coleta de material botânico para identificação das espécies no Departamento de Botânica da ESALQ/USP. Foram calculados o recrutamento $\left(\mathrm{n}^{\circ}\right.$ de indivíduos recrutados por hectare para a classe de DAP $\geq 5 \mathrm{~cm}$ em 1 ano) e o incremento em área basal $\left(\mathrm{m}^{2} / \mathrm{ha}\right)$ e em densidade de árvores ( ${ }^{\circ}$ de indivíduos/ha). Estas três variáveis estão intrinsicamente relacionadas e podem indicar a dinâmica de mortalidade e recrutamento de árvores.

\section{5 - REGENERAÇÃO NATURAL}

As parcelas experimentais de capoeira baixa foram avaliadas quanto à densidade da regeneração natural. Em cada parcela foram alocadas quatro sub-parcelas, de $3 \times 3$ metros (9

$\mathrm{m}^{2}$ ), uma em cada ponto cardeal (figura 9). As sub-parcelas estão distantes aproximadamente 2 metros das bordas das parcelas. Foram inventariados todos os indivíduos de espécies arbóreas e arbustivas $\geq 50 \mathrm{~cm}$, medindo-se a altura e, para as plantas com mais de $1,5 \mathrm{~m}$ de altura, mediu-se 
também o DAP. A regeneração natural ocorrente nas sub-parcelas foi contada e medida em três fases : T1, um mês após o plantio, T2, seis meses após a primeira medida, e T3, um ano após a primeira. A primeira medida foi feita em março/abril de 1997, a segunda em setembro/outubro de 1997 e a terceira em março/abril de 1998.

As plântulas foram coletadas e a identificação feita no Departamento de Botânica da ESALQ/USP.

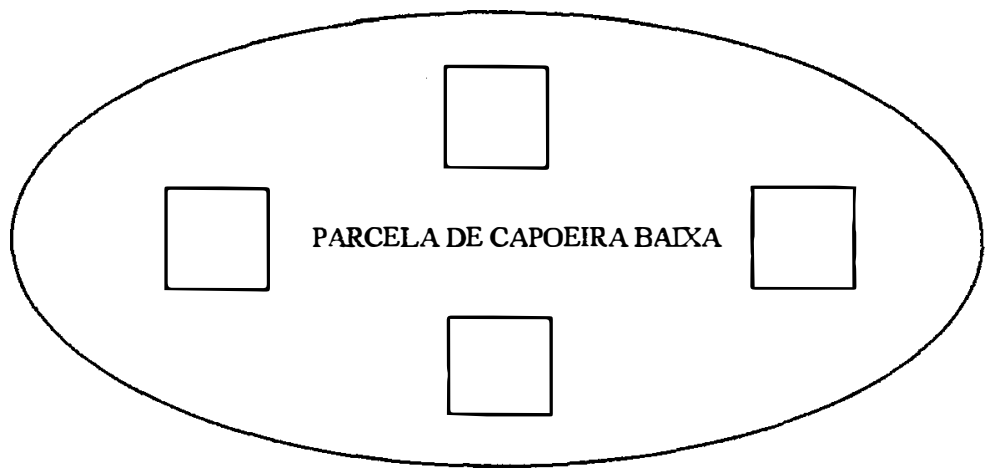

Figura 9. Parcela esquemática de capoeira baixa, onde se observam as sub-parcelas de $3 \times 3 \mathrm{~m}$. para acompanhamento da regeneração natural.

\section{6 - CRESCIMENTO DAS MUDAS PLANTADAS}

Foram medidas a altura e o diâmetro da copa das mudas plantadas. A altura foi medida do solo à gema apical da muda e o diâmetro da copa foi obtido pela média das duas medidas tiradas em cruz. Estes parâmetros podem indicar o ritmo de crescimento e a capacidade de sombreamento das espécies. A avaliação foi feita em dois períodos de 6 meses cada. $O$ primeiro período foi de T1 ( $1^{\mathrm{a}}$ medida, um mês após o plantio) a T2 ( $2^{\mathrm{a}}$ medida, sete meses após o plantio), e o segundo de T2 a T3 ( $3^{\mathrm{a}}$ medida, um ano após a primeira medida). A fím de verificar diferenças estatísticas do crescimento das mudas entre a borda e o interior do fragmento foi utilizado o teste T-Student para cada espécie nas situações de borda e interior. Foram plantadas sete espécies arbóreas em dez parcelas, cinco na borda e cinco no interior, totalizando 254 mudas.

\section{7 - PRODUÇÃO DAS ESPÉCIES AGRÍCOLAS}

A produção das espécies agrícolas foi colhida e pesada durante a época de colheita das culturas plantadas que foi entre abril e junho de 1997. A partir da produção do primeiro fruto 
foram feitas vistorias semanais em todas as parcelas e após a colheita a produção foi pesada em balança de precisão no Departamento de Horticultura da ESALQ/USP. Como muitos frutos apresentaram doenças, foram feitas análises para identificação das doenças na Clínica de Fitopatologia da ESALQ/USP. A partir dos dados de produção, foram feitas análises econômicas para a relação da receita obtida com o custo das operações.

\section{8 - ANÁLISE DOS DADOS}

Para verificar se há ou não diferenças estatísticas quanto aos efeitos da posição das parcelas, borda e interior, e aos tratamentos, agrícola, agroflorestal e testemunha, foi realizada a análise de variância (ANOVA) com a utilização do sistema SAS (Statistical Analysis System). 0 modelo adotado foi de parcelas sub-divididas ("split-plot") que testa simultaneamente os efeitos da posição e do tratamento. A parcela principal ("main plot") foi determinada pela posição, e os tratamentos, que estão alocados dentro das posições, representaram as sub-parcelas ("sub-plots"). $O$ recrutamento, incremento em área basal e densidade das árvores (DAP $\geq 5 \mathrm{~cm}$ ), e a densidade das plântulas recrutadas foram as váriáveis-respostas (dependentes); a posição e o tratamento, os fatores independentes.

\section{9 - O MANEJO}

Inicialmente foi feita uma diagnose visual quanto às principais características das parcelas experimentais de capoeira baixa. Apesar da homogeneidade estrutural aparente, que possibilitou a repetição para o delineamento experimental, observou-se diferenças em aspectos como o tipo de vizinhança, altura do dossel e dominância de espécies. Por isso, em cada área foi feita uma avaliação inicial para reconhecimento detalhado de cada parcela. $\mathbf{O}$ manejo iniciou com uma poda drástica nos cipós e arbustos decumbentes que foram picados e espalhados homogeneamente sobre o solo formando uma camada de serapilheira espessa. $\mathbf{O}$ plantio deu-se em seguida, com o planejamento feito em campo de acordo com a localização, a forma e o tamanho da parcela, sendo o espaçamento previamente determinado. Sete meses depois foi feita uma “jardinagem" nas parcelas com a poda dos cipós e arbustos que ameaçavam o desenvolvimento das mudas plantadas e/ou plântulas recrutadas. Um ano depois do manejo, na época de verão

\footnotetext{
${ }^{1}$ A jardinagem é um conceito, desenvolvido neste trabalho, utilizado para o manejo criterioso e seletivo em que algumas plantas são podadas em benefício de ouras, facilitando a sucessão.
} 
(fevereiro/março de 1998) em que chove muito e o crescimento das plantas é explosivo, foi feita outra jardinagem. Neste manejo foram utilizados o facão e a tesoura de poda, que são ferramentas ideais para este fim por possibilitarem a seletividade em áreas com intensa regeneração.

\subsection{0 - INDICADORES QUALITATIVOS}

Além das avaliações definidas quanto à densidade e diversidade da regeneração natural e das árvores pré-existentes, foram observados aspectos das áreas avaliadas abrangendo critérios semi-qualitativos quanto ao estado de desenvolvimento de cada sub-parcela $\left(9 \mathrm{~m}^{2}\right)$. A análise foi feita através de um roteiro previamente elaborado, sete meses após a instalação dos tratamentos. Os aspectos observados, avaliados comparativamente entre as sub-parcelas, referem-se a : (i) heterogeneidade dos consórcios da regeneração na sub-parcela, classificada em homogêneo ou heterogêneo, (ii) tipo de vegetação na vizinhança, classificado em "capoeira baixa", "bambuzal", "capoeira alta" e "mata madura", (iii) cobertura por cipós e arbustos decumbentes, classificada em alta, média e baixa, (iv) dominância disparada de determinada espécie, classificado em sim ou não (se sim, identificação da espécie) e (vi) elementos ecológicos presentes no momento da avaliação (presença de animais, seus vestígios ou outras formas de vida, como fungos). 0 levantamento destes dados pretendeu subsidiar o acompanhamento da pesquisa com indicadores qualitativos de avaliação.

\section{RESULTADOS E DISCUSSÃO}

\section{1 - INVENTÁRIO DAS ÁRVORES PRÉ-EXISTENTES}

No primeiro momento, a densidade de árvores (DAP $\geq 5 \mathrm{~cm}$ ) diferiu entre as áreas de capoeira baixa na borda e no interior, variando em média de 236,87 indivíduos/hectare nas áreas experimentais nas bordas a 384,80 nas áreas no interior e apresentou uma grande variação entre parcelas na mesma localização (tabelas 3 e 4). Esta variação confirma a heterogeneidade das capoeiras baixas, que são eco-mosaicos compostos por diversas eco-unidades que diferenciam as parcelas entre si e dentro de cada uma. A variação não está vinculada ao efeito de nenhum tratamento nem da posição das áreas, mas é intrinsicamente relacionada à dinâmica dos fragmentos e das capoeiras baixas. Esta heterogeneidade intema é observada também para clareiras (Martinez-Ramos, 1985). 
Tabela 3. Área basal média, mínima e máxima $\left(\mathrm{m}^{2} / \mathrm{ha}\right)$ das árvores (DAP $\geq 5 \mathrm{~cm}$ ) nas parcelas com tratamento 1, poda dos cipós e plantio agrícola, 2, poda dos cipós e plantio agroflorestal e 3, testemunha em T1 (momento de instalação do experimento) e T2 (um ano após T1).

\begin{tabular}{|l|r|r|r|r|r|r|r|r|}
\hline & \multicolumn{3}{|c|}{ Área basal em T1 (m²/ha) } & \multicolumn{3}{|c|}{ Área basal em T2 (m²/ha) } \\
\hline Tratamento & média & mínimo & máximo & $\begin{array}{l}\text { desvio } \\
\text { padrão }\end{array}$ & média & mínimo & máximo & $\begin{array}{l}\text { desvio } \\
\text { padrão }\end{array}$ \\
\hline Borda & & & & & & & & \\
\hline 1-Agricola & 2,16 & 0,41 & 3,69 & 2,32 & 3,04 & 1,25 & 5,22 & 2,80 \\
\hline 2-Agroflorestal & 5,68 & 1,18 & 15,50 & 10,12 & 5,99 & 0,33 & 17,48 & 12,12 \\
\hline 3-Testemunha & 2,60 & 0,71 & 5,18 & 3,16 & 2,29 & 0,46 & 3,83 & 2,37 \\
\hline Interior & & & & & & & & \\
\hline 1-Agrícola & 4,75 & 1,07 & 10,60 & 6,74 & 4,46 & 1,53 & 8,24 & 4,74 \\
\hline 2-Agroflorestal & 3,81 & 0,29 & 7,93 & 5,40 & 5,25 & 0 & 11,30 & $7,99 \mid$ \\
\hline 3-Testemunha & 4,31 & 1,58 & 8,44 & 4,84 & 4,35 & 1,56 & 9,23 & $5,41 \mid$ \\
\hline
\end{tabular}

Tabela 4. Densidade média, mínima e máxima $\left(\mathrm{n}^{\circ}\right.$. individuos $\left./ \mathrm{ha}\right)$ relativa às árvores $(\mathrm{DAP} \geq 5$ $\mathrm{cm}$ ) das parcelas com os tratamentos 1, poda dos cipós e plantio agrícola, 2, poda dos cipós e plantio agroflorestal e 3, testemunha em T1 (momento de instalação do experimento) e T2 (um ano após T1).

\begin{tabular}{|l|r|r|r|r|r|r|r|r|}
\hline & \multicolumn{3}{|c|}{ Densidade em T1 (ind./ha) } & \multicolumn{3}{c|}{ Densidade em T2 (ind./ha) } \\
\hline Tratamento & média & mínimo & máximo & $\begin{array}{l}\text { desvio } \\
\text { padrão }\end{array}$ & média & mínimo & máximo & $\begin{array}{l}\text { desvio } \\
\text { padrão }\end{array}$ \\
\hline Borda & & & $\mid$ & & & & & \\
\hline 1-Agrícola & 363,54 & 158,73 & 500 & 241,31 & 371,87 & 158,73 & 533,33 & 264,88 \\
\hline 2-Agroflorestal & 458,08 & 166,66 & 844,15 & 479,05 & 450,91 & 111,11 & 819,67 & 501,02 \\
\hline 3-Testemunha & 97,44 & 39,29 & 229,59 & 134,56 & 92,20 & 39,29 & 153,06 & 80,44 \\
\hline Interior & & & & & & & & \\
\hline 1-Agrícola & 434,23 & 238,09 & 641,02 & 284,91 & 444,54 & 317,46 & 606,06 & 204,07 \\
\hline 2-Agroflorestal & 471,53 & 129,31 & 1095,23 & 683,01 & 485,32 & 0 & 535,71 & 378,80 \\
\hline 3-Testemunha & 348,08 & 90,49 & 559,44 & 331,59 & 317,60 & 45,24 & 559,44 & 363,58 \\
\hline
\end{tabular}

Não houve diferença estatística significativa $(p>0,5)$ entre os tratamentos para recrutamento e incremento em área basal e em densidade, nem entre a situação de borda e interior, ou entre a interação da posição (borda e interior) com o tratamento (tabela 5). 
Tabela 5. Resultados da ANOVA dos efeitos da posição, borda e interior, do tratamento, 1,2 e 3 , e da interação dos fatores sobre o incremento em área basal, densidade e recrutamento de indivíduos (DAP $\geq 5 \mathrm{~cm}$ ) no intervalo de 1 ano.

\begin{tabular}{|c|c|c|c|}
\hline Efeito & GL & $F$ & $P$ \\
\hline \multicolumn{4}{|l|}{ Incremento em Área Basal } \\
\hline POSIÇÃO & 1 & 0,01 & 0,98 \\
\hline TRATAMENTO & 2 & 0,52 & 0,61 \\
\hline POSIÇÃO X TRATAMENTO & 2 & 2,85 & 0,13 \\
\hline \multicolumn{4}{|l|}{ Incremento em Densidade } \\
\hline POSIÇÃO & 1 & 0,03 & 0,87 \\
\hline TRATAMENTO & 2 & 0,42 & 0,67 \\
\hline POSIÇÃO X TRATAMENTO & 2 & 0,65 & 0,55 \\
\hline \multicolumn{4}{|l|}{ Recrutamento } \\
\hline POSIÇÃO & 1 & 0,41 & 0,54 \\
\hline TRATAMENTO & 2 & 2,02 & 0,21 \\
\hline POSIÇÃO X TRATAMENTO & 2 & 0,73 & 0,52 \\
\hline
\end{tabular}

Apesar de não haver diferenças significativas nas variáveis avaliadas, em um ano foi possível observar que: (i) nas áreas com tratamento 3 (testemunha) houve redução de área basal nas bordas e redução em densidade de árvores nas bordas e no interior, (ii) as áreas com tratamento 1 (plantio agrícola) apresentaram redução de área basal no interior e os maiores indices de recrutamento e (iii) as áreas com tratamento 2 (plantio agroflorestal), apresentaram maior incremento em área basal e densidade no interior do que nas bordas (figura 10). Observouse ocorrência de mortalidade de árvores nas capoeiras baixas (10 \%), razão pela qual houve variação negativa para área basal e densidade em algumas situações. Os dados ilustram os efeitos da degradação chegando ao interior a partir das bordas com redução do número de árvores adultas em um ano.

As árvores estão muitas vezes cobertas por cipós que, com seu peso, contribuem para a modificação da arquitetura e acarretam alto índice de mortalidade. A vulnerabilidade ao vento e a raios a partir do efeito de borda também é um fator importante para a mortalidade ou injúria de árvores localizadas nas bordas e em clareiras do fragmento. $\mathbf{O}$ efeito do manejo pôde ser sentido com maior recrutamento de árvores (DAP $\geq 5 \mathrm{~cm}$ ). $\mathrm{O}$ revolvimento do solo no plantio e o controle dos cipós e arbustos decumbentes permitiu que algumas plântulas fossem recrutadas para esta classe. Grande parte das árvores recrutadas são pioneiras, que pelo rápido crescimento puderam alcançar um DAP $\geq 5 \mathrm{~cm}$ em um ano. 

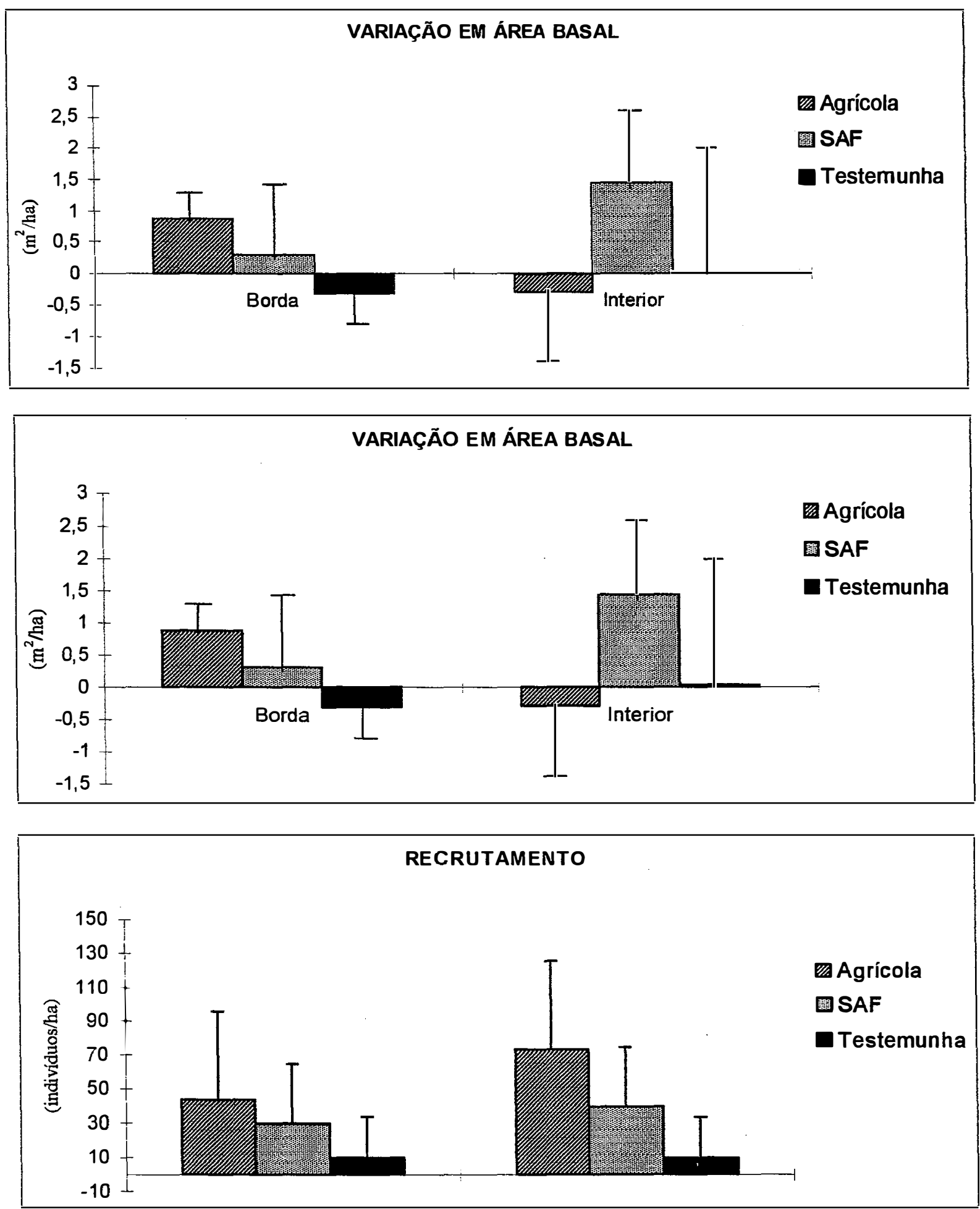

Figura 10. Variação em área basal, densidade e recrutamento de árvores (DAP $\geq 5 \mathrm{~cm}$ ) em um ano nos tratamentos 1 , poda de cipós e plantio agrícola, 2 , poda de cipós e plantio agroflorestal e 3 , testemunha. 
As poucas árvores encontradas nas capoeiras baixas formam nichos com condições especificas que desencadeiam a grande diversidade de eco-unidades e espécies na floresta. Apesar de poucas e muitas vezes injuriadas, as árvores nas capoeiras baixas exercem efeitos importantes na reestruturação e recomposição destas áreas, entre eles a manutenção de microclima favorável para a instalação de plântulas de diversos grupos ecológicos, o abrigo e alimento para a fauna e o formecimento de sementes, fundamentais para o repovoamento. $\mathrm{O}$ trabalho a partir das árvores presentes nas áreas pode otimizar as práticas de recuperação e beneficiar os processos sucessionais.

\section{2 - REGENERAÇÃO NATURAL}

Para a regeneração natural, o efeito do manejo teve uma grande influência na densidade de recrutamento de individuos arbóreos com altura $\geq 50 \mathrm{~cm}$. No entanto, a variação da intensidade de resposta das parcelas em cada tratamento foi elevada devido à grande heterogeneidade ambiental das capoeiras baixas. $\mathrm{O}$ microclima e o ambiente das clareiras são determinados por muitos fatores, tais como duração e intensidade de luz, que dependem do tamanho da clareira, forma, topografia, orientação, altura e tipo da vegetação vizinha e características da vegetação sobrevivente após a formação da clareira (Brokaw, 1985a). A heterogeneidade ambiental afeta grandemente a germinação de sementes e o estabelecimento de plântulas.

No primeiro momento ( $\mathrm{T} 1$, um mês após a instalação do experimento) não houve diferença significativa na densidade de plântulas entre os três tratamentos, mas nas outras medidas (T2, sete meses após $T 1$, e T3, um ano após $T 1)$, houve diferença significativa $(p=0,01$ em T2 e p = 0,0001 em T3). No entanto, não houve diferença entre as posições de borda e interior, nem entre a interação destes fatores (tabela 6).

Entre os tratamentos 1 e 2, plantio agrícola e agroflorestal, não houve diferença significativa, mas entre ambos e o tratamento testemunha houve diferença aos seis meses e um ano. $\mathrm{O}$ manejo foi determinante para o aumento da taxa de recrutamento de espécies arbóreas nas capoeiras baixas e a densidade média de plântulas recrutadas por parcela (tabela 7) demonstra padrões similares para as áreas de borda e de interior nos tratamentos instalados. 
Tabela 6. Resultados da ANOVA quanto aos efeitos da posição, borda e interior, e dos tratamentos 1, poda dos cipós e plantio agrícola, 2, poda dos cipós e plantio agroflorestal e 3 , testemunha, sobre a densidade de plântulas $(\mathrm{h} \geq 50 \mathrm{~cm})$ em três momentos : T1, 1 mês após a instalação do experimento, T2, 7 meses após o T1 e T3, 1 ano após T1.

\begin{tabular}{|c|c|c|c|}
\hline Efeito & GL & $F$ & $P$ \\
\hline \multicolumn{4}{|l|}{ T1 (1 mês) } \\
\hline POSIÇÃO & 1 & 0,79 & 0,38 \\
\hline TRATAMENTO & 2 & 0,56 & 0,57 \\
\hline POSIÇÃO X TRATAMENTO & 2 & 2,81 & 0,07 \\
\hline \multicolumn{4}{|l|}{ T2 (7 meses) } \\
\hline POSIÇÃO & 1 & 1,09 & 0,30 \\
\hline TRATAMENTO & 2 & 4,68 & 0,01 \\
\hline POSIÇÃO X TRATAMENTO & 2 & 3,0 & 0,05 \\
\hline \multicolumn{4}{|l|}{ T3 (1 ano) } \\
\hline POSIÇÃO & 1 & 1,40 & 0,24 \\
\hline TRATAMENTO & 2 & 19,29 & 0,0001 \\
\hline POSIÇÃO X TRATAMENTO & 2 & 2,15 & 0,12 \\
\hline
\end{tabular}

O efeito da poda dos cipós e arbustos decumbentes e o revolvimento do solo para o plantio, procedimento adotado para os dois sistemas de manejo, contribuiu para promover maior densidade de recrutamento. Observou-se que o plantio das espécies agrícolas e arbóreas não . exerceu nenhum efeito diferenciador entre as parcelas. A poda dos cipós abriu espaço físico e permitiu maior incidência de luz no solo, favorecendo o recrutamento de certas espécies. A frutificação e a chuva de sementes de algumas árvores coincidiu com a "abertura" de certas áreas experimentais, contribuindo também para o aumento da densidade de recrutamento. $\mathbf{O}$ revolvimento do solo facilitou a germinação de sementes de algumas espécies presentes no banco do solo, como Solanum granuloso-leprosum (fumo bravo) e Trema micrantha (pau pólvora), ao traze-las para a camada superficial.

O controle de espécies em desequilíbrio populacional nas capoeiras baixas pode trazer beneficios ambientais ao acelerar a sucessão secundária. Nas capoeiras baixas do fragmento em estudo, lianas e arbustos decumbentes aparecem em grande densidade como conseqüência da situação de distúrbio do fragmento. Este desequilíbrio representa uma causa secundária de degradação ao inibir a regeneração natural de espécies arbóreas (Tabanez, 1995). 0 crescimento inicial das lianas ocorre principalmente em clareiras e interfere muito na regeneração arbórea (Brokaw, 1985a). Comparativamente, o baixo investimento em auto-suporte permite um crescimento vigoroso que aumenta a mortalidade e retarda o crescimento das árvores hospedeiras 
(Putz, 1983). O controle de cipós e arbustos decumbentes busca aumentar a capacidade de sobrevivência das plântulas e árvores nas capoeiras baixas. A interação das espécies recrutadas com os cipós definirá a probabilidade de sobrevivência e crescimento até a maturidade das plântulas. Em trabalho realizado neste mesmo fragmento com objetivo de recuperação de capoeiras baixas foram testados tratamentos com plantio de espécies arbóreas e controle de cipós, obtendo-se em um ano respectivamente 6.657 plântulas/ha e 1.638 plântulas/ha (Tabanez, 1995). Como estes números equivalem à plântulas com altura $\geq 5 \mathrm{~cm}$, não são diretamente comparáveis aos obtidos neste trabalho, mas podem ser referência para a discussão.

Tabela 7. Densidade média, mínima e máxima de plântulas/hectare nos tratamentos 1 , poda de cipós e plantio agrícola, 2, poda de cipós e plantio agroflorestal e 3, testemunha, em três momentos: um mês, sete meses e um ano após a instalação do experimento.

\begin{tabular}{|c|c|c|c|c|c|c|c|c|c|}
\hline \multicolumn{10}{|c|}{ INTERIOR DO FRAGMENTO } \\
\hline & \multicolumn{3}{|c|}{$\begin{array}{c}\text { TRATAMENTO } \\
\text { AGRÍCOLA } \\
\end{array}$} & \multicolumn{3}{|c|}{$\begin{array}{c}\text { TRATAMENTO } \\
\text { AGROFLORESTAL }\end{array}$} & \multicolumn{3}{|c|}{$\begin{array}{l}\text { TRATAMENTO } \\
\text { TESTEMUNHA }\end{array}$} \\
\hline & Média & mínima & máxima & Média & mínima & máxima & média & mínima & máxima \\
\hline 1 mês & 500 & 350 & 600 & 320 & 0 & 700 & 680 & 250 & 1700 \\
\hline 7 meses & 1320 & 950 & 2200 & 930 & 350 & 1300 & 780 & 200 & 2200 \\
\hline 1 ano & 2380 & 1650 & 3100 & 1870 & 500 & 3050 & 760 & 150 & 1850 \\
\hline \multicolumn{10}{|c|}{ BORDA DO FRAGMENTO } \\
\hline & \multicolumn{3}{|c|}{$\begin{array}{c}\text { TRATAMENTO } \\
\text { AGRÍCOLA }\end{array}$} & \multicolumn{3}{|c|}{$\begin{array}{c}\text { TRATAMENTO } \\
\text { AGROFLORESTAL }\end{array}$} & \multicolumn{3}{|c|}{$\begin{array}{l}\text { TRATAMENTO } \\
\text { TESTEMUNHA }\end{array}$} \\
\hline & Média & mínima & máxima & média & mínima & máxima & média & mínima & máxima \\
\hline 1 mês & 400 & 200 & 850 & 600 & 100 & 1800 & 387 & 100 & 800 \\
\hline 7 meses & 950 & 350 & 2150 & 1250 & 300 & 3650 & 400 & 100 & 800 \\
\hline 1 ano & 2087 & 1350 & 2700 & 2312 & 1500 & 4300 & 400 & 100 & 750 \\
\hline
\end{tabular}

A regeneração natural tem efeitos importantes na arquitetura, composição e dinâmica de populações arbóreas, o que sugere que para a interpretação da dinâmica florestal seja indicado o estudo da regeneração em clareiras de diferentes tamanhos (Brokaw, 1985b). A clareira é considerada o motor responsável pela dinâmica das florestas, permitindo que sejam vistas como mosaicos de clareiras de diferentes tamanhos e idades, em diferentes estágios de sucessão, estando a regeneração natural das espécies arbóreas intimamente ligada à sucessão e à dinâmica de clareiras (Kageyama \& Gandara, 1993). A capoeira baixa é geralmente formada por queda de 
árvores como uma clareira normal, no entanto apresenta baixa presença de regeneração natural de espécies arbóreas. Para recuperação de capoeiras baixas deve-se otimizar os mecanismos naturais para reabilitação das funções e aceleração e facilitação da sucessão secundária.

O recrutamento de plântulas de espécies arbóreas através da regeneração natural pode ser obtido com práticas simples e econômicas e, em algumas situações, pode ultrapassar a densidade obtida em plantios convencionais de árvores (tabela 8). Os sistemas agroflorestais na recuperação de fragmentos podem prescindir do plantio de árvores ao integrar e otimizar as árvores existentes e as recrutadas onde existam meios de regeneração biótica. Nas áreas internas do fragmento, onde operacionalmente o plantio de mudas e o manejo agrícola é mais caro e difícil e, onde há maior quantidade e diversidade de fontes de propágulos, somente o controle das espécies em desequilíbrio populacional já pode trazer resultados satisfatórios para a aceleração da sucessão. Nas áreas de borda, por serem mais sujeitas à perturbações diretas, o manejo deve ser mais intensivo para uma minimização do efeito de borda. Uma zona tampão entre o fragmento e as atividades agrícolas do entorno podem reduzir os efeitos negativos desta abrupta interface. A manutenção do manejo em ambas as situações deve ser monitorada de acordo com as características da área (tamanho, posição e vizinhança), a dinâmica das eco-unidades e as estações do ano.

Tabela 8. Densidade da regeneração natural (plântulas/hectare) e de mudas em plantio convencional com espaçamento $3 \times 2 \mathrm{~m}$ (plantas/hectare). A densidade da regeneração natural tem base na obtida em um ano nas situações de borda e interior com os tratamentos 1, poda dos cipós e plantio agrícola, 2, poda dos cipós e plantio agroflorestal e 3, testemunha.

\begin{tabular}{|c|c|c|}
\hline CATEGORIA DE MANEJO & $\begin{array}{c}\text { DENSIDADE DA } \\
\text { REGENERAÇÃO NATURAL } \\
\text { (plântulas/ha) }\end{array}$ & $\begin{array}{c}\text { DENSIDADE DE } \\
\text { MUDAS } \\
\text { (plantas/ha) }\end{array}$ \\
\hline BORDA & & \\
\hline TRAT. AGRÍCOLA & 2.087 & 1.666 \\
\hline TRAT. AGROFLORESTAL & 2.312 & \\
\hline TRAT. TESTEMUNHA & 400 & \\
\hline INTERIOR & & 1.666 \\
\hline TRAT. AGRÍCOLA & 2.380 & \\
\hline TRAT. AGROFLORESTAL & 1.870 & \\
\hline TRAT. TESTEMUNHA & 760 & \\
\hline
\end{tabular}




\section{3 - CRESCIMENTO DAS ESPÉCIES ARBÓREAS PLANTADAS}

A escolha das espécies arbóreas teve início com um levantamento junto à comunidade de moradores da fazenda Capuava. Foi montada uma matriz de critérios para a caracterização de espécies que funcionou como um exercício e dinâmica lúdica para suscitar a discussão acerca das altemativas para a recuperação de fragmentos florestais. Após consulta à listas de espécies arbóreas nativas da região e a pesquisadores da área, foram eleitas as espécies para compor o experimento. Foram priorizadas espécies do grupo ecológico "secundárias iniciais" que apresentam características desejadas na recuperação, tais como rápido crescimento, dispersão de sementes por vento, pássaros e morcegos e sementes pequenas e viáveis por longo tempo (Budowski, 1965). Prevendo o estímulo à germinação do banco de sementes de espécies pioneiras locais pelo revolvimento do solo nos tratamentos instalados, considerou-se desnecessário o plantio de espécies arbóreas deste grupo ecológico, fundamentais no desenvolvimento da sucessão. Por outro lado, as espécies de grupos ecológicos sucessionais mais tardios apresentam crescimento relativo mais lento, não adequando-se à situação das capoeiras baixas e aos objetivos emergenciais da recuperação.

As espécies apresentaram comportamentos distintos de acordo com suas características específicas e a interação com os micro-ambientes em que estão plantadas. Em um ano as mudas apresentaram alta taxa de sobrevivência (85\%) (tabela 9) e crescimento diferenciado entre as espécies (figura 11).

Tabela 9. Mortalidade das espécies arbóreas plantadas por parcela e por espécie.

\begin{tabular}{|l|l|l|l|l|l|}
\hline & \multicolumn{2}{|c|}{ Parcelas na borda } & \multicolumn{2}{c|}{ Parcelas no interior } & Borda e interior \\
\hline Espécies & $\begin{array}{l}\text { Número de } \\
\text { mudas } \\
\text { plantadas }\end{array}$ & $\begin{array}{l}\text { Número de } \\
\text { mudas mortas }\end{array}$ & $\begin{array}{l}\text { Número de } \\
\text { mudas } \\
\text { plantadas }\end{array}$ & $\begin{array}{l}\text { Número de } \\
\text { mudas mortas }\end{array}$ & $\begin{array}{l}\text { Porcentagem de } \\
\text { mortalidade total } \\
\text { por espécie (\%) }\end{array}$ \\
\hline aroeira & 18 & 4 & 15 & 1 & 15 \\
\hline canafistula & 15 & 1 & 116 & 1 & 6,5 \\
\hline guapuruvu & 18 & 0 & 16 & 1 & 3 \\
\hline ipê felpudo & 20 & 1 & 16 & 2 & 8 \\
\hline jequitibá & 18 & 7 & 17 & 4 & 31,5 \\
\hline mutambo & 16 & 8 & 17 & 4 & 36 \\
\hline pau viola & 20 & 1 & 19 & 1 & 5 \\
\hline
\end{tabular}



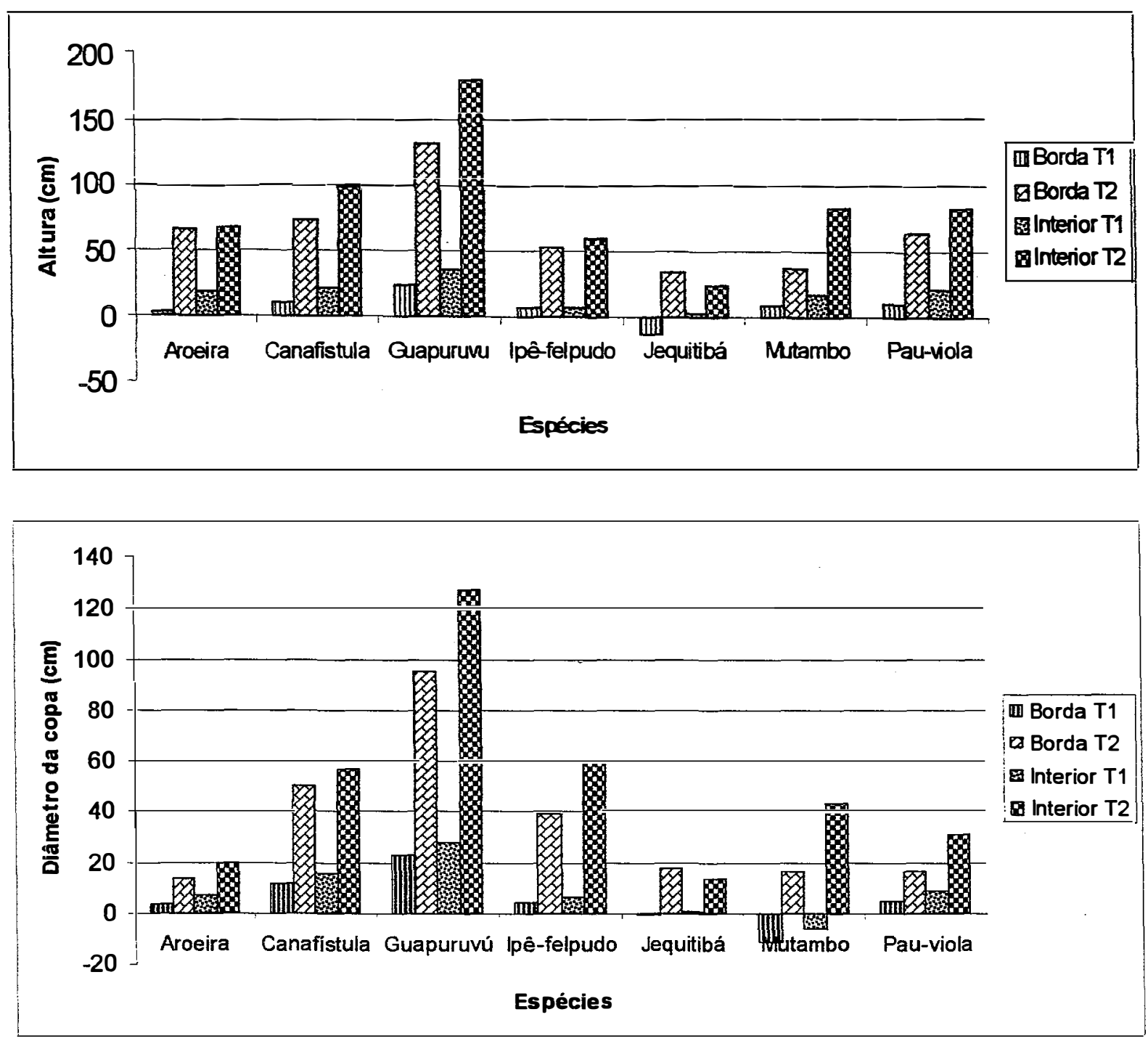

Figura 11. Crescimento das mudas plantadas em diâmetro da copa e altura. As medidas foram obtidas em dois intervalos de 6 meses : T1, do plantio a seis meses após o plantio, e T2, de seis meses a um ano após o plantio.

O incremento, tanto em altura como em diâmetro da copa, foi maior no segundo período (de seis meses a um ano), provavelmente pelo fato de ser a época mais quente e chuvosa na região. As espécies diferenciaram-se muito no crescimento em ambas as variáveis. $O$ guapuruvu 
(Schizolobium parahyba) é o que desenvolveu-se melhor, tanto na borda como no interior, alcançando até 5,5 $\mathrm{m}$ de altura em um ano. $\mathrm{O}$ mutambo (Guazuma ulmifolia) apresentou diâmetro de copa pequeno e alta mortalidade, sendo uma espécie que não teve boa performance nas áreas experimentais. $\mathrm{O}$ jequitibá rosa (Cariniana legalis) apresentou crescimento relativamente lento e alta taxa de mortalidade, apresentando, na época da segunda medição, apenas rebrotas baixas na maior parte das plantas. Em áreas de interior, onde há maior sombreamento e umidade, o jequitibá apresentou melhor performance, alcançando até $1,5 \mathrm{~m}$ após um ano de plantio. De forma geral, as espécies desenvolveram-se melhor nas parcelas no interior do que nas bordas do fragmento.

O plantio das mudas enriqueceu o fragmento com aumento da população de espécies já presentes e a reintrodução de espécies nativas da região que já não mais se encontram neste fragmento. Outras espécies devem ser testadas e utilizadas em plantios de enriquecimento em fragmentos florestais. $\mathbf{O}$ espaçamento foi adequado, mas observa-se que o plantio em consórcios, de forma mais adensada de acordo com a altura e o ciclo de vida das espécies, pode ser interessante para formar mais rapidamente uma estrutura similar à floresta conservada, estratificada e diversificada. Os núcleos podem mais rapidamente criar condições para que espécies mais exigentes em sombra, umidade e nutrientes se estabeleçam via regeneração natural. Observou-se que as plântulas recrutadas freqüentemente formam agrupamentos criando consórcios naturais, o que confirma esta estratégia natural de ocupação.

\section{4 - PRODUÇ̃̃O DAS ESPÉCIES AGRÍCOLAS}

A produção das espécies agrícolas (tabela 10) foi colhida e pesada nos meses de abril, maio e junho de 1997. As espécies colhidas foram as variedades de abóbora (moranga, menina e seca) e o pepino. $O$ maxixe não apresentou germinação das sementes, acreditando-se que não estavam viáveis. $\mathbf{O}$ chuchu só começou a produzir frutos um ano após o plantio e muitas plantas desta espécie foram perdidas em meio aos cipós nativos por terem sido plantadas nas bordas das parcelas. Não foi possível medir a produção desta cultura.

A produção agrícola obtida foi baixa de forma geral, havendo parcelas sem nenhuma produção. Seis parcelas apresentaram produção, quatro no interior do fragmento e duas na borda, e as demais produziram frutos com doenças ou não futtificaram. As parcelas que obtiveram maiores níveis de produção, localizadas no interior do fragmento, estão voltadas para a face norte, que recebe maior insolação diária. 
Tabela 10. Produção agrícola $(\mathrm{kg})$ média, mínima e máxima das parcelas (de 154 a $333 \mathrm{~m}^{2}$ ) com os tratamentos 1 , plantio agrícola e 2, plantio agroflorestal, na borda e no interior do fragmento.

\begin{tabular}{|l|l|l|l|}
\hline Posição das parcelas & Produção média & Produção mínima & Produção máxima \\
\hline Borda & 7,13 & 6,4 & 7,86 \\
\hline Interior & 11,34 & 0,89 & 17,63 \\
\hline
\end{tabular}

Houve ocorrência de doenças nos frutos e nas folhas de abóboras e de pepino. Nas folhas das abóboras apresentando manchas brancas, foram encontrados fungos que foram identificados na clínica de fitopatologia da ESALQ/USP como "oídio" (Erysiphe cichoracearum) e "míldio" (Pseudoperonospora cubensis). Nos frutos de abóbora e pepino a doença se manifestou por deformação dos frutos e podridão iniciada na ponta do fruto. A doença, identificada como "podridão gomosa", é causada por agentes patogênicos que penetram por ferimentos nos frutos (Galli et al., 1968). Estes ferimentos foram, provavelmente, provocados por animais do fragmento. Avalia-se que o microclima da floresta mantém alta a umidade, propiciando a germinação de fungos. As cucurbitáceas são vulneráveis a fungos que dependem de condições de umidade e temperatura, além de variações climáticas, para se manifestarem (Prof. Raul Lucena, UFRRJ, comunicação pessoal). As culturas plantadas são em maior parte rasteiras, desenvolvendo-se próximo ao solo, onde nas clareiras ocorre a máxima variação microclimática em plano vertical (Martinez-Ramos, 1985). As parcelas voltadas para a face Sul ou com a vegetação de sua vizinhança alta, têm a intensidade diária de insolação reduzida e, as culturas agrícolas escolhidas requerem luz por um período diário longo. A época do plantio (janeiro de 1997) foi tardia, sendo a época do início das chuvas na região (entre outubro e dezembro) a mais apropriada para o plantio destas culturas. A produtividade obtida foi subestimada em relação à potencial tanto pela época de plantio, como pela condição imprópria para estas culturas encontrada em várias parcelas experimentais.

As espécies agrícolas exerceram papel de bio-indicadores, revelando em pouco tempo a heterogeneidade entre as parcelas. A grande variação no crescimento e produção das variedades agrícolas indicou que as capoeiras baixas, apresentando estrutura e composição de espécies dominantes similares, diferem muito entre si nos padrões de luz e umidade. Assim, recomenda-se que os sistemas de manejo e as espécies plantadas sejam diversificadas, diferenciando-se a partir das características das eco-unidades. 
Uma grande lacuna ainda existe para a consecução de agroecossistemas diversificados, fazendo-se necessário um maior conhecimento das características ecológicas das espécies agrícolas para encaixá-las nos sítios mais apropriados. São necessários estudos que avaliem o comportamento das espécies agrícolas em ambientes heterogêneos e em consórcios com outras espécies para um maior entendimento de suas características ecofisiológicas. As espécies agrícolas vêm sendo cultivadas industrialmente em condições artificiais e sofrem melhoramentos genéticos voltados à maximização da produção em ambientes homogêneos "ilusórios". Os sistemas agroflorestais partem de outro paradigma : as espécies agrícolas fazem parte do agroecossistema e exercem papel ecológico na comunidade.

É importante o resgate de variedades tradicionais locais, que normalmente são mais nústicas e adaptadas às condições locais. Para a adequação das espécies às áreas de plantio, ressalta-se a importância da observação quanto à : intensidade de luz diária, orientação cardeal, tamanho da área, tipo de vizinhança e espécies presentes. Deve-se, no entanto, considerar que as áreas estão em constante transformação e o manejo deve acompanhar este fluxo dinâmico. Diversas variedades agrícolas e espécies arbóreas devem ser testadas e podem contribuir para um retomo econômico que compense os custos de projetos de recuperação. A diversidade de espécies é primordial para a composição de sistemas agroflorestais em áreas heterogêneas, principalmente quando se busca a recuperação de uma floresta.

\section{5 - ANÁLISE ECONÔMICA}

A compensação dos custos para a recuperação das áreas experimentais de capoeira baixa foi obtida em parte, com uma pequena receita oriunda da produção agrícola. 0 balanço econômico do manejo indica os gastos realizados e a receita obtida : os gastos corresponderam ao pagamento de trabalhadores para o corte de cipós e plantio, aquisição das sementes de espécies agrícolas e mudas de espécies arbóreas (tabela 11). A área experimental, com os tratamentos 1 , poda de cipós e plantio agrícola e 2, poda de cipós e plantio agroflorestal, equivale a $4270 \mathrm{~m}^{2}$. Os custos foram calculados em relação à área total do experimento e os valores foram extrapolados para um hectare, possibilitando análises comparativas. Das seis parcelas que apresentaram produção agrícola, três tiveram o tratamento 1 e as outras três o tratamento 2 . 0 cálculo do custo destas parcelas fornece parâmetros para compará-lo à receita obtida, que representa o capital gerado pela venda dos produtos agrícolas. 
Tabela 11. Custos das operações e dos tratamentos 1 , poda de cipós e plantio agrícola e 2, poda de cipós e plantio agroflorestal, em reais (R\$) e em dólar (US\$).

\begin{tabular}{|c|c|c|c|c|c|}
\hline ATIVIDADE & Quantidade & $\begin{array}{c}\text { Custo } \\
\text { unitário } \\
\text { RS / US\$* }\end{array}$ & $\begin{array}{c}\text { Custo da área } \\
\text { experimental } \\
\left(4270 \mathrm{~m}^{2}\right) \\
\text { RS / US\$* }\end{array}$ & $\begin{array}{c}\text { Custo em um } \\
\text { hectare } \\
\text { RS / US\$* }\end{array}$ & $\begin{array}{c}\text { Custo das seis } \\
\text { parcelas } \\
\text { produtivas } \\
\text { RS / US\$* }\end{array}$ \\
\hline $\begin{array}{c}\text { Mão-de-obra } \\
\text { (corte de cipós } \\
\text { e plantio) (1) }\end{array}$ & $\begin{array}{l}150 \mathrm{~m}^{2} / \\
\text { homem/ dia }\end{array}$ & $12,00 / 10,00$ & $336,00 / 280,00$ & $786,88 / 655,73$ & $100,80 / 84,00$ \\
\hline $\begin{array}{c}\text { Sementes de } \\
\text { abóbora seca e } \\
\text { menina (2) }\end{array}$ & 50 gramas & $10,00 / 8,33$ & $20,00 / 16,66$ & $46,83 / 39,00$ & $3,00 / 2,50$ \\
\hline $\begin{array}{l}\text { Sementes de } \\
\text { moranga e } \\
\text { pepino (2) } \\
\end{array}$ & 100 gramas & $6,00 / 5,00$ & $12,00 / 10,00$ & $28,10 / 23,40$ & $3,60 / 3,00$ \\
\hline Mudas (3) & 254 unidades & $0,75 / 0,62$ & $190,50 / 158,75$ & $446,13 / 371,77$ & $57,15 / 47,62$ \\
\hline \multicolumn{3}{|c|}{$\begin{array}{l}\text { Custo de toda a área experimental - } \\
\text { tratamentos } 1 \text { e } 2\end{array}$} & $558,50 / 465,41$ & $1307,95 / 1089,95$ & $164,55 / 137,12$ \\
\hline \multicolumn{3}{|c|}{$\begin{array}{l}\text { Custo do tratamento } 1 \text { - agrícola } \\
\text { (10 parcelas) }\end{array}$} & $184,00 / 153,33$ & 430,91/359,09 & $53,70 / 44,75$ \\
\hline \multicolumn{3}{|c|}{$\begin{array}{l}\text { Custo do tratamento } 2 \text { - agroflorestal } \\
\text { (10 parcelas) }\end{array}$} & $374,50 / 312,00$ & $877,04 / 730,86$ & 110,85/92,37 \\
\hline
\end{tabular}

* valores convertidos para dólar com a cotação do mês de dezembro de 1998 (US\$1 = R \$1,20)

Memória de cálculo :

(1) Mão-de-obra : $\mathrm{R} \$ 12,00 /$ dia $\times 28$ dias $=\mathrm{R} \$ 336,00=\mathrm{US} \$ 280,00$

(2) Sementes :

$$
\begin{aligned}
& \text { abóbora seca }-\mathrm{R} \$ 10,00 / 50 \text { gr. } \times 1=\mathrm{R} \$ 10,00=\mathrm{US} \$ 8,33 \\
& \text { abóbora menina }-\mathrm{R} \$ 10,00 / 50 \mathrm{gr} \times 1=\mathrm{R} \$ 10,00=\mathrm{US} \$ 8,33 \\
& \text { abóbora moranga }-\mathrm{R} \$ 6,00 / 100 \mathrm{gr} \times 1=\mathrm{R} \$ 6,00=\mathrm{US} \$ 5,00 \\
& \text { pepino - } \mathrm{R} \$ 6,00 / 100 \mathrm{gr} \times 1=\mathrm{R} \$ 6,00=\mathrm{US} \$ 5,00
\end{aligned}
$$

(3) Mudas : 254 unidades $x$ R $\$ 0,75=R \$ 190,50=U S \$ 158,75$

O custo para implantação dos tratamentos está relacionado principalmente à mão-de-obra para o corte de cipós e plantio. A altemativa de produção agrícola aliada à recuperação florestal pode ser atrativa para o pagamento de trabalhadores rurais, principalmente na época de entressafra da cana-de-açúcar, em que muitos trabalhadores ficam desempregados na região. Com sistemas utilizando culturas agrícolas prevê-se um manejo mais intensivo pela colheita da 
produção que pode trazer um retomo econômico, compensando o custo das operações. Desta forma, ao manejar o fragmento podando cipós, pode-se também "colher os frutos" do manejo. 0 custo do tratamento com plantio de mudas ainda é relativamente alto, próximo ao custo de replantio de florestas nativas, nas áreas da CESP por exemplo, que é por volta de US $\$ 1.500,00$ (Prof. Paulo Kageyama, comunicação pessoal). Em experiência similar, o custo para o manejo de capoeira baixa com plantio de espécies arbóreas foi de U\$1.786,11/ha e, para o manejo com corte de cipós foi U\$ 387,29/ha (Tabanez, 1995). Como os resultados obtidos neste trabalho demonstram uma alta capacidade da regeneração natural ocupar as capoeiras baixas degradadas após as práticas de manejo com a poda de cipós e revolvimento do solo, conclui-se que o plantio de mudas, que é caro e incerto, é desnecessário para a recuperação destas áreas.

A receita líquida (tabela 12 ) obtida representa $10 \%$ dos custos totais dos tratamentos e $30 \%$ do custo das seis parcelas produtivas. A receita foi baixa, mas sendo uma experiência pioneira indica perspectivas na busca pela redução dos custos e viabilidade para a recuperação de fragmentos.

Tabela 12. Total da produção agrícola e receita (em reais e em dólar) nas áreas experimentais com os tratamentos 1 , poda de cipós e plantio agrícola e 2 , poda de cipós e plantio agroflorestal.

\begin{tabular}{|l|l|l|l|l|l|}
\hline PRODUTO & $\begin{array}{l}\text { Preço de } \\
\text { mercado } \\
\text { (R\$/ kg) }\end{array}$ & $\begin{array}{l}\text { Total de } \\
\text { produção } \\
(\mathbf{k g})\end{array}$ & $\begin{array}{l}\text { Receita total da } \\
\text { produção } \\
\mathbf{R \$} / \text { US\$* }\end{array}$ & $\begin{array}{l}\text { Receita para } \\
\text { um hectare } \\
\text { R\$/ US\$* }\end{array}$ & $\begin{array}{l}\text { Receita da } \\
\text { parcela com } \\
\text { maior produção } \\
\text { R\$/ US\$* }\end{array}$ \\
\hline $\begin{array}{l}\text { Abóbora } \\
\text { moranga }\end{array}$ & 0,79 & 22,900 & $18,09 / 15,07$ & $42,36 / 35,30$ & $6,16 / 5,13$ \\
\hline $\begin{array}{l}\text { Abóbora } \\
\text { seca }\end{array}$ & 0,89 & 27,930 & $24,85 / 20,70$ & $58,19 / 48,49$ & $7,56 / 6,30$ \\
\hline $\begin{array}{l}\text { Abóbora } \\
\text { menina }\end{array}$ & 0,89 & 6,680 & $5,94 / 4,95$ & $13,91 / 11,59$ & $2,84 / 2,36$ \\
\hline Pepino & 0,80 & 2,260 & $1,80 / 1,50$ & $4,21 / 3,50$ & $0,35 / 0,29$ \\
\hline Total & & $\mathbf{5 9 , 6 3}$ & $\mathbf{5 0 , 6 8 / 4 2 , 2 3}$ & $\mathbf{1 1 8 , 6 8 / 9 8 , 9 0}$ & $\mathbf{1 6 , 9 1 / 1 4 , 0 9}$ \\
\hline
\end{tabular}

* valores convertidos para dólar com a cotação do mês de dezembro de 1998 (US\$1 = R \$1,20).

** $O$ preço de mercado foi obtido através da média de preços de três mercados em Piracicaba, SP, em maio de 1997.

Durante a colheita foram entrevistados alguns moradores da comunidade de trabalhadores da fazenda a respeito da agregação de valores aos produtos primários, que já vem sendo feita por diversas cooperativas e associações de pequeno produtores (Brasília Rural, 1996). As mulheres 
da comunidade fazem tradicionalmente doces e geléias e as abóboras colhidas no experimento foram aproveitadas por elas para a fabricação de doce de abóbora.

\section{6 - O MANEJO}

O manejo adotado nos tratamentos 1 e 2 iniciou com uma poda drástica, em que as lianas e arbustos decumbentes dominantes nas capoeiras baixas foram cortados na base. $\mathbf{O}$ termo "poda" neste caso expressa a prática de manejo em que a planta não é retirada do sistema, mas conduzida e controlada em seu crescimento. Em recuperação de fragmentos florestais foi utilizado o conceito de corte de cipós ou controle de cipós (Tabanez, 1995). No entanto, após o “corte dos cipós", observa-se que a maior parte destas plantas e as arbustivas com hábito decumbente rebrotam e reocupam as áreas caso não haja substituição por outras espécies que exerçam a função de recobrimento do espaço. Desta forma, preferimos utilizar o conceito da poda para o manejo utilizado.

As lianas contribuem muito para a produtividade e composição da biomassa da floresta., mas em áreas florestais muito alteradas o número de indivíduos por espécie tende a aumentar e o estudo de sua biologia toma-se muito importante para auxiliar nas indicações de formas de manejo (Morellato, 1991). A acumulação de biomassa e retenção de nutrientes estão intimamente conectados e são parâmetros óbvios no ecossistema durante o recobrimento após a perturbação (Bazzaz, 1996). Espécies de lianas e arbustos decumbentes com rápido crescimento dominam amplas áreas de capoeira baixa confirmando a estratégia de alta produtividade das etapas sucessionais iniciais. Neste fragmento, algumas espécies como Acacia paniculata. Dicella bracteosa, Celtis iguanaea e Pereskia grandifolia foram favorecidas pelas alterações decorrentes do longo período de isolamento, em especial pelo aumento da luminosidade e da temperatura. Os cipós e alguns arbustos decumbentes apresentam crescimento intenso, tendo sido observado em Celtis iguanae, por exemplo, até $3 \mathrm{~cm}$ por dia no verão (Tabanez, 1995).

A jardinagem foi o conceito desenvolvido neste trabalho para as práticas de manejo empregadas na manutenção das áreas. Algumas plantas, principalmente lianas, foram podadas em beneficio de espécies arbóreas. $\mathrm{O}$ trabalho com facão e tesoura de poda facilitou a seleção das espécies no manejo permitindo preservar as plântulas, geralmente envolvidas por cipós. Este trabalho requer um treinamento prévio dos trabalhadores de campo para o conhecimento básico das espécies, sendo muito importante o desenvolvimento de metodologias de treinamento para o 
manejo conservacionista. Um ano após o manejo, as parcelas apresentaram maior diversidade de cipós, de espécies menos "agressivas" do que as que inicialmente colonizam as capoeiras baixas.

Dentre as práticas de manejo que não foram adotadas, observou-se que teria sido importante o manejo ao redor das parcelas, através da poda das árvores e dos cipós, formando um gradiente entre a parcela em manejo e as áreas vizinhas. Ao redor das parcelas, outras bordas são formadas e devem ser tratadas. A poda das árvores presentes também seria importante para darlhes maior vigor e para sincronizar o crescimento das plantas em altura, criando maior interação e sinergia. $\mathrm{O}$ material vegetal dos cipós podados foi picado e espalhado pelo chão, formando uma densa camada de serapilheira, mas seria recomendável acumulá-lo nas faixas com cultivos agrícolas para favorecer o desenvolvimento dessas plantas.

O manejo das áreas, frequente inicialmente, garantiu a sobrevivência das mudas e plântulas nativas. $\mathrm{O}$ crescimento dos cipós e arbustos decumbentes é muito rápido e pode comprometer as mudas. $\mathrm{O}$ manejo mais intenso inicial foi sendo substituído pela jardinagem, mais seletiva e menos intensiva. Este acompanhamento deve se dar até que as áreas tenham condições de avançar na sucessão através de mecanismos e dinâmica própria, principalmente pela substituição das espécies colonizadoras dominantes por espécies do futuro, menos agressivas na ocupação e com ciclo de vida mais longo.

\section{7 - INDICADORES QUALITATIVOS}

A partir da heterogeneidade observada na coleta de dados seis meses após a instalação do experimento, avaliou-se a importância de ressaltar indicadores qualitativos para acompanhamento das áreas experimentais. Os critérios de observação foram definidos para possibilitar o estabelecimento de relações entre as características observadas e os dados quantitativos obtidos, auxiliando o diagnóstico do "estado de saúde" das parcelas. Os dados, levantados em cada subparcela de regeneração, foram agrupados por parcela, a partir da média das tendências das quatro sub-parcelas de cada área (tabela 13).

Os parâmetros observados foram : heterogeneidade dos consórcios da regeneração, concentração de cipós, domínio de determinada espécie, tipo de vizinhança, e outros organismos presentes no momento da observação. A heterogeneidade dos consórcios da regeneração representa a existência de várias espécies crescendo juntas formando núcleos de regeneração; a concentração de cipós revela se houve reocupação por rebrota, o que pode ameaçar o 
estabelecimento das plântulas e indicar a necessidade de manejo; o domínio de espécie confirma a adaptação e capacidade de ocupação de espaços abertos por certas espécies; o tipo de vizinhança influencia as áreas por promover maior ou menor sombreamento, exposição ao vento e proximidade à fonte de propágulos; os organismos presentes no momento da observação fazem parte da biodiversidade local e representam uma pequena amostra de elementos não-arbóreos das capoeiras baixas.

Tabela 13. Indicadores semi-qualitativos para avaliação das áreas experimentais. Os resultados representam a média por parcela, sete meses após a instalação do experimento, nas situações de borda e interior em cada tratamento: 1, poda de cipós e plantio agrícola, 2, poda de cipós e plantio agroflorestal e 3, testemunha.

\begin{tabular}{|c|c|c|c|c|c|}
\hline PARCELA & \begin{tabular}{|l|} 
HETEROGENEIDA- \\
DE DOS \\
CONSÓRCIOS \\
\end{tabular} & $\begin{array}{l}\text { CONCEN- } \\
\text { TRAÇĀO } \\
\text { DE CIPÓS } \\
\end{array}$ & $\begin{array}{l}\text { DOMÚNIO DE } \\
\text { ESPÉCIE }\end{array}$ & $\begin{array}{l}\text { OUTROS } \\
\text { ORGANISMOS }\end{array}$ & VIZINHANÇA \\
\hline \multicolumn{6}{|c|}{ TRATAMENTO AGRÍCOLA - BORDA } \\
\hline 1 & Homogênea & Média & $\begin{array}{l}\text { Sim } \\
\text { (Celtis iguanae) }\end{array}$ & Tocas de tatú & $\begin{array}{l}\text { Capoeira baixa e } \\
\text { bambuzal }\end{array}$ \\
\hline 2 & Homogênea & Média & $\begin{array}{l}\text { Sim } \\
\text { (Solanum sp. })\end{array}$ & $\begin{array}{l}\text { Fonnigas e } \\
\text { fungos }\end{array}$ & Bambuzal \\
\hline 3 & Homogênea & Alta & Não & & Capoeira baixa \\
\hline 4 & Homogênea & Alta & $\begin{array}{l}\text { Sim, cipó não } \\
\text { identificado }\end{array}$ & - & Capoeira baixa \\
\hline 5 & Homogênea & Média & Não & Fungos & Capoeira baixa \\
\hline \multicolumn{6}{|c|}{ TRATAMENTO AGROFLORESTAL - BORDA } \\
\hline 1 & Heterogênea & Média & $\begin{array}{l}\text { Sim } \\
\text { (Ricinus comunis) }\end{array}$ & Fonnigas & $\begin{array}{l}\text { Capoeira baixa e } \\
\text { bambuzal }\end{array}$ \\
\hline 2 & | Heterogênea & Média & Não & Tocas de tatú & Capoeira alta \\
\hline 3 & | Homogênea & Alta & Sim, gramíneas & & Capoeira alta \\
\hline 4 & Homogênea & Média & Sim, gramineas & & Capoeira baixa \\
\hline 5 & Homogênea & Alta & Sim, gramineas & & Capoeira baixa \\
\hline \multicolumn{6}{|c|}{ TRATAMENTO TESTEMUNHA - BORDA } \\
\hline 1 & Homogênea & Alta & $\begin{array}{l}\text { Sim } \\
\text { (Celtis iguanae) }\end{array}$ & - & Capoeira baixa \\
\hline 2 & Homogênea & Alta & $\begin{array}{l}\text { Sim } \\
\text { (Celtis iguanae) }\end{array}$ & Insetos & $\begin{array}{l}\text { Capoeira baixa e } \\
\text { borda }\end{array}$ \\
\hline 3 & Homogênea & Alta & $\begin{array}{l}\text { Sim, } \\
\text { (Acacia paniculata) }\end{array}$ & - & Capoeira baixa \\
\hline 4 & Homogênea & Média & Sim, gramíneas & - & Capoeira baixa \\
\hline 5 & Heterogênea & Alta & Não & - & $\begin{array}{l}\text { Borda e } \\
\text { bambuzal }\end{array}$ \\
\hline
\end{tabular}




\begin{tabular}{|c|c|c|c|c|c|}
\hline PARCELAS & $\begin{array}{l}\text { HETEROGENEIDA- } \\
\text { DE DOS } \\
\text { CONSÓRCIOS } \\
\end{array}$ & $\begin{array}{l}\text { CONCEN- } \\
\text { TRAÇĀOO } \\
\text { DE CIPÓS } \\
\end{array}$ & $\begin{array}{l}\text { DOMÉNIO DE } \\
\text { ESPÉCIE }\end{array}$ & $\begin{array}{l}\text { OUTROS } \\
\text { ORGANISMOS }\end{array}$ & VIZINHANÇA \\
\hline \multicolumn{6}{|c|}{ TRATAMENTO AGRÍCOLA - INTERIOR } \\
\hline 1 & Heterogênea & Alta & \begin{tabular}{|l|} 
Sim \\
(Celtis iguanae e \\
Solanum sp.) \\
\end{tabular} & Formigas & Capoeira baixa \\
\hline 2 & Heterogênea & Média & Não & Fungos & $\begin{array}{l}\text { Capoeira alta e } \\
\text { baixa }\end{array}$ \\
\hline 3 & Heterogênea & Média & Não & Pássaros & Capoeira alta \\
\hline 4 & Heterogênea & Média & $\begin{array}{l}\text { Sim, cipó não } \\
\text { identificado }\end{array}$ & Tocas & $\begin{array}{l}\text { Capoeira alta e } \\
\text { bambuzal }\end{array}$ \\
\hline 5 & Homogênea & Alta & $\mid \begin{array}{l}\text { Sim } \\
\text { (Celtis iguanae) }\end{array}$ & - & Capoeira baixa \\
\hline \multicolumn{6}{|c|}{ TRATAMENTO AGROFLORESTAL - INTERIOR } \\
\hline 1 & Homogênea & Alta & \begin{tabular}{|l} 
Sim \\
(Celtis iguanae)
\end{tabular} & Tocas & Capoeira baixa \\
\hline 2 & Heterogênea & Média & \begin{tabular}{|l} 
Sim \\
(Solanum Sp.)
\end{tabular} & Formigas saúvas & Capoeira baixa \\
\hline 3 & Homogênea & Média & Sim, gramineas & Formigas & Capoeira baixa \\
\hline 4 & Homogênea & Baixa & Não & Borboletas & $\begin{array}{l}\text { Capoeira alta e } \\
\text { baixa }\end{array}$ \\
\hline 5 & Heterogênea & Baixa & \begin{tabular}{|l} 
Sim \\
(Solanum sp.)
\end{tabular} & Formigas e tocas & Bambuzal \\
\hline \multicolumn{6}{|c|}{ TRATAMENTO TESTEMUNHA - INTERIOR } \\
\hline 1 & Heterogênea & Média & Não & Fezes de veado & Capoeira alta \\
\hline 2 & Homogênea & Alta & $\begin{array}{l}\text { Sim, } \\
\text { (Merostachis sp.) }\end{array}$ & - & Capoeira alta \\
\hline 3 & Homogènea & Alta & \begin{tabular}{|l} 
Sim, \\
(Merostachis sp.)
\end{tabular} & - & Capoeira alta \\
\hline 4 & Homogênea & Média & Não & - & $\begin{array}{l}\text { Capoeira alta e } \\
\text { baixa }\end{array}$ \\
\hline 5 & Homogênea & Alta & \begin{tabular}{|l} 
Sim \\
(Acacia paniculata)
\end{tabular} & Borboletas & Capoeira alta \\
\hline
\end{tabular}

Pode-se dizer que, de forma geral, as áreas nas bordas e no interior do fragmento não se diferenciam significativamente quanto aos parâmetros observados. Apresentam similaridades principalmente quanto à porcentagem de cipós, que vai de média à alta em ambas as situações em todos tratamentos e à dominância de determinada espécie, com domínio principalmente de espécies de cipós, arbustos decumbentes e/ou gramíneas em quase todas as áreas. Os organismos encontrados representam um pouco da biodiversidade local com presença observada em diversas 
parcelas. $\mathrm{O}$ efeito da posição das áreas, na borda ou no interior, promove maior diferença quanto à vizinhança, que nas áreas de interior é em maior parte de capoeira alta e nas bordas de capoeira baixa, o que determina o grau de sombreamento das parcelas e a proximidade das fontes de propágulos. A maior heterogeneidade dos consórcios de plântulas nas áreas de interior pode indicar que maior número de espécies com ritmos de crescimento distintos estão presentes no mesmo espaço. Evidências sugerem que os agregados de espécies podem ser um dos critérios para avaliar o recobrimento de ecossistemas no processo de reabilitação (Cairns, 1986).

Foi observado que algumas plântulas recrutadas (ex. Croton floribundus) apresentaram arquitetura modificada, com pouco tecido de sustentação. Percebe-se que estas plantas seguem a estratégia dos cipós e se sustentam sobre as espécies herbáceas ou outros cipós. Muitas vezes a densidade de cipós "deita" as plântulas com seu peso, homogeneizando o "dossel" a uma mesma altura. A arquitetura arbórea é utilizada para a análise da floresta tropical com base na forma e nas modificações; a diagnose do "estado arquitetural" dos componentes ou elementos fornecem parâmetros para o estudo de eco-unidades (Oldeman, 1983b). Os padrões arquitetônicos das ecounidades e das árvores de um fragmento florestal diferenciam-se muito das florestas conservadas e a tendência ao rebaixamento do dossel nas composições secundárias parece ser o rumo dos fragmentos florestais.

Esta avaliação, feita através de critérios semi-qualitativos e comparativos, auxiliou a visualização das estratégias naturais de colonização das áreas e contribuiu para uma melhor compreensão da dinâmica em curso. Foi possivel obter informações quanto às estratégias de regeneração e recomposição agregando observações muitas vezes não observadas em pesquisas de campo. Os indicadores eleitos podem ser facilmente trabalhados por pessoas treinadas, contribuindo para a elaboração de um roteiro para diagnóstico expedito de áreas de fragmentos manejadas para recuperação e para o treinamento de trabalhadores de campo.

\section{8 - PROPOSTAS PARA A CONTINUIDADE DO MANEJO}

A grande heterogeneidade ambiental desencadeou a formação acelerada de eco-unidades nas áreas experimentais a partir de sítios com características peculiares, como tipo de vizinhança, árvores presentes ao redor, mancha de solo e posição em relação à incidência de luz. Grande heterogeneidade micro-ambiental nas clareiras resulta de diferenças no impacto original, tamanho,

orientação e estrutura da comunidade remanescente (Oldeman, 1983b), além da temperatura do 
solo e do ar, umidade e velocidade do vento, que estão associados com a intensidade de luz (Bazzaz, 1996). As eco-unidades formadas em áreas heterogêneas devem ser manejadas diferenciadamente, segundo suas características de desenvolvimento.

Alguns critérios podem determinar classes para capoeiras baixas, contribuindo para o diagnóstico e a proposição de manejo para recuperação destas áreas. Os critérios principais considerados para a avaliação das áreas um ano após a intervenção foram: o nível de luminosidade, a densidade da regeneração natural e a dominância de espécies com comportamento "agressivo" (tabela 14). Cada critério foi avaliado comparativamente nas categorias : alto, médio e baixo; cada categoria representa uma pontuação, que somadas indicam a classe a que a parcela pertence. As "classes de eco-mosaicos" foram determinadas para facilitar a avaliação da necessidade de continuidade de manejo nas áreas experimentais e para recomendação de manejo (tabela 15).

Tabela 14. Critérios para determinar classes de capoeiras baixas. Cada área deve ser pontuada por critério e, com a soma dos pontos, entra-se na tabela 15 .

\begin{tabular}{|c|c|c|}
\hline $\begin{array}{c}\text { CRITÉRIO 1 } \\
\text { Nível de luminosidade }\end{array}$ & $\begin{array}{c}\text { CRITÉRIO 2 } \\
\text { Densidade da regeneração } \\
\text { natural }\end{array}$ & $\begin{array}{c}\text { CRITÉRIO 3 } \\
\text { Dominância de espécie com } \\
\text { comportamento agressivo }\end{array}$ \\
\hline Alto $=1$ & Alta $=3$ & Alta $=1$ \\
\hline Médio $=2$ & Média $=2$ & Média $=2$ \\
\hline Baixo $=3$ & Baixa $=1$ & Baixa $=3$ \\
\hline
\end{tabular}

Tabela 15. Classes de capoeira baixa e sugestões de manejo segundo a classificação das áreas.

\begin{tabular}{|l|l|l|l|l|}
\hline $\begin{array}{l}\text { SOMA } \\
\text { DOS } \\
\text { PONTOS }\end{array}$ & CLASSE & $\begin{array}{l}\text { NECESSIDADE } \\
\text { DE MANEJO }\end{array}$ & $\begin{array}{l}\text { TIPO DE } \\
\text { INTERVENÇÃO }\end{array}$ & MANEJO RECOMENDADO \\
\hline 8 ou 9 & I & Opcional & Manejo da regeneração & $\begin{array}{l}\text { Enriquecimento com nativas; } \\
\text { manejo das espécies existentes }\end{array}$ \\
\hline 5 a 7 & II & Importante & $\begin{array}{l}\text { Jardinagem com poda } \\
\text { de cipós e plantio } \\
\text { opcional }\end{array}$ & $\begin{array}{l}\text { Plantio de florestais e frutíferas } \\
\text { nativas e espécies agrícolas } \\
\text { tolerantes à sombra }\end{array}$ \\
\hline 3 ou 4 & III & Imprescindível & Poda dos cipós e plantio & $\begin{array}{l}\text { Plantio de espécies agrícolas e } \\
\text { arbóreas de crescimento rápido }\end{array}$ \\
\hline & BORDA & Imprescindível & Poda dos cipós e plantio & $\begin{array}{l}\text { Plantio de espécies arbóreas de } \\
\text { crescimento rápido, frutíferas e } \\
\text { agricolas }\end{array}$ \\
\hline
\end{tabular}


A avaliação de cada área experimental feita com base nos critérios observados em campo indicou a necessidade e o tipo de manejo a ser empregado como continuidade nas áreas. $\mathbf{O}$ resultado aponta que a maior parte das parcelas encontra-se na classe II e não requer mais um manejo tão intensivo (tabela 16). As áreas mais abertas, com pouca regeneração natural, alto nível de luminosidade e alta dominância de espécies com comportamento agressivo (classe III e áreas de borda) necessitam ainda um manejo intensivo, com poda de cipós e arbustos decumbentes que pode ser acompanhado por plantio de espécies arbóreas de rápido crescimento e espécies agrícolas para compensação dos custos de manejo. As agrícolas são de ciclo curto e saem logo do sistema e, com o manejo das culturas agrícolas estarão sendo monitoradas as áreas. Quando as áreas se encontram nas classes I e II, o manejo necessário é menos intensivo e pode não mais precisar de plantio.

Tabela 16. Número de áreas experimentais dos tratamentos 1, plantio agrícola e 2, plantio agroflorestal em cada "classe de capoeira baixa” um ano após a intervenção.

\begin{tabular}{|l|ll|l|}
\hline PARCELAS & CLASSE I & |CLASSE II & CLASSE III \\
\hline BORDA & 1 & 13 & 6 \\
\hline INTERIOR & 4 & 15 & 1 \\
\hline
\end{tabular}

Este trabalho representou uma versão preliminar da possibilidade da utilização de sistemas agroflorestais para a recuperação de eco-mosaicos degradados em fragmentos florestais. Novas versões de sistemas agroflorestais devem ser aprimoradas a partir das lições obtidas nas falhas e acertos da concepção, manejo e composição de espécies deste experimento. Outras espécies florestais nativas, frutíferas e culturas agrícolas devem ser experimentadas em diferentes situações. As espécies frutíferas são indicadas para as áreas de borda, podendo ser uma boa altemativa para sua recuperação, funcionando como uma zona tampão de transição entre o fragmento e as atividades agrícolas vizinhas. Podem propiciar um gradiente na estratificação entre a cultura agrícola adjacente ao fragmento e a floresta, o que promove uma aerodinâmica favorável (Emst Götsch, comunicação pessoal). A zona tampão constituída de agrofloresta poderia resolver os conflitos criados pelo efeito de borda nas florestas (Gajaseni et al., 1996). Esta faixa pode reduzir o efeito da insolação e vento direto sobre as bordas dos fragmentos e minimizar os impactos negativos desta abrupta fronteira. Pelo que foi constatado neste trabalho, a regeneração natural pode ser facilitada por ações humanas com intervenções simples, devendo-se investigar 
espécies prioritárias para o enriquecimento do fragmento e variedades agrícolas que possam trazer retomo econômico.

\section{CONCLUSÕES}

As predições desta pesquisa foram confirmadas em parte, devendo-se tecer algumas considerações sobre os processos observados. $\mathrm{O}$ manejo aplicado contribuiu para a recuperação das capoeiras baixas promovendo maior densidade de regeneração natural nas áreas com tratamento 1 (2233 plântulas/ha) e tratamento 2 (2091 plântulas/ha) do que nas áreas testemunhas (580 plântulas/ha) em um ano. Observou-se, no entanto, que este aumento deu-se principalmente pelo efeito da poda dos cipós e arbustos decumbentes, o que representou uma etapa do manejo em ambos os tratamentos. A densidade de plântulas recrutadas ultrapassou a densidade obtida em plantio convencional de mudas arbóreas (1666 plantas/hectare). Esta conclusão representa um avanço para a recuperação de fragmentos florestais, indicando que a otimização dos processos de regeneração natural são mais importantes, eficazes e baratos do que o plantio de mudas.

As espécies arbóreas plantadas no tratamento 2 desenvolveram-se bem apresentando taxa de sobrevivência de $85 \%$. As culturas agrícolas foram bio-indicadoras da heterogeneidade das áreas experimentais, apresentando crescimento e produção desuniforme e diferenciada entre as parcelas. A produção agrícola total foi baixa, com muitos frutos apresentando doenças. A receita bruta representou $10 \%$ dos custos totais dos tratamentos implantados e a compensação dos custos não foi obtida com as culturas agrícolas testadas. Experimentos utilizando outras espécies agrícolas, plantadas e manejadas de acordo com a heterogeneidade e dinâmica das eco-unidades observadas neste trabalho, devem ser realizados para a busca da redução de custos na recuperação de fragmentos florestais. 


\section{CAPÍTULO III}

\section{DINÂMICA DE CAPOEIRAS BAIXAS NA}

\section{RECUPERAÇÃO DE UM FRAGMENTO FLORESTAL}

"O papel crítico que as florestas vão exercer no futuro em nosso planeta ordena que nós intensifiquemos nossos esforços para entender este enigmático e precioso ecossistema natural"

Bazzaz, 1996

\section{INTRODUÇÃO}

A sucessão secundária é o processo que ocorre em áreas previamente ocupadas por uma comunidade vegetal após um impacto natural ou antrópico. Pode ser definida como um mecanismo de auto-renovação das florestas tropicais por meio da cicatrização de locais perturbados, que ocorrem a cada momento em diferentes pontos da mata (Kageyama $\&$ Castro, 1988). Existem diversos conceitos e interpretações para a sucessão, principalmente por se tratar de um fenômeno ecológico em que muitas variáveis do ecossistema estão envolvidas, incluindo organismos, interações, ambientes, impactos, processos e dinâmicas em escalas espaciais e temporais.

As florestas tropicais são dinâmicas e estão sob contínuas mudanças, formando mosaicos em diversos estágios sucessionais. As peças dos mosaicos podem ser identificadas por ecounidades ou unidades de regeneração que são definidas como "unidades espaciais da vegetação que iniciam seu crescimento sobre uma superficie bem definida, seguindo o mesmo processo de desenvolvimento" (Oldeman, 1983b;1990). Como um "baralho de eco-unidades", a floresta assume um movimento "caleidoscópico", com dinâmica constante e imprevisível (Prof. Roelof Oldeman, comunicação pessoal). Os eco-mosaicos são "ecossistemas que ocupam uma classe de sítios similares, compostos por vários tipos de eco-unidades que interagem e estão em distintas fases de desenvolvimento" (Rossignol et al., 1998). A diversidade das florestas tropicais toma 
possível uma enorme variedade de combinações de espécies, que aliada às variações climáticas e impactos naturais e antrópicos, toma a dinâmica da sucessão um fenômeno imprevisível.

A dinâmica em fragmentos florestais é influenciada por fatores decorrentes da fragmentação e desenvolve-se com características diferenciadas dos processos sucessionais observados em florestas conservadas ou pouco perturbadas. A grande intensidade e freqüência de perturbações nos fragmentos florestais desencadeia a transformação acelerada de ecounidades maduras em eco-unidades iniciais. Eventos destrutivos - "evento zero" (Vester, 1997) ocorrem com maior freqüência a partir de forças antrópicas diretas ou naturais decorrentes da fragmentação. A taxa de criação de clareiras e seu preenchimento são determinados por fatores intrínsecos e extrínsecos, em que a freqüência e severidade de perturbações direciona a evolução de várias histórias de vida das espécies participantes no processo de recobrimento (Bazzaz, 1996). Há evidências de que a sucessão em pequenos fragmentos florestais na região de planalto do Estado de São Paulo não recupera a diversidade da floresta nas eco-unidades pouco diversificadas, com baixa densidade de indivíduos arbóreos pioneiros e super-abundância de cipós e trepadoras (Viana \& Tabanez, 1996).

As clareiras grandes e bordas de fragmentos de floresta mesófila semidecídua apresentam padrões de colonização com alta densidade de cipós e arbustos decumbentes. $\mathbf{O}$ baixo investimento na auto-sustentação permite um crescimento vigoroso aos cipós que aumentam a mortalidade de árvores e retardam seu crescimento (Putz, 1983). Fatores que limitam a regeneração florestal natural e o estabelecimento de árvores são considerados "barreiras" (Nepstad et al., 1998) e podem incluir : baixa disponibilidade de propágulos, predação de sementes, ausência de microhabitats adequados para estabelecimento de plântulas, baixa disponibilidade de nutrientes do solo, fogo e seca sazonal (Parrota, 1993). Em fragmentos florestais as espécies mais tardias podem desaparecer, a qualidade do solo piorar, os simbiontes especializados do solo desaparecerem e o habitat ficar retido num estado de contínua e "arrastada" sucessão secundária (Schellas \& Greenberg, 1996). Modelos baseados na compreensão da mudança de recursos e a resposta das espécies às mudanças têm sido usados para predizer a dinâmica florestal (Bazzaz, 1996).

Nas capoeiras baixas e nos eco-mosaicos em fase de desenvolvimento inicial, a arquitetura é descontínua e espalhada em diversas pequenas eco-unidades onde as funções anteriores de filtro ao "stress" estão desorganizadas (Rossignol et al., 1998). As clareiras grandes tendem a fragmentar-se rapidamente em eco-unidades pequenas; porém, os cipós exercem um efeito de fusão prematura de eco-unidades em fase de "iniciação bloqueada" e transformam o 
eco-mosaico em uma "eco-unidade funcional", homogeneizando padrões do dossel sob um mesmo regime de impacto ambiental (Oldeman, 1990).

A regeneração natural permite uma análise efetiva para diagnosticar o estado de conservação da floresta e sua dinâmica. A densidade e diversidade de plântulas pode revelar aspectos da sucessão, indicando as estratégias de recomposição natural e o potencial das árvores presentes. $O$ banco de propágulos (Oldeman, 1990) determina a potencialidade de regeneração dos sítios. A dinâmica das eco-unidades deve ser melhor compreendida para embasar o diagnóstico e o manejo para recuperação e conservação dos fragmentos florestais.

\section{MATERIAL E MÉTODOS}

\section{0 - ÁREA E CARACTERIZAÇÃO DO LOCAL DE ESTUDO}

Ver capítulo 2.

\section{1 - REGENERAÇÃO NATURAL}

A riqueza de espécies da regeneração natural nas capoeiras baixas do fragmento florestal foi avaliada para diagnosticar a dinâmica após os tratamentos testados. Foram instaladas 30 parcelas, 15 próximas às bordas e 15 no interior do fragmento, nas quais foram aplicados três tratamentos:

(i) poda dos cipós e plantio de espécies agrícolas

(ii) poda dos cipós e plantio de espécies agrícolas e arbóreas

(iii) testemunha

As parcelas têm tamanho diferenciado de acordo com o tamanho das áreas naturais de capoeira baixa no fragmento. Totalizam $6100 \mathrm{~m}^{2}$, variando de 154 a $333 \mathrm{~m}^{2}$. Cada tratamento tem 10 repetições, 5 na borda e 5 no interior do fragmento. Em cada parcela foram instaladas quatro sub-parcelas de $3 \times 3 \mathrm{~m}\left(9 \mathrm{~m}^{2}\right)$, cada uma na direção de um ponto cardeal, distantes aproximadamente 2 metros das bordas das parcelas. Em cada sub-parcela foram inventariados todos os individuos de espécies arbustivas e arbóreas com altura $\geq 50$ centímetros, totalizando $1080 \mathrm{~m}^{2}$ de área amostral. A regeneração natural foi avaliada em três momentos : um mês, sete meses e um ano após a instalação dos tratamentos. As plântulas foram coletadas para a identificação, que foi feita no departamento de Botânica da ESALQ/USP. As exsicatas foram catalogadas e montou-se um "álbum de campo" para facilitar futuras pesquisas e identificação de plântulas no campo. 
Foi construída uma matriz de dados de presença e ausência de espécies em cada subparcela amostrada. Para verificar a similaridade florística entre as parcelas foi utilizada a técnica de classificação através do índice de Jaccard e a construção do dendrograma baseado na média de grupo (UPGMA). Para a ordenação dos dados foi utilizado o método de análise das coordenadas principais (PCO). Para a classificação foram usados os programas “Coef” e "Cluster" e na análise de ordenação o programa "Ord”, todos presentes no pacote FITOPAC, de autoria de G. J. Shepherd (UNICAMP).

\section{2 - INVENTÁRIO DAS ÁRVORES (DAP $\geq 5 \mathrm{~cm}$ ) EXISTENTES NAS ÁREAS}

No momento de instalação do experimento, foi feito um inventário das árvores com DAP $\geq 5 \mathrm{~cm}$ presentes nas 30 parcelas de capoeira baixa. As árvores pré-existentes nas áreas foram marcadas e tiveram o DAP medido. Após um ano, foi feito outro inventário nas mesmas áreas com nova medição das árvores pré-existentes e a marcação e medição das que foram recrutadas no período. As árvores foram coletadas para identifícação, feita no Departamento de Botânica da ESALQ/USP. Assim como para as plântulas da regeneração natural, foi construída uma matriz de dados de presença e ausência de espécies nas parcelas e para verificar a similaridade florística entre as parcelas utilizou-se a técnica de classificação através do índice de Jaccard e a construção do dendrograma baseado na média de grupo (UPGMA). Os mesmos programas ("Coef", "Cluster" e "Ord") foram utilizados para a ordenação dos dados, a classificação e a análise de ordenação, todos presentes no pacote FITOPAC, de autoria de G. J. Shepherd (UNICAMP).

\section{3 - O MANEJO}

Inicialmente foi feito um diagnóstico das 30 parcelas experimentais de capoeira baixa nas quais foram avaliados aspectos como o tipo de vizinhança, fisionomia, altura do dossel e dominância de espécies. A intervenção nas áreas, com os tratamentos 1 e 2 , compreendeu uma poda drástica dos cipós e arbustos decumbentes, que foram picados e espalhados sobre o solo, e o plantio subsequente. No tratamento 1 foram plantadas espécies agrícolas : abóbora menina (Cucurbita moschata), abóbora seca (Cucurbita pepo), abóbora moranga (Cucurbita maxima), pepino (Cucumis sativus), maxixe (Cucumis anguria), e chuchu (Sechium eduli), e no tratamento 2, as mesmas agrícolas com as arbóreas : aroeira pimenteira (Schinus terebenthifolius Raddi), canafistula (Peltophorum dubium. (Spreng.)Taub.), guapuruvu (Schizolobium parahyba (Vell.) 
Blake), ipê felpudo (Zeyheria tuberculosa (Vell.) Bur), jequitibá rosa (Cariniana legalis (Mart.) Kuntze), mutambo (Guazuma ulmifolia Lam) e pau viola (Cytharexylum myrianthum Cham). Aos sete meses após o manejo foi feita uma jardinagem nas parcelas, com corte de cipós ao redor das mudas plantadas e das plântulas recrutadas, que foi repetida seis meses depois. A jardinagem é o conceito desenvolvido neste trabalho utilizado para o manejo seletivo, em que são podadas algumas plantas em benefício de outras, facilitando a sucessão.

\section{RESULTADOS E DISCUSSÃO}

\section{1 - REGENERAÇÃO NATURAL}

Foi observada maior densidade de regeneração natural nas parcelas sob os tratamentos 1 e 2 (figura 12), indicando que o efeito do manejo com poda de cipós e plantio foi benéfico para alavancar a sucessão natural (tabela 20).

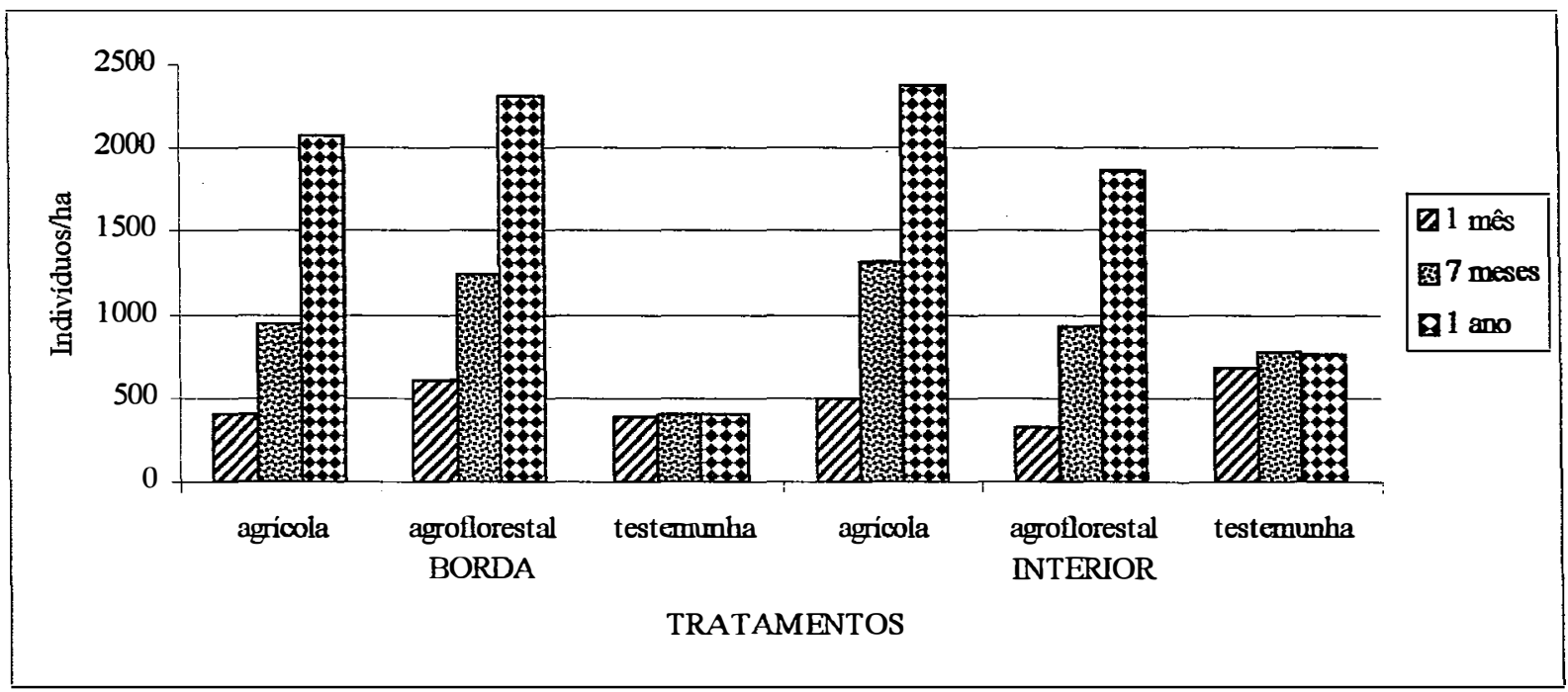

Figura 12. Densidade de plântulas $(\mathrm{h} \geq 50 \mathrm{~cm})$ recrutadas nos tratamentos 1 , poda de cipós e plantio agrícola, 2, poda de cipós e plantio agroflorestal e 3, testemunha, em 1 mês (T1) após a instalação do experimento, 7 meses (T2) e 1 ano (T3). 
A riqueza de espécies arbóreas recrutadas nas áreas experimentais foi alta, totalizando 56 espécies nas áreas de borda e 67 espécies nas áreas de interior. As parcelas apresentaram grande variação quanto ao número de espécies recrutadas (tabela 17), o que expressa a heterogeneidade das capoeiras baixas. A heterogeneidade observada pode ser resultado de condições diferenciadas das parcelas relativas a : vizinhança, que determina a chuva de sementes e o sombreamento; posição em relação ao trajeto do sol e espécies dominantes presentes antes da intervenção. Estes fatores foram avaliados comparativamente entre as parcelas experimentais antes da intervenção e foi observada a diferença. As clareiras apresentam geralmente uma alta heterogeneidade interna (Martinez-Ramos, 1985) e as capoeiras baixas, assim como as clareiras, assemelham-se umas às outras em estrutura e fisionomia mas apresentam diferenças quanto à composição e dinâmica.

Tabela 17. Número médio, mínimo e máximo de espécies arbóreas recrutadas por parcela (de 154 a $333 \mathrm{~m}^{2}$ ) e por hectare (entre parênteses) em um ano nos tratamentos 1, poda de cipós e plantio agrícola, 2, poda de cipós e plantio agroflorestal e 3, testemunha.

\begin{tabular}{|l|l|l|l|l|l|l|}
\hline TRATAMENTO & \multicolumn{3}{|c|}{ Borda } & \multicolumn{3}{c|}{ Interior } \\
\hline & médio & mínimo & máximo & médio & mínimo & máximo \\
\hline 1- Agrícola & $13(590,9)$ & $7(318)$ & $28(1272,7)$ & $12,6(572,7)$ & $7(318)$ & $18(818)$ \\
\hline 2- Agroflorestal & $11(500)$ & $4(181,8)$ & $19(863,6)$ & $14(636,3)$ & $10(454,5)$ & $17(772,7)$ \\
\hline 3- Testemunha & $3(136,3)$ & $1(45,4)$ & $7(318)$ & $5,6(254,5)$ & $3(136,3)$ & $10(454,5)$ \\
\hline
\end{tabular}

Não houve diferença significativa quanto à riqueza de espécies entre as áreas de borda e de interior mas, de forma geral, as parcelas mostraram-se muito variáveis quanto à composição de espécies arbóreas recrutadas $(\mathrm{h} \geq 50 \mathrm{~cm})$. 0 dendrograma construído para as espécies da regeneração natural nas parcelas experimentais (figura 13) apresenta a formação de apenas um grupo de parcelas com similaridade florística, considerando-se $50 \%$ no coeficiente de Jaccard. Ao considerar $25 \%$ de Jaccard, outros grupos se formam, mas são poucos em relação ao total de parcelas. Os grupos formados não se relacionam com o tratamento aplicado nem com a posição espacial no fragmento, mas principalmente com a situação de borda ou interior. A formação de poucos grupos com similaridade florística deve-se à alta variabilidade em relação à composição de espécies entre as parcelas, evidenciando mais uma vez a grande heterogeneidade, fruto da dinâmica intensiva do processo de fragmentação dos eco-mosaicos e eco-unidades no fragmento. 
Por causa da grande heterogeneidade ambiental, plasticidade individual e padrões de dispersão, é difícil predizer a seqüência de espécies na ocupação de clareiras (Bazzaz, 1996).

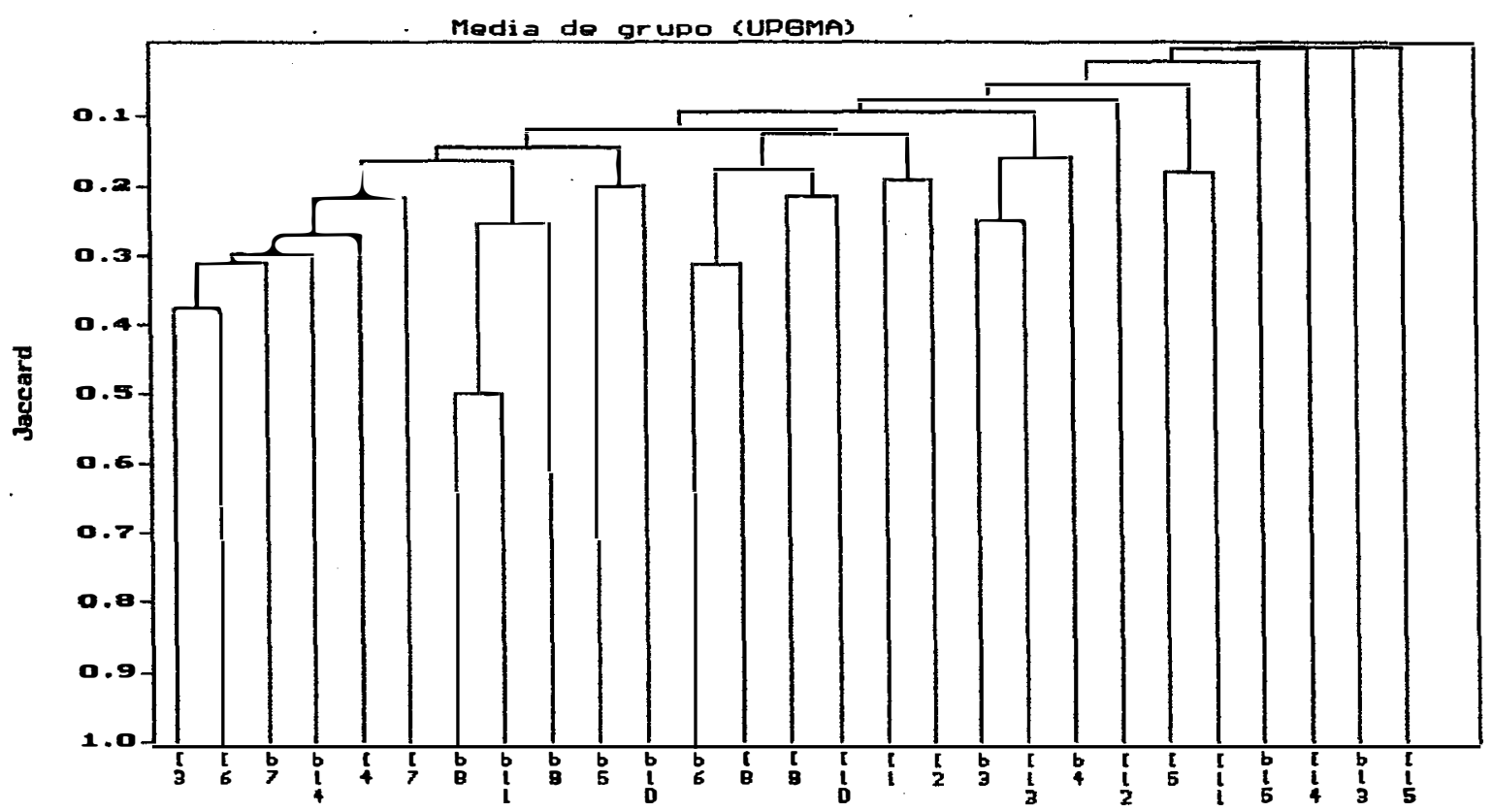

Figura 13. Dendrograma relativo às espécies arbóreas recrutadas $(\mathrm{h} \geq 50 \mathrm{~cm})$ apresentando a similaridade florística entre as parcelas, localizadas nas bordas e no interior do fragmento, sob os tratamentos 1 , poda de cipós e plantio agrícola $(b 3, b 7, b 8, b 10, i 2, i 3$, i7, i8 e i9), 2, poda de cipós e plantio agroflorestal (b2, b4, b5, b6, b9, i1, i4, i5, i6 e i10) e 3, testemunha (b11, b13, b14, b15, il1, i12, i13, i14 e i15).

As espécies recrutadas nos três tratamentos representam todos os grupos ecológicos, dos pioneiros aos mais tardios. Entre as plântulas, a rapidez de crescimento, o ciclo de vida e as características ecológicas vão diferenciá-las, favorecendo algumas e eliminando outras, de acordo com as estratégias de adaptação e a interação com as condições locais. Algumas têm crescimento rápido e ocupam imediatamente as áreas abertas, enquanto outras, de crescimento lento, permanecem plântulas à espera de condições ideais para seu crescimento. As mudanças temporais na composição e dominância de espécies ao longo da sucessão têm sido traçadas como o resultado da interação competitiva dentro de populações bem como entre populações de espécies (Gómez-Pompa\& Vásquez-Yanes, 1976). Tais interações baseiam-se nas estratégias de 
regeneração e crescimento das diferentes espécies, que lhes confere a capacidade de sucesso na utilização de recursos sob as diferentes condições apresentadas ao longo do tempo.

\subsection{1. - ESPÉCIES RECRUTADAS}

A riqueza de espécies da regeneração natural resulta da interação dos fatores abióticos envolvidos com a resposta adaptativa das espécies que se instalam. As espécies arbóreas e arbustivas recrutadas em um ano (tabela 20) representam um "termômetro" da dinâmica das capoeiras baixas, com e sem manejo. Tanto no interior como na borda, duas espécies pioneiras ocorreram em alta densidade: Solanum granuloso-leprosum (fumo bravo), e Croton floribundus (capixingui). Estas espécies apresentaram um sucesso reprodutivo em relação às outras. A época de frutifícação do Croton floribundus, árvore com dispersão autocórica presente em diversos trechos deste fragmento, coincidiu com o manejo das áreas, contribuindo para o recrutamento de alta densidade de indivíduos desta espécie; e sementes do Solanum granuloso-leprosum provavelmente faziam parte do banco de sementes de algumas áreas experimentais.

$O$ revolvimento do solo na ocasião do plantio provavelmente estimulou o banco de sementes do solo, trazendo sementes que estavam enterradas para a camada superficial. Provavelmente uma parte das sementes germinadas são fotoblásticas positivas e respondem à mudança dos tipos de luz incidente. As características de dormência e longevidade de muitas sementes de espécies pioneiras, por exemplo, estão associadas à mesma função ecológica de manutenção de um banco de sementes no solo até que uma clareira grande possibilite a germinação por aumento na temperatura ou na intensidade de luz (vermelho e vermelho longo) (Kageyama \& Viana, 1989). Este fator é muito importante quando se deseja otimizar a regeneração natural em áreas para recuperação, podendo-se direcionar o manejo do solo. $\mathbf{O}$ banco de sementes tem um fluxo dinâmico: novas sementes chegam, algumas germinam e formam o. banco de plântulas, algumas morrem e outras permanecem cobertas no solo. A persistência varia entre as espécies e a distribuição no espaço é resultado da interação de diversos fatores como a localização, a heterogeneidade do ambiente físico e os padrões de dispersão, predação e deterioração das sementes (Bazzaz, 1996). A arquitetura do mosaico florestal e a distribuição de árvores matrizes determinam a composição do banco de propágulos nas eco-unidades (Oldeman, 1990), sendo a chuva de sementes fator de extrema importância para a recomposição de áreas abertas ou perturbadas.

As espécies recrutadas têm características ecológicas distintas e exercem funções específicas nos ecossistemas. A diferenciação de nichos através da variação de microsítios numa 
clareira aumenta o número de espécies que podem coexistir numa floresta (Clark \& Clark, 1987). A variação da composição de espécies nas sub-parcelas de uma mesma parcela confírma a diversidade de espécies a partir da heterogeneidade de nichos. A tendência da sucessão florestal em fragmentos também pode ser avaliada pela análise da presença de árvores do presente e do futuro: os fragmentos em estado de equilíbrio são caracterizados por um processo de renovação que permite manter a riqueza específica do grupo de árvores do futuro, enquanto os fragmentos em estado de empobrecimento, que indicam uma sucessão regressiva, apresentam menos árvores do futuro presentes (Metzger, 1998).

Uma consideração muito importante para a interpretação da diversidade é a densidade na distribuição natural das espécies que varia muito nas florestas tropicais, existindo as espécies mais comuns, que podem atingir mais de 100 indivíduos por hectare, e as mais raras, com densidade de até uma árvore a cada 50 hectares (Kageyama \& Gandara, 1993). A dinâmica das populações é base para o entendimento da diversidade das florestas e das espécies em cada grupo ecológico. As espécies foram classificadas em grupos ecológicos usando critérios de diversos pesquisadores (Budowski, 1965; Denslow, 1980; Whitmore, 1991; Martinez-Ramos, 1985; Oldeman, 1990; Viana, 1989; Götsch, 1995). A maior parte dos agrupamentos considera como fator chave a resposta à luz, sendo comuns os estudos em clareiras. Götsch (1995) propõe a classificação com relação à função que a espécie exerce em cada etapa do desenvolvimento do ecossistema, sendo as espécies caracterizadas a partir da duração do ciclo de vida, altura do estrato que ocupam, padrão de ocupação, características fisionômicas e função sistêmica. Esta concepção se aproxima da defínição de "temperamento": conjunto de reações no desenvolvimento de uma árvore em relação ao seu ambiente durante seu ciclo de vida (Oldeman \& Dijk, 1991).

As espécies pioneiras foram as que apareceram em maior densidade na regeneração natural e promoveram uma transformação rápida do ambiente ao sombrear e, consequentemente, aumentar a umidade, criando condições para espécies de grupos ecológicos mais tardios se instalarem. A melhoria do micro-ambiente, principalmente por sombreamento, exerce papel significativo para o aumento de recrutamento, auxiliando a sucessão (Bazzaz, 1996). Em algumas áreas mais densamente ocupadas, o dossel formado após uma ano já alcançava aproximadamente 4 metros de altura, principalmente por Solanum granuloso-leprosum (fumo bravo), promovendo um sombreamento que naturalmente controla o crescimento desenfreado dos cipós e arbustos decumbentes (figura 14). O Croton floribundus (capixingui) e a Trema micrantha (pau pólvora) são pioneiras arbóreas que foram recrutadas em alta densidade nas 
áreas onde houve manejo. Nas capoeiras baixas há uma presença dominante de espécies pioneiras em distintas formas de vida. Duas espécies de arbustos decumbentes pioneiros ocorrem em alta densidade nas capoeiras baixas do fragmento estudado : Acacia paniculata (arranha gato) e Celtis iguanea (esporão de galo). Estas espécies dominam as áreas perturbadas, ocupando amplamente o espaço através do crescimento rápido e exercendo função de "cicatrização" dos ambientes abertos. Apresentaram alta capacidade de rebrota após a poda com reiterações nos ramos e a partir de raizes. As pioneiras, tanto herbáceas como arbóreas, compartilham muitas características como germinação de sementes, velocidade de crescimento e aspectos fisiológicos em geral (Bazzaz, 1996).

Para recuperação de áreas degradadas foi desenvolvido um método com plantio de "espécies estruturais", espécies arbóreas que promovem aceleração na sucessão natural, apresentando grande potencial para áreas onde existem remanescentes. Estas espécies exercem papéis importantes e crescem bem próximas (são gregárias), criando sombra e eliminando naturalmente as espécies invasoras (Goosem \& Tucker, 1995 apud Lamb et al., 1997). Nas parcelas experimentais foi observada a formação de "núcleos de regeneração", agregados de plântulas que estabeleceram-se próximas e criam micro-ambientes diferenciados, propiciando o estabelecimento de outras espécies.

Num levantamento fitossociológico realizado neste fragmento, foram encontradas poucas espécies pioneiras, atribuindo-se grande importância às espécies oportunistas, que podem regenerar-se sob o dossel de árvores ou de cipós (Tabanez, 1995). Espécies oportunistas podem facilmente tornar-se pioneiras antrópicas, espécies que não são pioneiras típicas, mas que podem ocupar densamente ambientes degradados (Kageyama et al., 1994). O emaranhado de cipós e arbustos decumbentes que se forma nas áreas de capoeira baixa pode ter a função de viveiro no primeiro momento, criando um ambiente de umidade e sombra propício para a germinação de espécies oportunistas, tolerantes e reprodutoras à sombra. No entanto, se não houver um manejo para o controle dos cipós, provavelmente poucas espécies poderão ter sucesso no crescimento, e os cipós, com o acúmulo de biomassa e peso, acabarão por tombar sobre as plântulas. 


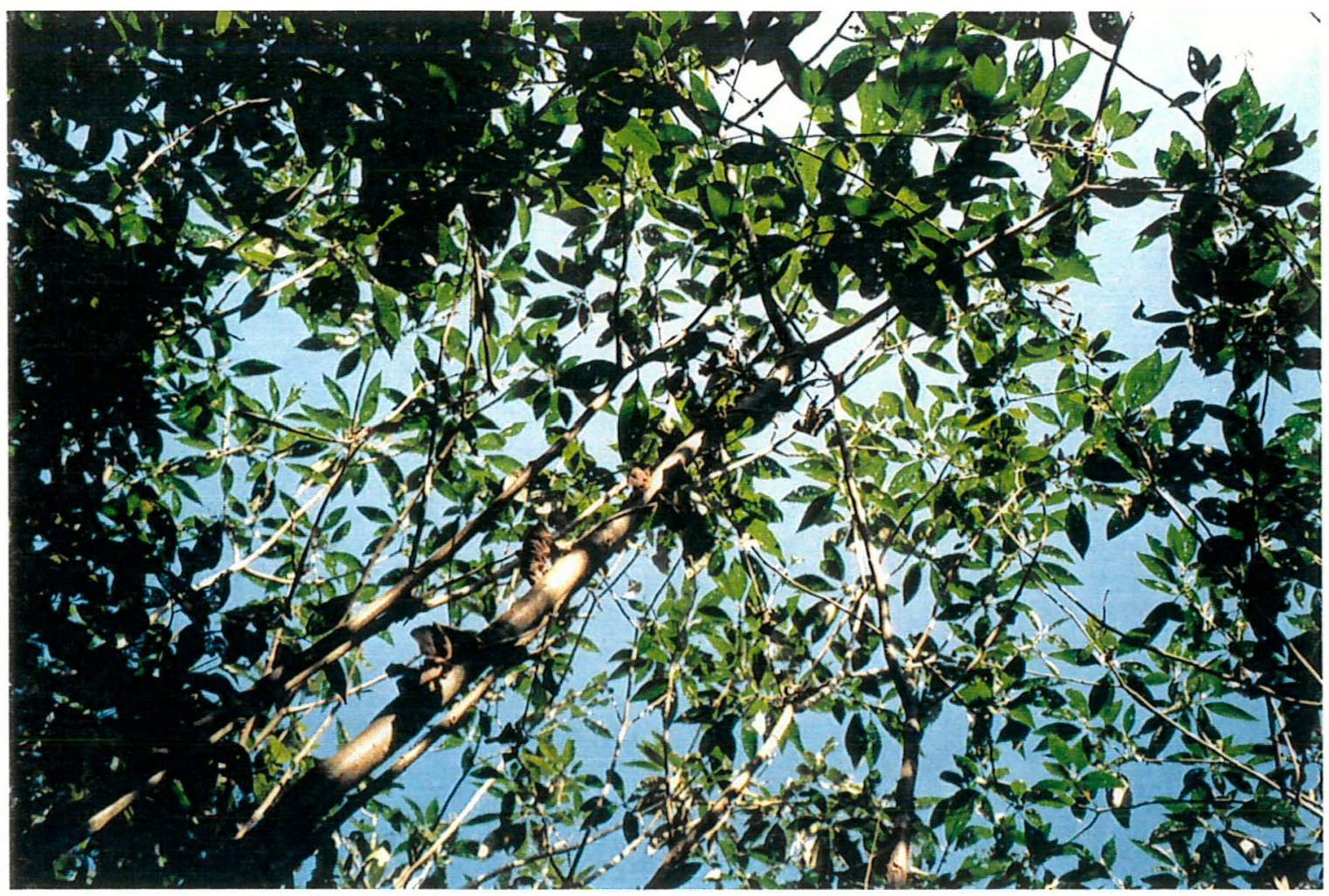

Figura 14. Dossel formado por fumo bravo (Solanum granuloso-leprosum) em área de capoeira baixa com plantio agroflorestal, um ano após a intervenção.

\subsection{2 - ESPÉCIES RECRUTAdAS POTENCIAIS PARA USO EM PROPOSTAS DE RECUPERAÇÃO}

O processo de regeneração na floresta natural através das clareiras (sucessão secundária) tem sido usado como fundamento para o plantio misto de espécies nativas visando a revegetação de matas ciliares e outras florestas de proteção (Ferreti et al., 1995). É importante o conhecimento das estratégias das plantas nativas para utilizá-las em plantios de recuperação de florestas e áreas degradadas e entender o papel que exercem na dinâmica dos fragmentos.

Dentre as espécies recrutadas, as pioneiras são as que mais chamam atenção pela plasticidade, rápido crescimento e capacidade de sombreamento. Listamos algumas espécies recrutadas, pioneiras e não-pioneiras que, por suas características, são potenciais para o uso na recuperação de áreas de capoeira baixa ou outras áreas degradadas.

- O fumo bravo (Solanum granuloso-leprosum) cresce muito rapidamente, chegando a até 5-6 metros de altura em um ano. É uma arvoreta que alcança aproximadamente 9 metros de altura, pioneira na regeneração e comum nas capoeiras em locais ensolarados (Catharino, 
1989). O ciclo de vida desta espécie é curto, produz grande quantidade de sementes, muito apreciadas por pássaros e produz muita biomassa, com folhas grandes e muitos ramos. Forma rapidamente um dossel que transforma o ambiente e promove condições mais favoráveis de sombra e umidade para o estabelecimento de espécies mais tardias, que formarão o futuro da floresta.

O capixingui (Croton floribundus) é considerado uma espécie oportunista, mas tem comportamento de pioneira em algumas situações, podendo ser considerada uma pioneira antrópica (Prof. Paulo Kageyama, comunicação pessoal). Esta espécie cresce rapidamente, alcança cerca de 15 metros de altura e pode cumprir papel fundamental para alavancar o processo de sucessão em áreas degradadas. Sua madeira é moderadamente pesada e indicada para esteios, marcenaria e obras internas; suas flores são melíferas (Lorenzi, 1992). Esta espécie ocorre em alta densidade no fragmento e teve elevada taxa de recrutamento, principalmente ao redor das árvores-mães, já que sua dispersão é autocórica. Sua frutificação coincidiu com o momento de manejo das áreas experimentais e formou um banco temporário de plântulas.

O pau pólvora (Trema micrantha) é uma espécie pioneira com grande potencial para colonização de áreas abertas. Tem crescimento rápido, sua altura fica entre 5 e 12 metros, e abre uma copa larga, promovendo grande sombreamento. É comum nas capoeiras e parece preferir solos mais férteis (Catharino, 1989). Atrai muitos pássaros, os "plantadores" naturais da floresta, e suas flores são melíferas. A madeira pode ser aproveitada para lenha, carvão, tábuas e para a fabricação de pólvora (Lorenzi, 1992).

Estas três espécies pioneiras (Solanum granuloso-leprosum, Croton floribundus e Trema micrantha) podem ser "companheiras" de espécies de grupos ecológicos mais tardios na sucessão em plantios mistos para recuperação de áreas e florestas degradadas. Podem também ser plantadas por sementes, facilmente disponíveis no fragmento ao longo do ano todo pois frutificam intensamente. As plantas pioneiras criam condições ecológicas favoráveis para a colonização de plantas com maior exigência em umidade e sombra, crescimento lento e ciclo de vida longo.

0 café (Coffea arabica) também teve alta densidade de regeneração e apresenta-se como espécie potencial para cultivo e manejo em áreas florestais, principalmente em bordas e zonas adjacentes aos fragmentos. Esta espécie é típica de sub-bosque, nativa de ambientes florestais das montanhas da Etiópia e em plantios sombreados tem apresentado bons resultados de produção (Telles Junior, 1991). Deve ter sido dispersa por pássaros a partir de 
plantios outrora existentes na região e teve boa adaptação no fragmento. $O$ café é uma bebida muito consumida, que possui propriedades estimulantes sobre os sistemas nervoso e cardíaco; é antisséptico, age no controle de febres, coqueluche, diarréia e como antídoto para a embriaguez (Rodrigues et al., 1996).

A peroba (Aspidosperma polyneuron) é uma árvore de grande porte, constitui o dossel da floresta com altura entre 20 e 30 metros, e seu ciclo de vida é longo. Sua madeira é de ótima qualidade, muito usada para construção civil e móveis pesados (Lorenzi, 1992). É uma espécie que foi intensamente explorada na região, tendo restado poucos exemplares adultos. Apresentou elevada densidade de regeneração nas capoeiras baixas manejadas. Seu crescimento é lento, devendo ser plantada preferencialmente junto à árvores de crescimento rápido.

Além das espécies arbóreas recrutadas, uma espécie arbustiva muito encontrada nas capoeiras baixas deste fragmento tem um grande potencial de manejo e aproveitamento: o "ora pro nobis" (Pereskia grandifolia), uma Cactaceae. Por serem muito ramificadas, as plantas encontradas assemelham-se a lianas, com galhos decumbentes e espinhos nos ramos, apoiandose e misturando-se às outras lianas. Suas folhas, muito tenras, são usadas em culinária e medicinalmente são usadas no tratamento contra colesterol, ou maceradas com azeite no tratamento de furúnculos (Rodrigues et al., 1996).

\section{2 - ESPÉCIES ARBÓREAS (DAP $\geq 5 \mathrm{~cm}$ ) PRESENTES NAS CAPOEIRAS BALXAS}

As espécies arbóreas com DAP $\geq 5 \mathrm{~cm}$ existentes nas capoeiras baixas experimentais pertencem a diversos grupos ecológicos e são, em grande parte, remanescentes das eco-unidades mais maduras a que pertenciam antes do processo de transformação em capoeiras baixas. Foram observadas 63 espécies pertencentes a 32 famílias (tabela 20), sendo as mais representadas : Euphorbiaceae e Rutaceae.

As árvores estão geralmente cobertas e deformadas pelo peso dos cipós e apresentam intensa reiteração lateral. Há uma alta taxa de mortalidade de árvores pelo efeito da quebra dos troncos com o peso dos cipós e os ventos. 0 efeito de borda expõe as árvores à maior intensidade de ventos, raios e insolação, e o efeito do isolamento do fragmento acarreta a falta de polinizadores e dispersores, provocando endogamia que pode levar algumas espécies à extinção local. A possibilidade de crescimento das árvores sob o domínio dos cipós é um fator de seleção 
importante em áreas vulneráveis à grande colonização por esta forma de vida, sendo uma característica a se considerar para a escolha de espécies para plantios de recuperação. Nas capoeiras baixas as árvores são muito importantes por prover sementes e promover ambientes diferenciados nas áreas, contribuindo para a formação de nichos e eco-unidades que propiciam o estabelecimento de plântulas exigentes em sombra, umidade e proteção contra o vento.

As parcelas experimentais apresentaram alta variação em relação à riqueza de espécies arbóreas (tabela 18), fato que pode ser explicado pelo histórico diferenciado das áreas e pela heterogeneidade de condições ambientais. Algumas áreas transformaram-se em capoeira baixa recentemente e ainda apresentam elevado número de árvores comparativamente com outras, que já estão como capoeira baixa há mais tempo e a maior parte das árvores está morta ou já não mais existe. A maior parte das árvores levantadas já se encontrava nas áreas antes do início da pesquisa e apenas $5,8 \%$ foram recrutadas para esta classe (DAP $\geq 5 \mathrm{~cm}$ ) após a instalação dos tratamentos (tabelas 19 e 20).

Tabela 18. Número médio, mínimo e máximo de espécies arbóreas (DAP $\geq 5 \mathrm{~cm}$ ) por parcela (de 154 a $333 \mathrm{~m}^{2}$ ) e por hectare (entre parênteses) presentes nas áreas de capoeira baixa na borda e no interior do fragmento.

\begin{tabular}{|l|l|l|l|}
\hline Parcela & Média & Mínima & Máxima \\
\hline Borda & $4,3(175)$ & $1(40,8)$ & $10(408,1)$ \\
\hline Interior & $6,26(255,5)$ & $1(40,8)$ & $14(571,4)$ \\
\hline
\end{tabular}

O padrão de similaridade florística entre as parcelas, com relação à riqueza de árvores (DAP $\geq 5 \mathrm{~cm}$ ) existentes, é maior do que para a regeneração natural $(\mathrm{h} \geq 50 \mathrm{~cm})$. Os agrupamentos observados no dendrograma (figura 15) não são os mesmos criados na regeneração natural. Para $50 \%$ no coeficiente de Jaccard foram formados três grupos com parcelas de borda e uma de interior. Ao se considerar $25 \%$ de Jaccard, outros grupos são formados e alguns refletem a proximidade espacial no fragmento que pode ser observada consultando-se a figura 8 (capítulo 2). A distribuição das populações nos fragmentos deve ser melhor compreendida em outros estudos para auxiliar o diagnóstico do estado de conservação do fragmento e o direcionamento de práticas de manejo conservacionista. 


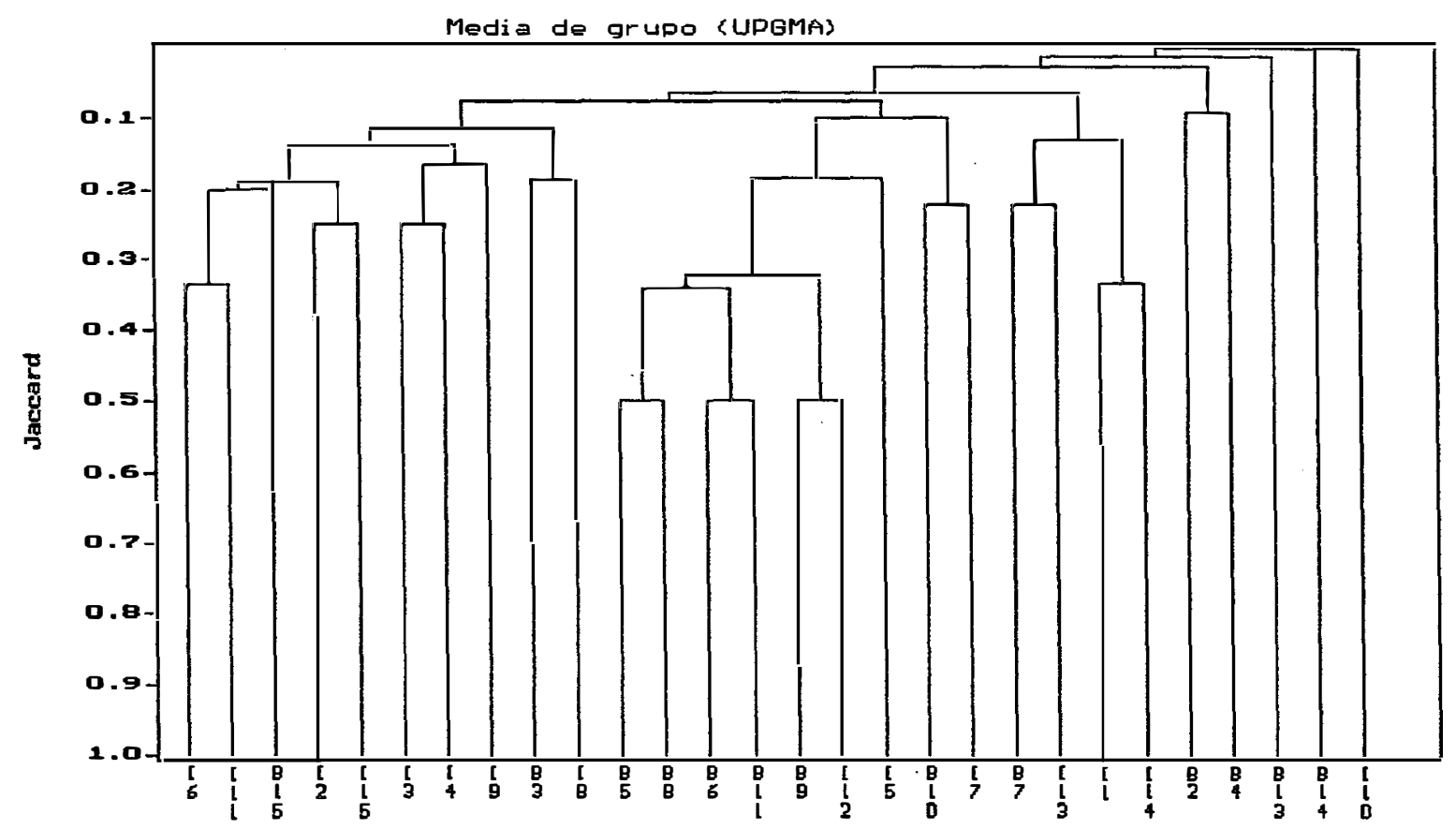

Figura 15. Dendrograma relativo às espécies arbóreas (DAP $\geq 5 \mathrm{~cm}$ ) apresentando a similaridade florística entre as parcelas, localizadas nas bordas e no interior do fragmento, sob os tratamentos: 1, poda de cipós e plantio agrícola (b3, b7, b8, b10, i2, i3, i7, i8 e i9), 2, poda de cipós e plantio agroflorestal (b2, b4, b5, b6, b9, i1, i4, i5, i6 e i10) e 3, testemunha (b11, b13, b14, b15, i1 1, i12, i13, i14 e i15).

\section{3 - A DINÂMICA DE ECO-UNIDADES NAS CAPOEIRAS BAIXAS}

Os eco-mosaicos "capoeira baixa" são similares às clareiras, apresentando características estruturais como abertura no dossel, grande incidência de luz e presença de poucas árvores. Ao manejar as capoeiras baixas com a poda dos cipós e o plantio, criou-se uma grande eco-unidade em fase inicial da sucessão. $\mathbf{O}$ processo de desenvolvimento deste ecossistema reiniciou e logo em seguida foi observado o início de um processo de fragmentação da eco-unidade, transformando a grande eco-unidade inicial criada, novamente num eco-mosaico. Pequenas ecounidades formaram-se a partir de características específicas dos sítios nas áreas. Observa-se que, além do manejo, que foi igual dentro de cada tratamento, as peculiaridades ambientais que permitem ou filtram impactos em cada parcela, são responsáveis pela fragmentação e diferenciação entre os sítios. 
Os dendrogramas relativos à regeneração e às árvores adultas ilustram bem a heterogeneidade das capoeiras baixas, que é fruto da dinâmica acelerada das eco-unidades e ecomosaicos no fragmento. $O$ alto coeficiente de variação obtido para a regeneração natural (74\%) é outro reflexo desta heterogeneidade observada dentro das capoeiras baixas e entre elas. A dinâmica das eco-unidades sugere que as intervenções humanas devam participar do processo de fragmentação natural das eco-unidades, lançando mão de práticas de manejo diferenciadas no eco-mosaico e com alta diversificação de espécies.

Os eco-mosaicos são compostos por eco-unidades em várias fases de desenvolvimento que estão em interação dinâmica. Foi avaliado que as capoeiras baixas sem intervenção são compostas por eco-unidades em fase de : (i) iniciação, em que muita biomassa é produzida e a eco-unidade está pouco estruturada e muito dinâmica, podendo ser bloqueada ou retardada pelo grande desenvolvimento de lianas ou (ii) degradação, em que a arquitetura da floresta é "quebrada", dissolvida em diversas eco-unidades menores e os organismos ficam submetidos a novas formas de "stress" (Oldeman, 1990; Rossignol et al., 1998). Existe uma zona de transição entre uma eco-unidade e outra, com um passo gradual entre as características florísticas e fisionômicas das eco-unidades que se avizinham (Prof. Roelof Oldeman, comunicação pessoal). O manejo empregado nas capoeiras baixas buscou acelerar a sucessão "desbloqueando" as ecounidades em fase de iniciação e permitindo que entrem em fase de crescimento ou agradação.

As eco-unidades são os consórcios naturais em que as plantas ocorrem na natureza. As espécies têm ciclo de vida e altura variáveis e exercem distintas funções nos ecossistemas. A dinâmica das eco-unidades pode ser compreendida também através da sucessão de consórcios (figura 16). Cada consórcio representa uma fase do sistema e prepara o ambiente para o próximo consórcio. Os sistemas colonizadores são os criadores de condições de vida, criam as primeiras redes e a tarefa principal é a transformação da matéria orgânica. Os sistemas de ótima ocupação caracterizam-se pela alta acumulação de carbono em sistemas de vida, com ampla relação $\mathrm{C} / \mathrm{N}$ e processos lentos de transformação de matéria orgânica. Os sistemas de abundância são de altíssima complexidade, com redes mais sensíveis a perturbações; os processos de transformação são rápidos e freqüentes, devido principalmente à estreita relação entre carbono e nitrogênio (Penereiro, 1999). 


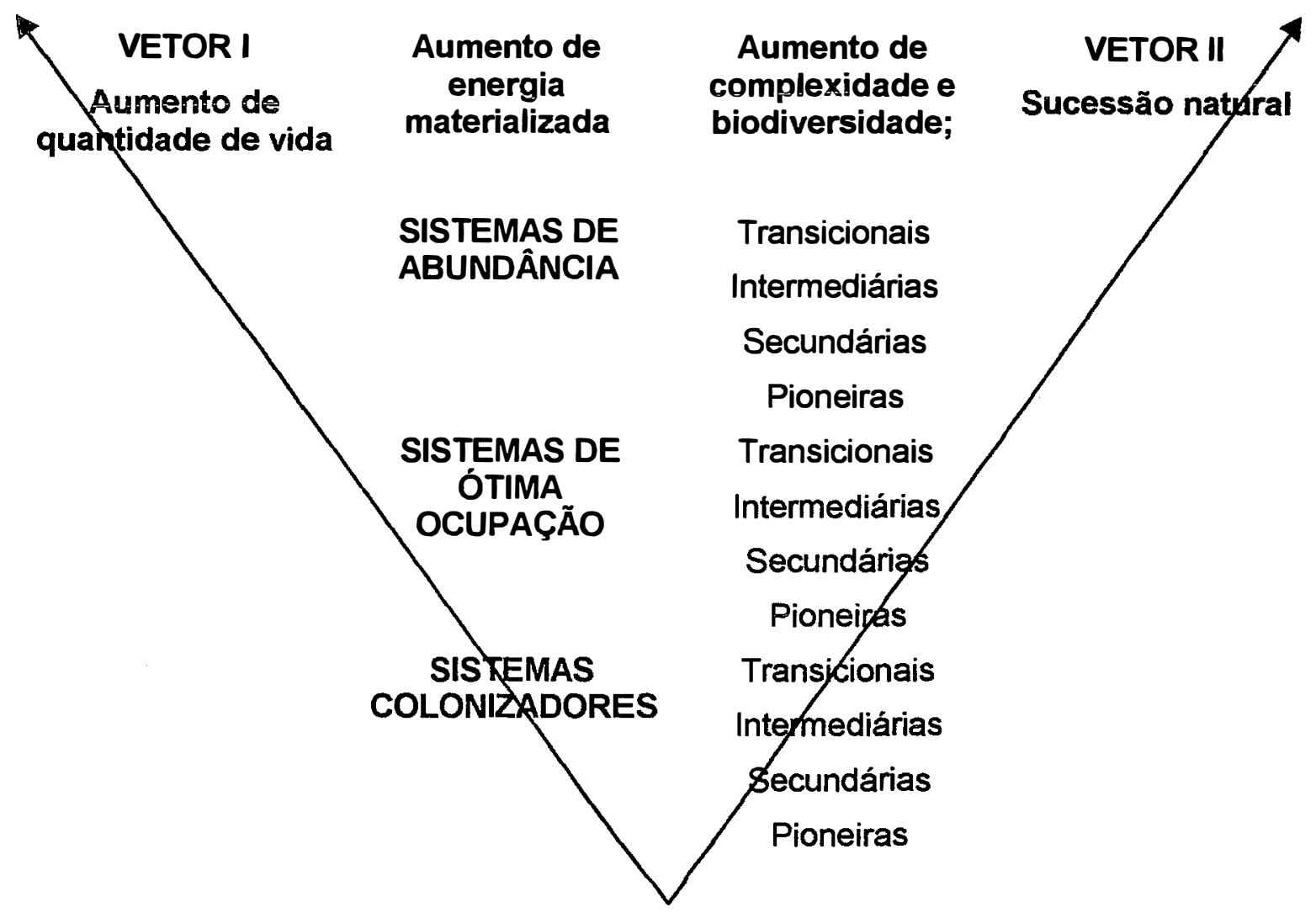

Figura 16. Gráfico vetorial de vida com os sistemas e os grupos ecológicos de espécies representando a sucessão natural e o aumento de quantidade de vida. (Adaptado de Göstch em Penereiro, 1999).

Uma interpretação para a situação encontrada neste trabalho é que as áreas de capoeira baixa são "sistemas de ótima ocupação" e os consórcios criados pelas plântulas recrutadas substituíram os cipós e arbustos decumbentes pioneiros com estratégia de ocupação do espaço. $\mathbf{O}$ objetivo do manejo foi criar condições para os consórcios arbóreos deste sistema se estabelecerem, preparando todo o eco-mosaico para o "sistema de abundância", que caracteriza as florestas tropicais.

Os sistemas agroflorestais análogos aos ecossistemas naturais necessitam informações acerca dos processos sucessionais locais, além do conhecimento sobre as espécies nativas, seus locais de origem, ciclo de vida, altura e microsítios que ocupam. Os consórcios são plantados juntos, a partir da condição inicial do sistema de origem, e acompanham os vetores de aumento de quantidade de vida e sucessão natural. As intervenções almejam a complexificação e as estratégias de recuperação representam a facilitação deste processo. 


\section{CONCLUSÕES}

Os tratamentos com manejo compreendendo poda de cipós e plantio agrícola ou agroflorestal revelaram-se aceleradores da sucessão, possibilitando que espécies arbóreas que não conseguiam ter seu recrutamento efetivado por impedimento físico e biológico pudessem colonizar as áreas. Assim como a densidade de plântulas recrutadas (h $\geq 50 \mathrm{~cm})$ em um ano foi maior nas áreas que incluíram manejo (tabela 19), a riqueza de espécies também foi maior nas parcelas com os tratamentos 1 (591 espécies/ha nas bordas e 573 no interior) e 2 (500 espécies/ha nas bordas e 636,3 no interior) do que nas testemunhas (136,3 espécies/ha nas bordas e 254,5 no interior). Estes resultados indicam que os tratamentos incluindo poda de cipós e plantio contribuem para a facilitação da sucessão natural através da indução da regeneração natural. As espécies recrutadas nas áreas experimentais representam diversos grupos ecológicos. As espécies mais recrutadas foram as pioneiras Solanum granuloso-leprosum e Croton floribundus, que assim como outras, são potenciais em plantios para recuperação de áreas degradadas. Pela rapidez de crescimento, criam em pouco tempo condições ambientais bem diferentes das iniciais, principalmente através do sombreamento. Não foi observada similaridade floristica entre as parcelas nem para as árvores (DAP $\geq 5 \mathrm{~cm}$ ) nem para a regeneração natural (h $\geq 50 \mathrm{~cm}$ ), refletindo a grande heterogeneidade das capoeiras baixas após o manejo aplicado. A dinâmica observada através da acelerada fragmentação das eco-unidades em eco-mosaicos contribui para a alta heterogeneidade observada dentro das parcelas e entre elas. 
Tabela 19. Dados médios dos parâmetros considerados para a avaliação da dinâmica das capoeiras baixas com os tratamentos 1 , poda de cipós e plantio agrícola, 2, poda dos cipós e plantio agroflorestal e 3 , testemunha. Os resultados englobam as parcelas de borda e interior.

\begin{tabular}{|l|l|l|l|}
\hline \multicolumn{1}{|c|}{ PARÂMETROS } & $\begin{array}{l}\text { TRATAMENTO 1 } \\
\text { PLANTIO } \\
\text { AGRÍCOLA }\end{array}$ & $\begin{array}{c}\text { TRATAMENTO 2 } \\
\text { PLANTIO } \\
\text { AGROFLORESTAL }\end{array}$ & $\begin{array}{l}\text { TRATAMENTO 3 } \\
\text { TESTEMUNHA }\end{array}$ \\
\hline $\begin{array}{l}\text { Densidade de plântulas } \\
\text { no primeiro mês } \\
\text { (ind/ha) }\end{array}$ & 450 & 460 & 533 \\
\hline $\begin{array}{l}\text { Densidade de plântulas } \\
\text { após um ano (ind/ha) }\end{array}$ & 2.233 & 2.091 & 580 \\
\hline $\begin{array}{l}\text { Recrutamento de } \\
\text { plântulas (ind/ha) }\end{array}$ & 1.783 & 1.631 & 47 \\
\hline $\begin{array}{l}\text { Densidade de plantio } \\
\text { de árvores (ind/ha) }\end{array}$ & - & 1.666 & - \\
\hline $\begin{array}{l}\text { Sobrevivência das } \\
\text { árores plantadas (\%) }\end{array}$ & - & 85 & - \\
\hline $\begin{array}{l}\text { Número de espécies } \\
\text { arbóreas recrutadas } \\
\text { ( } \geq 50 \text { cm) por hectare }\end{array}$ & 581,8 & 568 & 195,4 \\
\hline $\begin{array}{l}\text { Densidade de árvores } \\
\text { pré-existentes (ind/ha) } \\
\text { (DAP } \geq 5 \mathrm{~cm} \text { ) }\end{array}$ & 398,8 & 464,8 & 222,72 \\
\hline $\begin{array}{l}\text { Densidade de árvores } \\
\text { (ind/ha) após um ano } \\
\text { (DAP } \geq 5 \mathrm{~cm} \text { ) }\end{array}$ & 408,2 & 468 & 205 \\
\hline $\begin{array}{l}\text { Area basal inicial } \\
\text { (mª) } / \text { ha) }\end{array}$ & 3,45 & 4,74 & 3,45 \\
\hline $\begin{array}{l}\text { Area basal após um ano } \\
\text { (m²/ha) }\end{array}$ & 3,75 & 5,62 & \\
\hline
\end{tabular}


Tabela 20. Espécies presentes nas parcelas experimentais nas condições:

$A$ : regeneração natural $(\mathrm{h} \geq 50 \mathrm{~cm})$ em 1 mês;

B : regeneração natural $(\mathrm{h} \geq 50 \mathrm{~cm})$ em 1 ano;

C : árvore (DAP $\geq 5 \mathrm{~cm}$ ) pré-existente;

D : árvore (DAP $\geq 5 \mathrm{~cm})$ presente em 1 ano;

E : muda plantada.

\begin{tabular}{|c|c|c|c|c|c|c|c|}
\hline Família & Espécie & $\begin{array}{c}\text { Nome } \\
\text { popular }\end{array}$ & $\mathbf{A}$ & $\mathbf{B}$ & $\mathbf{C}$ & $\mathbf{D}$ & $\mathbf{E}$ \\
\hline Anacardiaceae & Astronium graveolens Jaca. & guaritá & $\mathbf{x}$ & $\mathbf{x}$ & $\mathbf{x}$ & $\mathbf{x}$ & \\
\hline Anacardiaceae & Schinus terebenthifolius Raddi & $\begin{array}{l}\text { aroeira } \\
\text { pimenteira }\end{array}$ & & & & & $\mathrm{x}$ \\
\hline Annonaceae & Duguetia lanceolata A.St.-Hil. & pindaíva & $\mathbf{x}$ & $\mathbf{x}$ & & & \\
\hline Annonaceae & Rollinia sylvatica (A.St.-Hil.)Mart. & $\begin{array}{l}\text { araticum do } \\
\text { mato }\end{array}$ & & & & & \\
\hline Apocynaceae & $\begin{array}{l}\text { Aspidosperma polyneuron Müell. } \\
\text { Arg. }\end{array}$ & peroba & $\mathbf{x}$ & $\mathbf{x}$ & $\mathbf{x}$ & $\mathbf{x}$ & \\
\hline Apocynaceae & $\begin{array}{l}\text { Aspidosperma ramiflorum Müell. } \\
\text { Arg. }\end{array}$ & guatambu & & & $\mathbf{x}$ & $\mathbf{x}$ & \\
\hline Areacaceae & $\begin{array}{l}\text { Syagrus romanzoffiana (Cham.) } \\
\text { Glassm. }\end{array}$ & jjerivá & & $\mathbf{x}$ & $\mathbf{x}$ & $\mathbf{x}$ & \\
\hline Asteraceae & Vernonia diffusa Less. & & & $\mathbf{x}$ & & & \\
\hline Asteraceae & Vernonia polyanthes (Spreng.)Less. & lassa peixe & & $\mathbf{x}$ & & & \\
\hline Asteraceae & Vernonia sp. & & $\mathbf{x}$ & $\mathbf{x}$ & & & \\
\hline Bignoniaceae & Jacaranda micrantha Cham. & carobão & & & $\mathbf{x}$ & $\mathbf{x}$ & \\
\hline Bignoniaceae & Tabebuia sp. & & & & $\mathbf{x}$ & $\mathbf{x}$ & \\
\hline Bignoniaceae & Zeyheria tuberculosa (Vell.) Bur. & ipê felpudo & & & $\mathbf{x}$ & $\mathbf{x}$ & $\mathbf{x}$ \\
\hline Bombacaceae & Chorisia speciosa St. Hil. & paineira & & & $\mathbf{x}$ & $\mathbf{x}$ & \\
\hline Bombacaceae & Eriotheca sp. & & & & & $\mathbf{x}$ & \\
\hline Boraginaceae & Cordia ecalyculata Vell. & |café de bugre & & & $\mathbf{x}$ & $\mathbf{x}$ & \\
\hline Boraginaceae & Cordia sellowiana Cham. & $\begin{array}{l}\text { capitão do } \\
\text { campo }\end{array}$ & & $\mathbf{x}$ & & & \\
\hline Boraginaceae & Patagonula americana L. & guaịuvira & $\mathbf{x}$ & $\mathbf{x}$ & & & \\
\hline Caesalpinaceae & Bauhinia forficata Link & Ipata de vaca & $\mathbf{x}$ & $\mathrm{x}$ & $\mathbf{x}$ & $\mathrm{x}$ & \\
\hline Caesalpinaceae & Holocalyx balansae Mich. & $\begin{array}{l}\text { alecrim de } \\
\text { campinas }\end{array}$ & $\mathbf{x}$ & $\mathbf{x}$ & $\mathbf{x}$ & $\mathbf{x}$ & \\
\hline Caesalpinaceae & Hymenaea courbaril $\mathrm{L}$. & liatobá & & & $\mathrm{x}$ & $\mathrm{x}$ & \\
\hline Caesalpinaceae & $\begin{array}{l}\text { Peltophorum dubium } \\
\text { (Spreng.)Taub. }\end{array}$ & canafistula & & $\mathrm{x}$ & & & $\bar{x}$ \\
\hline Caesalpinaceae & Schizolobium parahyba (Vell.) & guapuruvu & & & & & $x$ \\
\hline Caricaceae & |Jacaratia spinosa (Aubl.) A. DC. & ljaracatiá & & $\mathbf{x}$ & $\mathbf{x}$ & $\mathbf{x}$ & \\
\hline Cecropiaceae & Cecropia pachystachya Trécul & embaúba & & $\mathrm{x}$ & $\mathbf{x}$ & $\mathbf{x}$ & \\
\hline Celastraceae & Maytenus robusta Reiss. & cafezinho & & & & & \\
\hline Elaeocarpaceae & Sloanea monosperma Vell. & |carrapicheiro & $\mathbf{x}$ & $\mathbf{x}$ & $\mathbf{x}$ & $\mathbf{x}$ & \\
\hline Euphorbiaceae & $\begin{array}{l}\text { Alchornea triplinervea (Spreng.) M } \\
\text { Arg. }\end{array}$ & tapiá & & $\mathrm{x}$ & $\mathrm{x}$ & $\mathbf{x}$ & \\
\hline Euphorbiaceae & Savia dyctiocarpa Kuhlm. & guaraiuva & & $\mathbf{x}$ & $\mathrm{x}$ & $\mathbf{x}$ & \\
\hline
\end{tabular}




\begin{tabular}{|c|c|c|c|c|c|c|c|}
\hline Euphorbiaceae & Sebastiania serrata Müll.Arg. & branquilho & & & & & \\
\hline Euphorbiaceae & $\begin{array}{l}\text { Actinostemon concolor } \\
\text { (Spreng.)Müll.Arg. }\end{array}$ & & & & & & \\
\hline Euphorbiaceae & $\begin{array}{l}\text { Actinostemon klotzschii } \\
\text { (Müll.Arg.)Pax. }\end{array}$ & branquilho & $x$ & $\mathbf{x}$ & & & \\
\hline Euphorbiaceae & Alchornea glandulosa Poepp. & tapiá & & $\mathbf{x}$ & & & \\
\hline Euphorbiaceae & Croton floribundus (L.)Spreng. & capixingui & $\mathbf{x}$ & $\mathrm{x}$ & $\mathrm{x}$ & $\mathbf{x}$ & \\
\hline Euphorbiaceae & Croton priscus Croizat & pau sangue & & & & & \\
\hline Euphorbiaceae & Sebastiania sp. & & $\mathrm{x}$ & $\mathrm{x}$ & & & \\
\hline Euphorbiaceae & $\begin{array}{l}\text { Sebastiania klotzschiana } \\
\text { (Müll.Arg.) }\end{array}$ & branquilho & & & $\mathrm{x}$ & $\mathrm{x}$ & \\
\hline Fabaceae & \begin{tabular}{|l|} 
Centrolobium tomentosum Guill. Ex \\
Benth.
\end{tabular} & araribá & & & $\mathbf{x}$ & $\mathbf{x}$ & \\
\hline Fabaceae & Lonchocarpus sp. & $\begin{array}{l}\text { embira de } \\
\text { sapo }\end{array}$ & & & $\mathrm{x}$ & $\mathrm{x}$ & \\
\hline Fabaceae & $\begin{array}{l}\text { Machaerium nyctitans (Vell.) } \\
\text { Benth. }\end{array}$ & $\begin{array}{l}\text { jacarandá } \\
\text { ferro }\end{array}$ & & & $\mathrm{x}$ & $\mathrm{x}$ & \\
\hline Fabaceae & Machaerium stipitatum (DC.) Vog. & |sapuvinha & $\mathrm{x}$ & $\mathbf{x}$ & $\mathbf{x}$ & $\mathbf{x}$ & \\
\hline Fabaceae & Machaerium brasiliensis Vogel & ఏjacarandá & & $\mathbf{x}$ & & & \\
\hline Fabaceae & Rhynchosia phaseoloides (SW.)DC. & & & $\mathrm{x}$ & & & \\
\hline Fabaceae & Zollernia ilicifolia (Brongn.)Vogel & & $\mathbf{x}$ & $\mathbf{x}$ & & & \\
\hline Flacourtiaceae & Casearia gossypiosperma Briquet & pau espeto & & & $\mathbf{x}$ & $\mathbf{x}$ & \\
\hline Flacourtiaceae & Casearia sylvestris $\mathrm{Sw}$. & guaçatonga & & $\mathbf{x}$ & $\mathrm{x}$ & $\mathbf{x}$ & \\
\hline Icacinaceae & $\begin{array}{l}\text { Citronella paniculata (Mart.) } \\
\text { Howard }\end{array}$ & citronela & & & $\mathrm{x}$ & $\mathbf{x}$ & \\
\hline Lauraceae & Cryptocarya moschata Nees & \begin{tabular}{|l|l|} 
canela \\
batalha
\end{tabular} & & & $\mathrm{x}$ & $\mathrm{x}$ & \\
\hline Lauraceae & Ocotea cf. beulahiae Baitello & |canela & & & $\mathrm{x}$ & $\mathbf{x}$ & \\
\hline Lauraceae & Ocotea pulchella (Nees.) Mez & $\begin{array}{l}\text { canela } \\
\text { lageana }\end{array}$ & & & $\mathrm{x}$ & $\mathrm{x}$ & \\
\hline Lauraceae & Ocotea sp. & & & & $\mathbf{x}$ & $\mathrm{x}$ & \\
\hline Lauraceae & $\begin{array}{l}\text { Endlicheria paniculata } \\
\text { (Spreng.)J.F.Macbr. }\end{array}$ & $\begin{array}{l}\text { canela do } \\
\text { brejo }\end{array}$ & $\mathbf{x}$ & $\mathrm{x}$ & & & \\
\hline Lauraceae & $\begin{array}{l}\text { Nectandra megapotamica } \\
\text { (Spreng.)Mez }\end{array}$ & canelinha & & $\mathrm{x}$ & & & \\
\hline Lecythidaceae & Cariniana legalis (Mart.) O. Kuntze & jequitibá & & & $\mathrm{x}$ & $\mathrm{x}$ & $\mathrm{x}$ \\
\hline Meliaceae & Cedrela fissilis Vell. & cedro & & & $\mathrm{x}$ & $\mathbf{x}$ & \\
\hline Meliaceae & Trichilha elegans A.Juss. & $\begin{array}{l}\text { catiguá de } \\
\text { folha miúda }\end{array}$ & & $\mathbf{x}$ & & & \\
\hline Meliaceae & Trichilha pallida SW. & $\begin{array}{l}\text { catiguá } \\
\text { amarelo }\end{array}$ & $\mathrm{x}$ & $\mathbf{x}$ & $\mathrm{x}$ & $\mathbf{x}$ & \\
\hline Mimosaceae & Acacia glomerosa Benth. & 1 & & $\mathrm{x}$ & & & \\
\hline Mimosaceae & Acacia polyphylla DC. & Imonjoleiro & & & $\mathrm{x}$ & $\mathbf{x}$ & \\
\hline Mimosaceae & Acaciasp. & 1 & & & $\mathbf{x}$ & $\mathrm{x}$ & \\
\hline Mimosaceae & Inga sp. & |ingá & $\mathbf{x}$ & $\mathbf{x}$ & $\mathbf{x}$ & $\mathbf{x}$ & \\
\hline Mimosaceae & $\begin{array}{l}\text { Piptadenia gonoacantha (Mart.) } \\
\text { Macbr. }\end{array}$ & pau jacaré & $x$ & $x$ & $x$ & $x$ & \\
\hline
\end{tabular}




\begin{tabular}{|c|c|c|c|c|c|c|}
\hline Mimosaceae & \begin{tabular}{|l} 
Enterolobium contortisiliqum \\
(Vell.)Morong
\end{tabular} & tamboril & & & $\mathrm{x}$ & $\mathrm{x}$ \\
\hline Moraceae & Ficus guaranitica Chodat & figueira & & $\mathbf{x}$ & & \\
\hline Moraceae & $\begin{array}{l}\text { Sorocea bonplandii } \\
\text { (Baill.)W.C.Burger }\end{array}$ & cincho & & & & \\
\hline Myrtaceae & Eugenia florida DC & guamirim & & & $\mathbf{x}$ & $\mathbf{x}$ \\
\hline Myrtaceae & Campomanesia xanthocarpa & sete capotes & & $\mathbf{x}$ & & \\
\hline Myrtaceae & Eugenia uniflora L. & pitanga & & $\mathbf{x}$ & & \\
\hline Nyctaginaceae & Guapira opposita (Vell.)Reitz & maria mole & & $\mathbf{x}$ & $\mathrm{x}$ & $\mathbf{x}$ \\
\hline Opiliaceae & Agonandra englerii Hoehne & & & & $\mathbf{x}$ & $\mathbf{x}$ \\
\hline Phytolacaceae & Seguieria floribunda Benth & limão bravo & & & & \\
\hline Piperaceae & Piper sp. & & & $\mathbf{x}$ & & \\
\hline Proteaceae & Roupala brasiliensis Klotz. & came de vaca & & & $\mathbf{x}$ & $\mathbf{x}$ \\
\hline Rhamnaceae & Rhamnidium elaeocarpus Reiss. & $\begin{array}{l}\text { saguaraji } \\
\text { amarelo }\end{array}$ & & & $\mathbf{x}$ & $\mathrm{x}$ \\
\hline Rubiaceae & Amaioua guianensis Subl. & $\begin{array}{l}\text { marmelada } \\
\text { brava }\end{array}$ & & & $\mathrm{x}$ & $\bar{x}$ \\
\hline Rubiaceae & Coffea arabica L. & café & $\mathbf{x}$ & $\mathrm{x}$ & & \\
\hline Rubiaceae & Psychotria deflexa DC. & & & $\mathbf{x}$ & & \\
\hline Rubiaceae & $\begin{array}{l}\text { Psychotria hoffmannseggiana } \\
\text { (Willd. Ex Roem.\& Schult.) Mü }\end{array}$ & & & $\mathbf{x}$ & & \\
\hline Rubiaceae & $\begin{array}{l}\text { Psychotria leiocarpa Cham. \& } \\
\text { Schltdl. }\end{array}$ & & $\mathbf{x}$ & $\mathbf{x}$ & & \\
\hline Rubiaceae & Psychotria sp. 2 & & & $\mathbf{x}$ & & \\
\hline Rubiaceae & Psychotria sp. 3 & & $\mathbf{x}$ & $\mathrm{x}$ & & \\
\hline Rubiaceae & Psychotria sp. 4 & & & $\mathrm{x}$ & & \\
\hline Rubiaceae & Psychotria sp.1 & & & $\mathbf{x}$ & & \\
\hline Rubiaceae & Randia armata (SW.)DC. & & $\mathbf{x}$ & $\mathbf{x}$ & & \\
\hline Rutaceae & $\begin{array}{l}\text { Almeideia coerulea (Nees \& } \\
\text { Mart.)A.St.-Hil. }\end{array}$ & & $\mathbf{x}$ & $\mathbf{x}$ & $\mathbf{x}$ & $\mathbf{x}$ \\
\hline Rutaceae & $\begin{array}{l}\text { Balfourodendron riedelianum } \\
\text { (Engl.) }\end{array}$ & pau marfim & & & $\mathbf{x}$ & $\mathbf{x}$ \\
\hline Rutaceae & Esenbeckia febrifuga A.Juss. & mamoninha & $\mathbf{x}$ & $\mathbf{x}$ & $\mathbf{x}$ & $\mathbf{x}$ \\
\hline Rutaceae & Esenbeckia grandiflora Mart. & guaxupita & & $\mathbf{x}$ & $\mathrm{x}$ & $\mathrm{x}$ \\
\hline Rutaceae & Esenbeckia leiocarpa Engl. & guarantã & & & $\mathbf{x}$ & $\mathbf{x}$ \\
\hline Rutaceae & Galipea multiflora Schlecht. & quina quina & $\mathbf{x}$ & $\mathbf{x}$ & $\mathbf{x}$ & $\mathrm{x}$ \\
\hline Rutaceae & Metrodorea nigra A.St.-Hil. & chupa ferro & $\mathbf{x}$ & $\mathbf{x}$ & $\mathbf{x}$ & $\mathbf{x}$ \\
\hline Rutaceae & Zanthoxylum riedelianum Engl. & $\begin{array}{l}\text { mamica de } \\
\text { porca }\end{array}$ & & $\mathrm{x}$ & $\mathbf{x}$ & $\mathrm{x}$ \\
\hline Sapindaceae & Dianopteryx sorbifolia Radlk. & Imaria preta & $\mathbf{x}$ & $\mathbf{x}$ & $\mathrm{x}$ & $\mathrm{x}$ \\
\hline Sapindaceae & Matayba elaeagnoides Radlk. & camboatá & $\mathrm{x}$ & $\mathrm{x}$ & $\mathbf{x}$ & $\mathbf{x}$ \\
\hline Sapindaceae & Allophyllus edulis (St.-Hil.)Radlk & |fruta de faraó & $\mathbf{x}$ & $\mathrm{x}$ & & \\
\hline Sapindaceae & Cupania vernalis Camb. & gragoatã & $\mathbf{x}$ & $\mathbf{x}$ & & \\
\hline Sapotaceae & $\begin{array}{l}\text { Chrysophyllum gonocarpum } \\
\text { (Mart. \& Eichl.) Engl. }\end{array}$ & $\begin{array}{l}\text { guatambu de } \\
\text { leite. }\end{array}$ & $\mathbf{x}$ & $\mathrm{x}$ & $\mathbf{x}$ & $\mathbf{x}$ \\
\hline
\end{tabular}




\begin{tabular}{|c|c|c|c|c|c|c|c|}
\hline Solanaceae & Cestrum laevigatum Schltdl. & & $\mathbf{x}$ & $\mathbf{x}$ & & $\mathbf{x}$ & \\
\hline Solanaceae & Solanum sp. & & $\mathbf{x}$ & $\mathbf{x}$ & & & \\
\hline Solanaceae & $\begin{array}{l}\text { Solanum swartzianum Roem. \& } \\
\text { Schult. }\end{array}$ & & & & $\mathbf{x}$ & $\bar{x}$ & \\
\hline Solanaceae & Solanum aculeatissimum Jacq. & & & & & & \\
\hline Solanaceae & Solanum argenteum Dunal & folha de prata & $\mathbf{x}$ & $\mathbf{x}$ & & & \\
\hline Solanaceae & $\begin{array}{l}\text { Solanum granuloso-leprosum } \\
\text { Dunal }\end{array}$ & fumo bravo & $\mathbf{x}$ & $\mathbf{x}$ & & $\mathbf{x}$ & \\
\hline Solanaceae & Solanum megalochiton Mart. & & & $\mathbf{x}$ & & & \\
\hline Solanaceae & Solanum pseudoquina A.St.-Hil. & lioá de árvore & & $\mathbf{x}$ & & & \\
\hline Solanaceae & Solanum sp. & & & & & & \\
\hline Sterculiaceae & Guazuma ulmifolia Lam. & Imutambo & & & & & $\mathbf{x}$ \\
\hline Ulmaceae & Trema micrantha (L.) Blum. & pau pólvora & & $\mathbf{x}$ & $\mathbf{x}$ & $\mathbf{x}$ & \\
\hline Ulmaceae & Celtis iguanae (Jacq.)Sarg. & $\begin{array}{l}\text { esporão de } \\
\text { galo }\end{array}$ & $\mathbf{x}$ & $\mathbf{x}$ & $\mathbf{x}$ & $\mathbf{x}$ & \\
\hline Urticaceae & Urera baccifera $(\mathrm{L}$.$) Gaudich$ & |urtigão & $\mathbf{x}$ & $\mathbf{x}$ & $\mathbf{x}$ & $\mathbf{x}$ & \\
\hline Verbenaceae & Aegiphila sellowiana Cham & tamanqueira & $\mathbf{x}$ & $\mathbf{x}$ & $\mathbf{x}$ & $\mathbf{x}$ & \\
\hline Verbenaceae & Lantana camara $\mathrm{L}$. & cambará & $\mathbf{x}$ & $\mathbf{x}$ & & & \\
\hline Verbenaceae & Lippia sp. & & $\mathbf{x}$ & $\mathbf{x}$ & & & \\
\hline Verbenaceae & Cytharexylum myrianthum Cham. & pau viola & & & & & $\mathrm{x}$ \\
\hline Violaceae & $\begin{array}{l}\text { Hybanthus atropurpureus } \\
\text { (A.St.-Hil.)Taub. }\end{array}$ & & $\mathbf{x}$ & $\mathbf{x}$ & & & \\
\hline
\end{tabular}




\section{CAPÍtulo IV \\ RELAÇÃO E PERCEPÇÃO DE PESSOAS E INSTITUIÇÕES COM O FRAGMENTO CAPUAVA}

"Estar na Floresta é ter a natureza do Homem junto da natureza de Deus" D. Maria de Fátima

\section{INTRODUÇÃO}

A conservação da natureza é sempre uma questão cultural, apesar das ações conservacionistas se darem como se a preservação da natureza não tivesse nada a ver com a espécie humana (Posey, 1988). O ambiente reflete os caminhos sociais do meio envolvente a partir das interações, ações e relações do universo humano com o natural. É preciso compreender o cenário natural junto às inter-relações com os atores sociais para então buscar alternativas de conservação e recuperação ambiental concretas, possíveis e compatíveis com o contexto sóciocultural local. A ecologia quer enfatizar o enlace existente entre todos os seres naturais e culturais e sublinhar a rede de interdependências vigentes de tudo com tudo, constituindo a totalidade ecológica, em que tudo que existe, coexiste e se relaciona (Boff, 1993).

As relações entre a fragmentação florestal e os fatores sócio-econômicos e culturais precisam ser abordadas de forma interdisciplinar para melhor entendimento de suas conseqüências sobre a conservação da biodiversidade e para buscar estratégias alternativas capazes de mitigar os efeitos negativos. Na região do planalto ocidental paulista, a maior parte da cobertura florestal (74\%) está em propriedades privadas. Por isso, metodologias inovadoras devem ser criadas para desenvolver as estratégias de conservação nessa região (Viana, 1995). Os fragmentos, mesmo localizados em propriedades privadas, são freqüentemente visitados por moradores da região com diversos objetivos. Grupos religiosos, que têm lugares sagrados na floresta e lá fazem seus rituais, 
caçadores que vão à caça de animais silvestres e pessoas que procuram a floresta em busca de paz, ar puro e silêncio, são alguns dos freqüentadores dos fragmentos ainda existentes. Assim, faz-se necessário desenvolver trabalhos em nível local com as pessoas relacionadas com o fragmento, para envolvê-las nas estratégias de recuperação e conservação. A restauração ecológica deve estar aliada à restauração bio-cultural, trazendo a biologia de volta ao repertório cultural, junto à música, a religião e as artes (Janzen, 1986). Esta abordagem pode ser a base da elaboração de planos de recuperação de fragmentos, com educação ambiental e criação de políticas públicas envolvendo a questão.

A análise de grupos de interesse (“stakeholders analysis") é um método e procedimento para se obter o entendimento de um sistema ao identificar os atores-chave ou os participantes do sistema e acessar seus respectivos interesses. Por "grupos de interesse" (“stakeholders"), entendese todos aqueles grupos que afetam e/ou são afetados por políticas, ações e decisões no sistema, podendo ser indivíduos, grupos sociais, comunidades ou instituições (Grimble \& Chuan, 1995). Este tipo de análise vem sendo utilizado para auxiliar planos de manejo florestal sustentável, especificando ações com relação a diferentes grupos que promovem impactos ou são afetados pela floresta. Os vários grupos de interesse têm distintas relações e diferentes responsabilidades e direitos sobre a floresta (Colfer, 1995) e, desta forma, são agentes no processo de conservação e recuperação. Além desta análise, o resgate etnoecológico pode enriquecer a compreensão do sistema pelo conhecimento local, a partir da percepção e relação das pessoas com seu meio. A etnoecologia é o estudo da interação das pessoas com o meio natural e aponta para uma visão holística do conhecimento sobre o ambiente (Martin, 1995).

A maior parte das terras do interior do Estado de São Paulo vem sendo ocupada intensamente por agricultura desde o século passado, período de rápida expansão da fronteira agrícola, inicialmente com a cultura do café. Atualmente, a principal produção agrícola da região é a cana-de-açúcar e grande parte dos pequenos fragmentos florestais espalhados encontra-se dentro de fazendas de produção de cana, freqüentemente localizados em terrenos impróprios para a agricultura. A produção da cana-de-açúcar utiliza mão-de-obra intensamente na época da colheita durante um período do ano, disponibilizando os trabalhadores no outro período, por aproximadamente seis meses. A colheita da cana se faz nos meses mais secos (de maio a novembro) e, na época chuvosa (novembro a abril), propícia para plantios em geral, grande parte dos trabalhadores fica desempregada. Esta mão-de-obra poderia trabalhar em projetos de 
recuperação ambiental no período de entressafra, conciliando a resolução de um problema social com a recuperação ambiental. Desta forma, é necessário um entendimento da dinâmica de trabalho, do grau de envolvimento e conhecimento da floresta pelos trabalhadores e o desenvolvimento de tecnologias de recuperação florestal que a viabilizem economicamente.

A valorização da floresta a partir de suas mais diversas funções, serviços e produtos pode ser o início para uma ampla conscientização quanto à sua importância. A perspectiva econômica é uma consideração fundamental para agricultores e proprietários, pois para eles a terra é fator de produção e geração de renda. Como agravante, a agricultura encontra-se em crise atualmente, com baixo valor de mercado para os produtos agrícolas e alto custo dos insumos, impossibilitando investimentos em recuperação ambiental nas propriedades. A conservação e recuperação dos fragmentos florestais deve ser economicamente viável, apresentando baixo custo e/ou um retomo de capital que compense este custo em curto prazo. A legislação, que prevê áreas de reserva legal (os fragmentos florestais) em $20 \%$ da propriedade, além das áreas de preservação permanente, é um instrumento para a conservação, mas não vem sendo cumprida por falta de conscientização, fomento, políticas públicas, acompanhamento técnico, fiscalização e alternativas economicamente viáveis para implantação e conservação destas áreas.

Este trabalho visa identificar as instituições, grupos e pessoas direta ou indiretamente relacionadas com o fragmento florestal da fazenda Capuava para estabelecer ligações e entender os níveis de influência exercidos pelos distintos atores sociais. A partir desta identificação, pretende-se abordar os padrões de relação e percepção das pessoas com o fragmento, entendendo os aspectos culturais e políticos envolvidos, e contribuir para o direcionamento de linhas de trabalho com educação e participação das pessoas na recuperação e conservação dos fragmentos.

\section{MATERIAL E MÉTODOS}

Os métodos utilizados foram definidos ao longo do processo da pesquisa, junto com o conhecimento do Universo social e as primeiras intervenções. Ocorreu desta forma em função do envolvimento dos atores sociais participantes da pesquisa e a partir da avaliação da repercussão das metodologias propostas. Em ciências sociais, a metodologia é considerada como o estudo do método, e muitas vezes o método se constrói ao longo do processo do trabalho (Becker, 1994). 


\section{1 - COMUNIDADE DA FAZENDA CAPUAVA}

Inicialmente, fez-se o primeiro contato com as pessoas da comunidade de moradores da fazenda Capuava. Foram feitas visitas e entrevistas informais ou através de roteiro semiestruturado a alguns moradores da comunidade de trabalhadores da fazenda e vizinhos. Também foram propostas dinâmicas lúdicas, reuniões e atividades de educação ambiental com as crianças na escola da comunidade. As técnicas utilizadas nesta pesquisa foram: (i) entrevistas semiestruturadas, em que tópicos de questões são previamente elaborados e outras questões são inseridas ao longo da entrevista, (ii) matriz de critérios e opções, dinâmica em que elementos são escolhidos (ex. espécies florestais) e, a partir de critérios pré-definidos em grupo, são avaliados, (iii) perfil histórico, geralmente feito com moradores antigos, visando o resgate de fatos históricos importantes na região, (iv) mapeamento da propriedade, consistindo em um mapa dinâmico e informativo que auxilia a identificação, localização e interação entre elementos da paisagem, e (v) atividades de educação ambiental na escola da vila de moradores da Capuava, onde estudam crianças de 7 a 12 anos, de $1^{\mathrm{a}}$ a $4^{\mathrm{a}}$ série.

As entrevistas aos moradores da comunidade, feitas a partir de roteiro semi-estruturado, foram registradas com anotações e gravações. $\mathrm{O}$ roteiro básico das entrevistas foi :

i) Caracterização sócio-econômica : nome, profissão, número de moradores na casa, local de origem da família, tempo de residência na fazenda Capuava e função do trabalhador na fazenda.

ii) Relação com o fragmento :

- Importância

- Freqüência de visitas

- Usos - diretos e indiretos

- Histórico do fragmento

- Avaliação do estado de conservação do fragmento

- Recomendações de práticas de manejo para o fragmento

iii) Espécies plantadas nos quintais das casas

Foram atribuidos valores às respostas quanto à relação com o fragmento, para se tirar uma média e definir uma tendência neste aspecto. Algumas respostas estão expressas com o pensamento, lógica e idéias das pessoas. 


\section{2 - PROPRIETÁRIO DA FAZENDA CAPUAVA}

O proprietário da fazenda Capuava, Sr. Caio Matthiessen Gudmon, é parceiro do Laboratório de Silvicultura Tropical (ESALQ/USP) desde 1993, quando começaram as pesquisas no fragmento da fazenda. No início deste trabalho, em 1996, foi exposto o objetivo da pesquisa e fez-se uma primeira entrevista informal. Dois anos depois, foi feita outra entrevista e alguns resultados preliminares da pesquisa foram expostos.

\section{3 - GRUPOS RELIGIOSOS}

A partir de entrevistas com os moradores da comunidade e vestígios encontrados no fragmento, soube-se que grupos religiosos freqüentam a floresta para seus rituais. Por serem grupos que se relacionam diretamente com a floresta, representando uma forma de relação diferenciada e inédita na região, buscou-se conhecer e entrevistar alguns integrantes das Igrejas que fazem estes rituais. Para entender os motivos que os levam a realizar seus cultos na floresta e compreender esta forma de relação espiritual com a floresta, alguns religiosos foram entrevistados informalmente.

\section{4 - INSTITUIÇÕES RELACIONADAS AO FRAGMENTO CAPUAVA}

As instituições relacionadas à questão florestal em Piracicaba foram identificadas e contactadas a partir de seus representantes. Um primeiro contato foi feito no "Workshop sobre Recuperação de Fragmentos Florestais", realizado em junho de 1996, promovido pela Prefeitura Municipal de Piracicaba (Secretaria Municipal de Defesa do Meio Ambiente) e pela ESALQ (Departamento de Ciências Florestais). Em novembro de 1997, foi realizado no fragmento Capuava um "workshop" de campo para exposição das pesquisas em andamento, avaliação conjunta dos resultados preliminares e um levantamento de possibilidades para a continuidade do manejo. Foram convidados representantes de instituições ligadas à questão ambiental no município e pesquisadores e estudantes da ESALQ/USP. Numa segunda etapa, realizaram-se entrevistas individuais com os representantes das instituições abordando questões relativas à atuação da entidade perante a problemática dos fragmentos na região e as propostas e formas de contribuição (pessoais e institucionais) para um plano de recuperação. 
O roteiro das entrevistas foi semi-estruturado e englobou os seguintes aspectos:

- Linha de atuação da instituição

- Atividades relacionadas à questão dos fragmentos exercidas pela instituição

- Estratégias que julga importantes para a recuperação florestal

- Proposta de políticas públicas para a questão dos fragmentos e do desmatamento

- Principais problemas ambientais na região

- Conhecimento do fragmento Capuava

- Sugestões para recuperar o fragmento Capuava

- Propostas e formas de contribuição para recuperação de fragmentos florestais na região (pessoal e institucional)

As respostas às entrevistas estão apresentadas na íntegra e foram agrupadas por tópico abordado, permitindo que as idéias e a lógica das pessoas aparecessem expressas de forma completa, não perdendo a autenticidade.

\section{RESULTADOS E DISCUSSÃO}

Os grupos, pessoas e instituições relacionados com o fragmento florestal da fazenda Capuava foram identificados e entrevistados para uma análise dos usos, atividades e ações que envolvem direta e indiretamente o fragmento. Os grupos e pessoas envolvidas são: o proprietário, a comunidade de moradores e trabalhadores da fazenda Capuava, os caçadores, os grupos religiosos, a SEDEMA (Secretaria Municipal de Defesa do meio Ambiente da Prefeitura Municipal de Piracicaba), a SEMA (Secretaria Municipal de Agricultura), o SEMAE (Serviço Municipal de Água e Esgoto de Piracicaba), o DEPRN (Departamento Estadual de Proteção dos Recursos Naturais), a ESALQ (Escola Superior de Agricultura Luis de Queiroz), e a organização não-governamental IMAFLORA (Instituto de Manejo e Certificação Florestal e Agrícola) (figura 17). 


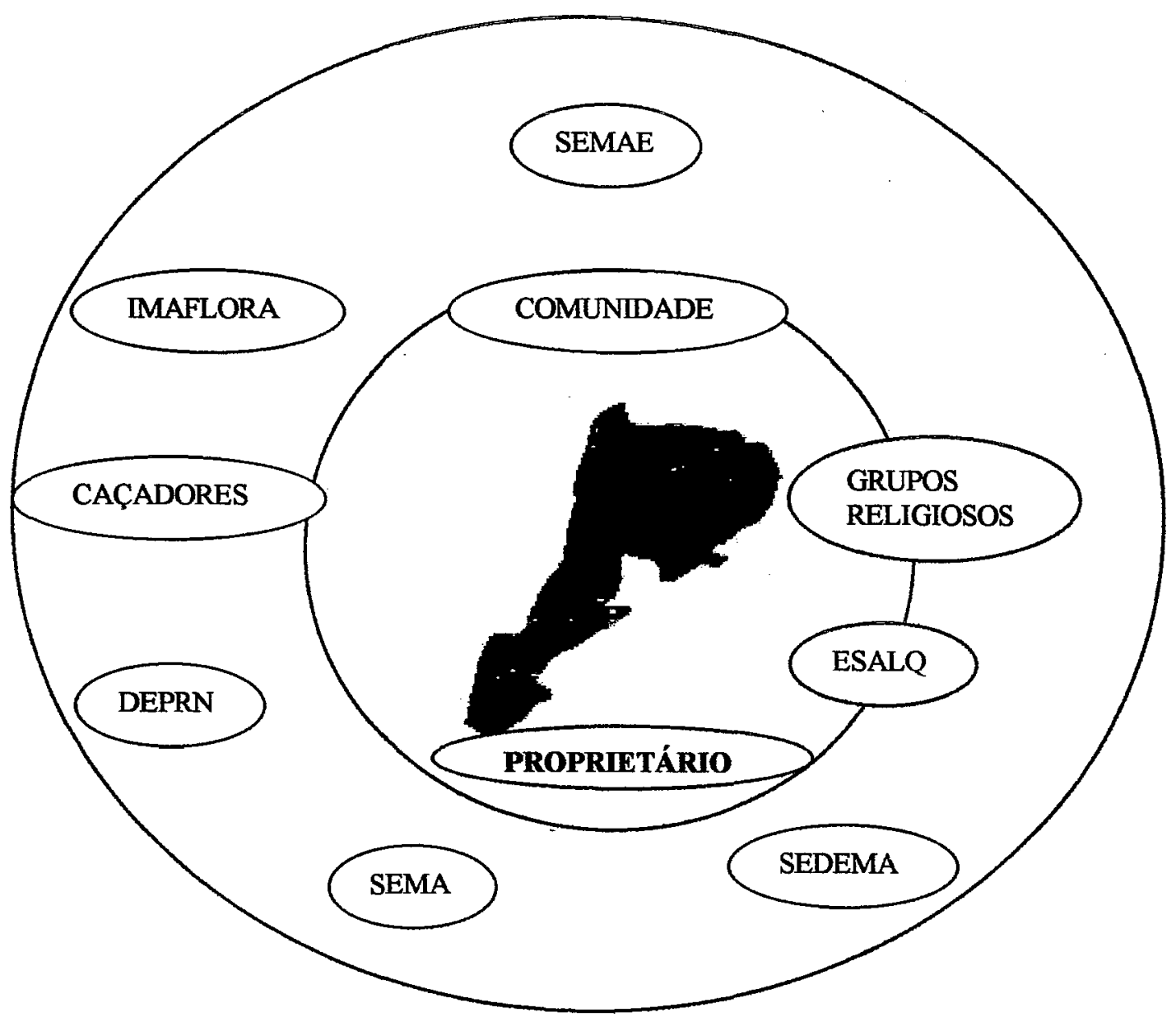

Figura 17. Órbita de relações das pessoas e instituições com o fragmento florestal da fazenda Capuava. A distância em relação ao fragmento representa o nível direto ou indireto da relação.

\section{1 - COMUNIDADE DE MORADORES DA FAZENDA CAPUAVA}

Para a elaboração e planejamento do projeto de pesquisa de recuperação de áreas de capoeira baixa do fragmento florestal Capuava, buscou-se o envolvimento e participação da comunidade de moradores da fazenda. Para o planejamento do experimento foi feito um levantamento das espécies florestais e agrícolas mais conhecidas e/ou utilizadas na região e o conhecimento histórico da fazenda e do fragmento. Optou-se por uma pesquisa-ação envolvendo a comunidade de moradores com o intuito de aproximá-la dos trabalhos de pesquisa em curso e localizar o trabalho dentro do contexto sócio-cultural local. Na primeira fase foi apresentado o "Projeto Fragmentos" desenvolvido pelo Laboratório de Silvicultura Tropical (ESALQ/USP), as pesquisas desenvolvidas no fragmento Capuava e os resultados até agora obtidos em outras 
pesquisas. A proposta inicial foi reunir o grupo e estimular uma participação efetiva no processo prático de instalação das áreas experimentais. Como a comunidade não tem o hábito de reuniões e não dispõe de tempo para o trabalho no campo, esta primeira idéia foi reformulada e buscou-se uma participação a nível de idéias e discussões acerca da questão da recuperação do fragmento.

Inicialmente houve o conhecimento e aproximação com a comunidade. Duas reuniões foram organizadas e realizadas na fazenda. $\mathrm{Na}$ primeira reunião, foi feito um levantamento de espécies potenciais para o plantio na recuperação das áreas de capoeira baixa experimentais. Montou-se uma matriz de critérios e opções para a escolha de espécies a partir de funções e características eleitas pelos participantes (tabela 21). Foram citadas espécies que ocorriam na região e já não mais ocorrem, as que estão em vias de extinção e plantas úteis de forma geral com utilidades diversas : medicinais, alimento para fauna, madeira, etc. Foi realizada também uma discussão acerca da recuperação do fragmento com a participação de 18 moradores da comunidade da fazenda Capuava e arredores e a esposa do proprietário da fazenda. A segunda reunião teve a presença majoritária de crianças, em que foram desenvolvidas atividades de educação ambiental e mostra de slides com imagens do fragmento e das áreas em recuperação.

$\mathrm{Na}$ escola da fazenda foram desenvolvidas atividades com o intuito de promover uma extensão do trabalho em andamento, reaproximar as crianças da floresta e entender a relação que têm com o fragmento e o ambiente de forma geral. Foi feito um plantio de mudas, brincadeiras educativas e uma excursão com as crianças ao fragmento, ocasião em que a maioria delas visitou pela primeira vez a floresta.

Para entrevistar os moradores da comunidade da fazenda Capuava foram visitadas todas as 50 casas das três colônias. Porém, em algumas delas os moradores não foram encontrados. Das 50 casas, 30 foram entrevistadas, totalizando uma amostra de $60 \%$ do Universo. As entrevistas foram feitas com as pessoas presentes na casa no momento da visita que se deu em horários sem expediente de trabalho, principalmente em finais de semana. Os dados levantados com a comunidade residente na fazenda Capuava e arredores refletem o envolvimento de algumas pessoas com o fragmento e a preocupação com aspectos ambientais globais, como a poluição do ar e da água, "venenos"(agrotóxicos) lançados por avião contaminando o ar e o solo, e a extinção de espécies, principalmente animais. 
Tabela 21. Matriz de critérios para escolha de espécies agrícolas e arbóreas, elaborada pela comunidade de moradores da fazenda Capuava.

\begin{tabular}{|c|c|c|c|c|c|c|c|}
\hline Espécies & $\begin{array}{l}\text { Benefício } \\
\text { para o } \\
\text { Homem }\end{array}$ & $\begin{array}{l}\text { Beneficio } \\
\text { para } \\
\text { animais }\end{array}$ & Porte & $\begin{array}{l}\text { Cresci- } \\
\text { Mento }\end{array}$ & \begin{tabular}{|l|} 
Tempo \\
de vida
\end{tabular} & $\begin{array}{l}\text { Hábito } \\
\text { (luz) }\end{array}$ & $\begin{array}{l}\text { Relação } \\
\text { com cipós }\end{array}$ \\
\hline $\begin{array}{l}\text { paineira } \\
\text { Chorisia } \\
\text { speciosa }\end{array}$ & Algodão & $\begin{array}{l}\text { Fruto para } \\
\text { Periquito }\end{array}$ & Grande & Devagar & Longo & $\overline{\text { Sol }}$ & Escapa \\
\hline $\begin{array}{l}\text { jerivá } \\
\text { Syagrus } \\
\text { romanzoffiana }\end{array}$ & Fruto & $\begin{array}{l}\text { Fruto para } \\
\text { gato do } \\
\text { mato, } \\
\text { serelepe, } \\
\text { macaco } \\
\end{array}$ & Grande & Médio & Longo & Sombra & Escapa \\
\hline $\begin{array}{l}\text { jatobá } \\
\text { Hymenaea } \\
\text { courbaril } \\
\end{array}$ & $\begin{array}{l}\text { Fruto, } \\
\text { Remédio e } \\
\text { Xarope }\end{array}$ & $\begin{array}{l}\text { Fruto para } \\
\text { macaco, } \\
\text { pássaros }\end{array}$ & Grande & Devagar & Longo & $\begin{array}{l}\text { Sol e } \\
\text { sombra }\end{array}$ & Não escapa \\
\hline $\begin{array}{l}\text { coqueiro } \\
\text { Cocos nucifera }\end{array}$ & $\begin{array}{l}\text { Água e } \\
\text { Fruto }\end{array}$ & Fruto & Grande & Devagar & Longo & Sol & Escapa \\
\hline $\begin{array}{l}\text { ipề } \\
\text { Tabebuia sp. }\end{array}$ & $\begin{array}{l}\text { Madeira e } \\
\text { Flor }\end{array}$ & $\begin{array}{l}\text { Flor para } \\
\text { vários } \\
\text { animais } \\
\end{array}$ & Média & Médio & Longo & Sol & Não escapa \\
\hline $\begin{array}{l}\text { manga } \\
\text { Mangifera } \\
\text { indica }\end{array}$ & Fruta & \begin{tabular}{|l|} 
Fruta para \\
vários \\
animais \\
\end{tabular} & Grande & Rápido & Médio & Sol & Escapa \\
\hline $\begin{array}{l}\text { jabuticaba } \\
\text { Myrciaria } \\
\text { trunciflora }\end{array}$ & Fruta & $\begin{array}{l}\text { Fruta para } \\
\text { animais }\end{array}$ & Média & Devagar & Longo & Sombra & Não escapa \\
\hline $\begin{array}{l}\text { goiaba } \\
\text { Psidium } \\
\text { guajava } \\
\end{array}$ & Fruta & Fruta & Média & Devagar & Média & Sol & Não escapa \\
\hline $\begin{array}{l}\text { pitanga } \\
\text { Eugenia } \\
\text { uniflora }\end{array}$ & Fruta & Fruta & Média & Devagar & Longo & Sol & Escapa \\
\hline $\begin{array}{l}\text { laranja } \\
\text { Citrus sp. }\end{array}$ & Fruta & Fruta & Média & Rápido & Curto & Sol & Não escapa \\
\hline $\begin{array}{l}\text { maracujá } \\
\text { Passiflora } \\
\text { edulis }\end{array}$ & Fruta & Fruto & Médio & Rápido & Curto & Sol & $\begin{array}{l}\text { Escapa } \\
\text { (é cipó) }\end{array}$ \\
\hline $\begin{array}{l}\text { abóbora } \\
\text { Cucurbita sp. }\end{array}$ & Boa & Boa & \begin{tabular}{|l} 
Peque- \\
na
\end{tabular} & Rápido & Curto & Sol & $\begin{array}{l}\text { Escapa } \\
\text { (é cipó) }\end{array}$ \\
\hline $\begin{array}{l}\text { milho } \\
\text { Zea mays }\end{array}$ & Bom & Bom & \begin{tabular}{|l}
$\begin{array}{l}\text { Peque- } \\
\text { no }\end{array}$ \\
\end{tabular} & Rápido & Curto & Sol & Não escapa \\
\hline
\end{tabular}

Nota : Esta tabela foi elaborada pelos moradores da comunidade da fazenda Capuava. A relação com cipós foi discutida quanto à possibilidade da espécie ser dominada ou não pelos cipós durante o crescimento ("escape ou não escape”). 
As respostas obtidas nas entrevistas revelaram alguns padrões de percepção e relação dos moradores da comunidade com o fragmento. No processo de aproximação e conhecimento das pessoas da comunidade foram identificadas algumas com maior afinidade com a floresta e com grande conhecimento dos processos ecológicos e históricos ocorridos ali. $\mathrm{O}$ perfil histórico e o mapeamento da propriedade foram feitos com um senhor que reside num sítio vizinho à fazenda Capuava há 58 anos. À medida que desenhava o mapa, contou algumas histórias da fazenda e levantou acontecimentos marcantes ocorridos na região como a mudança do plantio da cultura de café para a cana-de-açúcar, a exploração madeireira realizada no fragmento, a mudança do clima, que hoje é mais seco e quente do que antigamente, e citou diversas espécies animais e vegetais que ali existiam e hoje já não mais se encontram. Este senhor conhece muitos pássaros e citou alguns que já não mais se encontram na região : curió, azulão, nambu guaçú, perdiz, nambuzinho, codominha, saracura, cigarrinha, acapí, batuíra, foguinho, bilro, entre outros que estão desaparecendo, segundo ele, por causa do veneno utilizado na cultura da cana.

Algumas citações ilustram a preocupação e o envolvimento dos moradores com o ambiente:

- Devastaram tudo. Guarantã não tem mais por aí, só na Capuava.

- Com 13 anos de idade, passava o dia na mata caçando : veado, paca, tatu, capivara. Hoje já não tem mais nada. Esta floresta era maior.

- Para recuperar não adianta plantar estas árvores bobas, tem que plantar ipê, jequitibá, peroba, crandiúva, estas madeiras boas.

- O governo tinha que fazer alguma coisa com estas usinas que jogam veneno de avião

- O veneno tinha que acabar; os usineiros só pensam nisso (dinheiro). Com agrotóxico o grilo fica envenenado, o passarinho come e morre. Os bichos ajudam a acabar com as pragas.

- O ar está envenenado; vai na Santa Casa o povo tá todo doente.

- O pessoal prende os passarinhos. Devia deixar solto. Se bem que hoje se deixar eles livres, eles se envenenam. É muito veneno! O veneno vem e mata as plantas, penetra na terra, nas nascentes e rios.

- Os macacos estão comendo os ovos dos passarinhos. Devia plantar frutas para tratar deles.

- Sem a mata ocorre desequilibrio ambiental no clima. Pode ser mata, mata cerrada, fechada, pomar; sempre traz fruto prá nós e para os animais

- Uma árvore sozinha não dá frutos; tem que ter par delas para a abelha ir lá e cruzar 
- Eu gostaria é de morar no Xingu. Aquilo é que é vida!

- Não larguem a mata não! Alguém tem que continuar a trabalhar lá.

Foram atribuídos valores às respostas das entrevistas e a média exprime o perfil da comunidade em sua relação com o fragmento (tabela 22).

\section{Tópicos abordados e valores atribuídos:}

1- Importância do fragmento : 0- não é importante; 1- pouco importante; 2- muito importante

2-Histórico do fragmento : 0- não conhece; 1- não mudou; 2- mudou pouco; 3- mudou muito

3- Usos do fragmento : 0- nenhum; 1- algum uso; 2- faz uso

4- Frequência de visita : 0 - nunca foi; 1 -já foi; 2 - vai ás vezes

5- Avaliação do estado do fragmento : 0- não tem; 1- está bom; 2- está ruim

Tabela 22. Valores atribuídos às respostas nas entrevistas realizadas na comunidade da Capuava.

\begin{tabular}{|c|c|c|c|c|c|}
\hline ENTREVISTADO & IIMPORTÃNCIA & HISTÓRICO & USO & |FREQUÊNCIA & IAVALIAÇÃO \\
\hline 1 & 2 & 0 & 0 & 0 & 1 \\
\hline 2 & 2 & 1 & 0 & 0 & 1 \\
\hline 3 & 1 & 1 & 0 & 2 & 1 \\
\hline 4 & 2 & 2 & 0 & 1 & 2 \\
\hline 5 & 2 & 2 & 1 & 2 & 2 \\
\hline 6 & 1 & 1 & 0 & 1 & 1 \\
\hline 7 & 1 & 1 & 0 & 0 & 1 \\
\hline 8 & 0 & 0 & 0 & 0 & 0 \\
\hline 9 & 2 & 1 & 1 & 2 & 1 \\
\hline 10 & 2 & 1 & 1 & 2 & . 1 \\
\hline 11 & 1 & 1 & 0 & 1 & 1 \\
\hline 12 & 1 & 0 & 0 & 2 & 0 \\
\hline 13 & 1 & 1 & 1 & 2 & 1 \\
\hline 14 & 2 & 1 & 1 & 1 & 1 \\
\hline 15 & 2 & 2 & 0 & 2 & 2 \\
\hline 16 & 1 & 0 & 0 & 0 & 0 \\
\hline 17 & 1 & 0 & 0 & 2 & 1 \\
\hline 18 & 2 & 2 & 1 & 2 & 2 \\
\hline 19 & 1 & 1 & 1 & 2 & 0 \\
\hline 20 & 2 & 2 & 0 & 2 & 1 \\
\hline 21 & 2 & 1 & 0 & 2 & 1 \\
\hline 22 & 2 & 1 & 0 & 2 & 2 \\
\hline 23 & 2 & 2 & 0 & 2 & 1 \\
\hline 24 & 2 & 2 & 1 & 2 & 1 \\
\hline 25 & 2 & 1 & 0 & 0 & 1 \\
\hline 26 & 2 & 2 & 0 & 1 & 1 \\
\hline 27 & 2 & 2 & 0 & 1 & 2 \\
\hline 28 & 1 & 0 & 0 & 1 & 2 \\
\hline 29 & 2 & 0 & 0 & 2 & 1 \\
\hline MÉDIA & 1,5 & 1 & $\mathbf{0 , 3}$ & 1,3 & 1 \\
\hline
\end{tabular}


A média dos valores atribuidos às respostas aponta que na opinião destas pessoas : (i) a floresta é importante para a maioria das pessoas, tendo de pouca a muita importância, (ii) a floresta não mudou ultimamente, (iii) as pessoas praticamente não fazem uso de nenhum produto da floresta, (iv) não visitam o fragmento com freqüência, mas a maioria já visitou pelo menos uma vez, e (v) a floresta está em bom estado de conservação. Estas respostas, aliadas a comportamentos não-verbais e comentários durante as entrevistas, exprimem que não existe uma relação direta da maioria dos moradores da comunidade com o fragmento. No entanto, acham importante conservá-lo, principalmente pela qualidade do ar. Quase ninguém conhece as espécies florestais e seus potenciais, mas alguns demonstram interesse em conhecer mais. A avaliação da situação do fragmento para a maioria é de que deve-se deixar o fragmento como está, não precisando de recuperação. Alguns recomendam o plantio de mais árvores, flores, frutas, além de outras práticas e demonstram percepções em algumas palavras (tabela 23).

Tabela 23 - Citações de alguns membros da comunidade de moradores da Fazenda Capuava durante as entrevistas.

\begin{tabular}{|c|c|c|c|}
\hline \begin{tabular}{|l|} 
MOTIVO DA IMPORTÂNCIA \\
DO FRAGMENTO
\end{tabular} & \begin{tabular}{|l|} 
HISTÓRICO \\
DA FLORESTA \\
\end{tabular} & USOS & \begin{tabular}{|l|} 
AVALIAÇÃO E \\
RECOMENDAÇÕES \\
\end{tabular} \\
\hline \multicolumn{4}{|l|}{ Ar puro, macacos } \\
\hline \multicolumn{4}{|l|}{ Ar puro } \\
\hline $\begin{array}{l}\text { Ar puro, animais, alegria, chama } \\
\text { poluição }\end{array}$ & Mata está velha & Oração & Muito cipó, árvores velhas \\
\hline Lugar de moradia para bichos & & Orquidea & $\begin{array}{l}\text { Dificil de andar, muito cipó, pouca } \\
\text { madeira boa }\end{array}$ \\
\hline Para os passarinhos & & & $\begin{array}{l}\text { Mata pequena, antes desmatavam, hoje } \\
\text { não mais }\end{array}$ \\
\hline Para respirar & & $\begin{array}{l}\text { Orquídea, } \\
\text { passeio, } \\
\text { pesca }\end{array}$ & \\
\hline É gostosa & & \begin{tabular}{|lr} 
Ver & bichos, \\
flores, & pescar \\
\end{tabular} & \\
\hline \multicolumn{4}{|l|}{ Árvores bonitas } \\
\hline Ar puro & & Pesca & \\
\hline Ar fresco, traz chuva & & $\begin{array}{l}\text { Guaçatonga } \\
\text { (remédio) }\end{array}$ & \\
\hline Ar puro, presença dos bichos & Chuva diminuiu & & Cipó sufoca as árvores \\
\hline \multicolumn{4}{|l|}{ Ar, beleza } \\
\hline Traz chuva e saúde, muito valor! & $\begin{array}{l}\text { Mata foi } \\
\text { acabando }\end{array}$ & Orquídea & O tempo dos arboridos era bom... \\
\hline Lugar verde bonito & & Orquídea & \\
\hline Oxigênio & Aumento do cipó & Não pode & Cuidar do cipó, muito trabalho \\
\hline
\end{tabular}




\begin{tabular}{|c|c|c|c|}
\hline \begin{tabular}{|l|} 
MOTIVO DA IMPORTÂNCIA \\
DO FRAGMENTO
\end{tabular} & \begin{tabular}{|l|} 
HISTÓRICO \\
DA FLORESTA \\
\end{tabular} & USOS & \begin{tabular}{|l|} 
AVALIAÇÃO E \\
RECOMENDAÇOES \\
\end{tabular} \\
\hline "Se acabar a mata nós morre" & & & Tem que plantar mais na mata \\
\hline Dá oxigênio e tira o CO2 & & & Plantar fruta para os bichos \\
\hline $\begin{array}{l}\text { Manter equilibrio do clima, traz } \\
\text { frutos para nós }\end{array}$ & \multicolumn{2}{|c|}{$\begin{array}{l}\text { Mudou, eu ajudei a plantar as } \\
\text { mudas }\end{array}$} & Plantar frutíferas para os bichos \\
\hline Saúde & Aumentou & |Vou orar & Plantar mais árvore com abóbora \\
\hline \multicolumn{2}{|l|}{ Bonita, tem muitas espécies de plantas } & & Plantar flores em volta para embelezar \\
\hline \multicolumn{3}{|l|}{ Preservação dos animais } & \\
\hline Ar puro e animais & $\begin{array}{l}\text { Aumentou } \\
\text { tamanho }\end{array}$ & & $\begin{array}{l}\text { Cortar mato em volta, tirar árvores } \\
\text { secas }\end{array}$ \\
\hline Prefere a paisagem limpa & & \begin{tabular}{|l|} 
Não conhece \\
pra que serve \\
as plantas
\end{tabular} & $\begin{array}{l}\text { A mata tá feia, desorganizada, plantar } \\
\text { flores e árvores mais bonitas }\end{array}$ \\
\hline Enfeita a fazenda, & & $\left|\begin{array}{lr}\text { Não } & \text { pode } \\
\text { tirar árvore }\end{array}\right|$ & $\begin{array}{l}\text { Arrancar os cipós que es } \\
\text { árvores }\end{array}$ \\
\hline
\end{tabular}

\section{2 - PROPRIETÁRIO DA FAZENDA CAPUAVA}

O proprietário da Fazenda Capuava é herdeiro desta propriedade, que pertence à familia há cerca de 110 anos. A produção principal da fazenda é de cana-de-açúcar para a fabricação de cachaça para exportação em usina própria e produção de CO2. A fazenda produz também girassol em áreas de rotação de cultura e possui uma área com plantio de eucalipto. A "Capuava Agropecuária S.A." tem quarenta funcionários permanentes, sendo que na safra da cana são contratados trabalhadores temporários.

O fragmento florestal da fazenda Capuava é, para o proprietário, uma área de preservação. Nesta reserva ele pretende manter os remanescentes de flora e fauna para conservação da natureza. Ele diz que quer que seus netos vejam a natureza, portanto tem uma valorização sentimental que o move a preservar o fragmento. Tem vontade de plantar um corredor de floresta ligando este fragmento a outro próximo e revegetar as áreas ciliares na propriedade. Sempre foi muito aberto aos projetos de pesquisa desenvolvidos pelo Laboratório de Silvicultura Tropical -ESALQ/USP desenvolvidos lá desde 1993, tomando-se um parceiro das atividades de pesquisa.

Sua preocupação com o fragmento é grande e sempre foi avesso aos caçadores que lá vão caçar. Ultimamente, quando soube a respeito dos grupos religiosos que fazem seus cultos na floresta, fechou os acessos ao fragmento para impedir que estes grupos entrassem lá. Esta medida foi tomada em janeiro de 1998, após ser informado sobre a quantidade de lixo deixada por estas 
pessoas, velas utilizadas nos rituais, representando risco de incêndio na floresta, e do grande número de carros que entrava semanalmente na fazenda. Segundo nota de ocorrência, os seguranças que foram retirar o grupo do local disseram que as pessoas estavam em transe, gritando e abraçadas umas às outras. A solicitação para deixarem o local foi expressa da seguinte forma : "Esta é uma propriedade particular cuja mata é de preservação permanente, e portanto protegida por lei, sendo o proprietário fiel responsável pela mesma". Após este episódio, houve um encontro de nossa equipe com o proprietário em que foram discutidos possíveis mecanismos normatizadores para a entrada e uso da floresta.

\section{3 - GRUPOS RELIGIOSOS}

Foram identificados cinco grupos religiosos que fazem seus cultos e rituais em diversos pontos do fragmento Capuava. As entrevistas com os religiosos buscaram compreender a relação espiritual com a floresta, saber como se dão os rituais e o motivo de serem realizados na floresta. Os grupos religiosos que fazem seus cultos no fragmento foram identificados a partir de vestígios encontrados em clareiras abertas e lixo em alguns pontos do fragmento, além de informações a partir de membros da comunidade da Fazenda. As igrejas que fazem seus rituais no fragmento normalmente os fazem pela madrugada. São elas : Assembléia de Deus, Deus é Amor, Igreja Presbiteriana Renovadora de Campinas e Cruzada, pertencentes à linha pentecostal e neopentecostal, e ainda o Candomblé, da linha do espiritismo. Cada igreja ocupa uma área distinta, sendo identificada como "área de oração". Não existem registros de cultos similares por estas religiões em outras regiões, exceto pela Umbanda, sendo extremamente interessante a abordagem dos motivos que os levam a realizar rituais na floresta (Prof. José Luiz dos Santos, UNICAMP, comunicação pessoal).

O caráter místico da floresta, tradicionalmente considerado por índios e populações tradicionais, confere respeito e sacralização à floresta, o que pode ser importante ao se buscar meios de valorização e conscientização ambiental através de um maior envolvimento e reintegração do ser humano à natureza. No Nepal, diversas religiões associam elementos ambientais com o mundo espiritual, fazem seus ritos em "florestas sagradas", usam e manejam recursos como lenha para alguns rituais e participam da conservação e manejo das florestas (Ingles, 1997). As pessoas envolvidas em rituais na floresta podem ser aliadas no processo de recuperação/conservação. Estas pessoas são, em grande parte, de origem urbana e procuram a 
floresta na busca de "forças espirituais". Este caráter cultural expressa um contexto social que deve ser considerado para um planejamento de ações para recuperação de fragmentos e políticas ambientais. Algumas citações de religiosos participantes dos cultos confirmam a valorização espiritual e sagrada da floresta.

- Os lugares da floresta onde se faz oração têm uma benção maior.

- A biblia explica tudo da natureza : a criação, o dia e a noite, a luz... eu agradeço o poder de Deus ter criado tanta planta como a Cabreúva, Guarantã, Peroba, Jussara e tantas outras.

- Estar na Floresta é ter a natureza do Homem junto da natureza de Deus.

- Jesus andava na terra e tinha doze discípulos. Ele ia orar no monte, por isso nós vamos orar na mata. A mata gosta da nossa oração.

- Na floresta tem o poder.

- A primeira semente veio de Deus. E deu tanta diferença! Tanto bicho, tanta planta...

- A Terra é do senhor! Todo lugar tem árvore e é gerada por Deus.

- Os crentes vão orar na floresta; eles amam muito esta mata e são donos dela também.

- O pessoal por ai só quer saber de plantar cana. o Deus deles é o dinheiro.

- As plantas e os bichos sumiram com tanta poluição; para viver agora, só na graça de Jesus. O mundo está perdido. e daqui para pior.

Todos os participantes dos cultos falam sobre a manifestação do Espírito Santo na floresta. Segundo os relatos, durante os rituais à noite, esta manifestação faz tudo brilhar, os gravetos se acendem e uma força superior se faz presente. Esta força é o motivo das orações na floresta, lugar de poder. Além disso, segundo eles, Jesus Cristo ia orar no monte, e assim eles também vão orar no monte, que aqui é a floresta. Além dos grupos evangélicos que fazem seus cultos no fragmento, são encontradas também oferendas e trabalhos de "macumba". As pessoas desta seita não foram identificadas. Os lugares na floresta onde se realizam os rituais são espalhados, localizam-se geralmente próximo às bordas e existe um sítio para cada igreja.

\section{4 - INSTITUIÇÕES RELACIONADAS}

Diversas instituições governamentais e não-govemamentais de Piracicaba, que têm suas atividades voltadas à área ambiental e exercem alguma influência sobre os fragmentos da região foram identificadas. Esta pesquisa inclui as seguintes instituições : SEDEMA (Secretaria 
Municipal de Defesa do meio Ambiente da Prefeitura Municipal de Piracicaba), SEMA (Secretaria Municipal de Agricultura), SEMAE (Serviço Municipal de Água e Esgoto de Piracicaba), DEPRN (Departamento Estadual de Proteção dos Recursos Naturais), ESALQ (Escola Superior de Agricultura Luiz de Queiroz) e IMAFLORA (Instituto de Manejo e Certificação Florestal e Agrícola). Algumas destas instituições participam do "Grupo de Trabalho Corumbataí", que vem trabalhando em parceria há quase dois anos no intuito de promover a recuperação ambiental da bacia do Corumbataí, rio que fomece água para o município de Piracicaba.

No "workshop de campo" realizado com a presença de membros de algumas instituições e estudantes da ESALQ/USP foi feita uma avaliação do estado de conservação do fragmento Capuava, das áreas de pesquisa deste projeto e a proposição de continuidade de manejo nestas áreas. Nesta ocasião foram levantados os critérios para a avaliação das áreas e foram sugeridas espécies potenciais para a recuperação do fragmento. Os resultados deste "workshop" fizeram parte das avaliações consideradas neste trabalho. A participação dos representantes das instituições foi muito rica pela troca de experiências e conhecimentos em campo. Os participantes elogiaram a iniciativa e mostraram-se satisfeitos com a proposta.

Posteriormente, foram feitas entrevistas com roteiro semi-estruturado aos representantes das instituições para conhecer suas estratégias e ações para a recuperação e conservação de fragmentos florestais em nível local e regional. $\mathrm{O}$ processo das entrevistas levou as pessoas a refletir sobre $\mathrm{o}$ assunto, tomando a troca de idéias rica e produtiva para ambas as partes. $\mathbf{O}$ resultado das entrevistas, além de fomecer idéias e sugestões para a recuperação de fragmentos, reflete a percepção das pessoas acerca da questão e deixa transparecer as ações que estão sendo conduzidas neste sentido. A aglutinação destas informações pode vir a embasar estratégias locais de conservação de fragmentos. As entrevistas estão expostas na íntegra para que o resultado seja expresso da forma mais fiel possível com a riqueza de informações geradas (tabela 24). 
Tabela 24. Entrevistas realizadas a representantes de instituições relacionadas à questão ambiental na região de Piracicaba, SP.

\begin{tabular}{|l|l|}
\hline INSTITUIÇÃO & NOME, PROFISSÃO E CARGO \\
\hline $\begin{array}{l}\text { SEDEMA (Secretaria de Defesa do } \\
\text { Meio Ambiente) }\end{array}$ & $\begin{array}{l}\text { Arlet Nassif, Eng. florestal, Responsável pelo viveiro de } \\
\text { mudas. }\end{array}$ \\
\hline $\begin{array}{l}\text { DEPRN (Departamento Estadual de } \\
\text { Proteção aos Recursos Naturais) }\end{array}$ & $\begin{array}{l}\text { Marcos Fúlvio Ometto, Eng. agrônomo, Supervisor da } \\
\text { equipe técnica. }\end{array}$ \\
\hline $\begin{array}{l}\text { SEMAE (Serviço Municipal de Água e e } \\
\text { Esgoto) }\end{array}$ & $\begin{array}{l}\text { Gilson Luis Merli, Engenheiro, Diretor de produção e } \\
\text { tratamento de água. }\end{array}$ \\
\hline $\begin{array}{l}\text { IMAFLORA (Instituto de Manejo e } \\
\text { Certificação Florestal e Agrícola) }\end{array}$ & $\begin{array}{l}\text { Luis Femando Guedes Pinto, Eng. agrônomo,. } \\
\text { Coordenador do programa de certificação agrícola. }\end{array}$ \\
\hline $\begin{array}{l}\text { SEMA (Secretaria Municipal de } \\
\text { Agricultura) }\end{array}$ & $\begin{array}{l}\text { José Otávio Mentem, Eng. agrônomo, , Secretário de } \\
\text { agricultura. }\end{array}$ \\
\hline $\begin{array}{l}\text { ESALQ/USP (Escola Superior de } \\
\text { Agricultura Luiz de Queiroz) }\end{array}$ & $\begin{array}{l}\text { Leandro Pinheiro, Estudante de Eng. florestal, } \\
\text { Pesquisador do Laboratório de Silvicultura Tropical. }\end{array}$ \\
\hline
\end{tabular}

\begin{tabular}{|l|l|}
\hline 1) & LINHA DE ATUAÇÃO DA INSTITUIÇÃO \\
\hline SEDEMA & $\begin{array}{l}\text { Tudo relativo ao meio ambiente na área urbana : limpeza pública, arborização, } \\
\text { viveiro de mudas, educação ambiental, lixo domiciliar e hospitalar, animais } \\
\text { soltos, implantação e manutenção de sistema de lazer, zoológico e cemitério. }\end{array}$ \\
\hline DEPRN & Licenciador e fiscalizador; age sobre a legislação. \\
\hline SEMAE & Abastecimento de água e coleta e disposição final do esgoto. \\
\hline IMAFLORA & $\begin{array}{l}\text { No setor florestal e agrícola : certificação sócio-ambiental, projetos aplicados e } \\
\text { apoio a desenvolvimento de políticas públicas. }\end{array}$ \\
\hline SEMA & $\begin{array}{l}\text { (i) Abastecimento : varejões e mercados, (ii) Infra estrutura : estradas, pontes e } \\
\text { equipamentos sociais na zona rural (escolas, postos de saúde, etc) e (iii) } \\
\text { Desenvolvimento rural : organização das comunidades e programas de } \\
\text { produção agropecuária sustentada, recuperação de matas ciliares, uma das } \\
\text { grandes preocupações pela conservação dos solos e mananciais, e programa de } \\
\text { educação de "noções de agropecuária" nas escolas de 1 }{ }^{0} \text { a 4 }{ }^{0} \text { série. }\end{array}$ \\
\hline ESALQ/USP & $\begin{array}{l}\text { O Laboratório de Silvicultura Tropical tem coordenação geral do Prof. Virgílio } \\
\text { Viana e desenvolve as seguintes linhas de pesquisa : Fragmentos florestais, } \\
\text { Manejo florestal, Sistemas agroflorestais e Populações tradicionais. }\end{array}$ \\
\hline 2) & $\begin{array}{l}\text { TEM ALGUMA ATUAÇão NA QUESTÃo DOS FRAGMENTOS } \\
\text { FLORESTAIS? QUAL? }\end{array}$ \\
\hline SEDEMA & $\begin{array}{l}\text { Trabalho com a Bacia do Corumbataí e a questão da qualidade da água, o que } \\
\text { puxou o SEMAE para o envolvimento com o trabalho. Alavancou o Grupo de } \\
\text { Trabalho (GT) do Corumbatai, que reúne diversas entidades para projetos de } \\
\text { recuperação da Bacia e do manancial que abastece toda a água de Piracicaba, } \\
\text { em Seminário promovido em 1996. A questão dos fragmentos veio a reboque } \\
\text { da mata ciliar. }\end{array}$ \\
\hline
\end{tabular}




\begin{tabular}{|c|c|}
\hline DEPRN & $\begin{array}{l}\text { Proteção dos fragmentos conforme a legislação. Atua em } 20 \text { municípios, } 9 \\
\text { comarcas e } 14 \text { promotorias de justiça do meio ambiente. Porém, hoje as ações } \\
\text { estão restritas pois só dispõe de dois técnicos e não recebe verba para } \\
\text { combustivel. }\end{array}$ \\
\hline SEMAE & $\begin{array}{l}\text { Ação indireta. Interesse na manutenção das nascentes, trabalho com } \\
\text { reflorestamento ciliar, participação no GT Corumbataí e financiamento de } \\
\text { programa de estudos em técnicas de recuperação de fraginentos florestais. }\end{array}$ \\
\hline IMAFLORA & $\begin{array}{l}\text { Direta não. Indireta: O Projeto Cana visa desenvolver padrões para avaliação e } \\
\text { certificação da cana, que incluem a conservação de ecossistemas naturais. Com } \\
\text { a atividade da certificação, os fragmentos serão avaliados. Nos padrões para } \\
\text { avaliação, monitoramento e certificação sócio-ambiental da cana-de-açúcar e } \\
\text { seu processamento industrial, o principio de conservação de ecossistemas e } \\
\text { proteção da biodiversidade define que "a atividade agrícola deve promover a } \\
\text { conservação de ecossistemas, com especial atenção para a conservação da } \\
\text { biodiversidade e sua recuperação" e o principio de interação com a paisagem } \\
\text { define que "o planejamento, implementação e manejo dos sistemas de } \\
\text { produção agro-industrial devem considerar a inserção da unidade de } \\
\text { produção no meio fisico e biológico regional, visando integração e } \\
\text { estabilidade a longo prazo". }\end{array}$ \\
\hline SEMA & $\begin{array}{l}\text { Na Bacia do Corumbatai fez o plantio de } 80.000 \text { árvores em convênio com } \\
\text { Usinas e particulares. O projeto inicial previa apenas as margens do rio, mas } \\
\text { em contatos com o Prof. Virgilio Viana, ESALQ, readaptou-se o projeto para a } \\
\text { recuperação de fragmentos e a união entre eles também. }\end{array}$ \\
\hline ESALQ/USP & $\begin{array}{l}\text { Pesquisa e divulgação científica. Linha principal de pesquisa: } \\
\text { geoprocessamento aplicado ao diagnóstico de fragmentos florestais. }\end{array}$ \\
\hline 3) & $\begin{array}{lcccc}\text { QUE } & \text { ESTRATÉGIAS } & \text { CONSIDERA } & \text { IMPORTANTES } & \text { PARA } \\
\text { SOLUCIONAR A PROBLEMÁTICA DOS FRAGMENTOS? } & \\
\end{array}$ \\
\hline SEDEMA & $\begin{array}{l}\text { Incentivos aos proprietários e educação ambiental com os proprietários e as } \\
\text { pessoas que moram em tomo dos fragmentos. }\end{array}$ \\
\hline DEPRN & $\begin{array}{l}\text { Averbação dos fragmentos, além do que exige o artigo } 16 \text { do Código Florestal. } \\
\text { Não dar autorização para derrubada ou manejo sem que o fragmento tenha sido } \\
\text { averbado. }\end{array}$ \\
\hline SEMAE & $\begin{array}{l}\text { Estratégias amplas com planejamento territorial rural e urbano, legislação } \\
\text { ambiental, conscientização integrada para comunidade, alunos e trabalhadores, } \\
\text { educação ambiental, valorizar os fragmentos inserindo-os no dia-a-dia das } \\
\text { pessoas com a questão da qualidade de vida, políticas voltadas para recuperar } \\
\text { com manejo correto ("já destruímos, agora tem que refazer"), e pesquisas. } \\
\text { Deve-se pensar a nível macro envolvendo bacias e cidades numa escala ampla. }\end{array}$ \\
\hline IMAFLORA & $\begin{array}{l}\text { Estimulo econômico, reconhecimento do valor, importância e relação com a } \\
\text { qualidade de vida, políticas públicas que contemplem as demandas econômicas, } \\
\text { educação ambiental, uso dos fragmentos e pesquisa. Como contemplar da } \\
\text { escala de fazenda à escala de paisagem para a legislação? }\end{array}$ \\
\hline SEMA & $\begin{array}{l}\text { A principal é a conscientização do agricultor. Deve-se envolver o proprietário } \\
\text { rural nos projetos de replantio. Hoje é o maior entrave, pois falta colaboração } \\
\text { na manutenção das árvores plantadas. Geralmente reconhecem a questão legal, } \\
\text { mas a contrapartida não vem ocorrendo. Sem a participação deles não tem }\end{array}$ \\
\hline
\end{tabular}




\begin{tabular}{|c|c|}
\hline & como fazer recuperação. \\
\hline ESALQ/USP & $\begin{array}{l}\text { Desenvolvimento de métodos de baixo custo para recuperação e criação de } \\
\text { políticas públicas para a valorização dos fragmentos. }\end{array}$ \\
\hline 4) & $\begin{array}{l}\text { O QUE É FEITO EM NÍVEL DE POLÍTICAS PÚBLICAS ACERCA } \\
\text { DA QUESTÃO DOS FRAGMENTOS E DESMATAMENTO? }\end{array}$ \\
\hline SEDEMA & $\begin{array}{l}\text { Tentativa de amarrar a nível de políticas públicas a preservação de áreas } \\
\text { verdes particulares. Foi criada no Estado a Lei ARIE (áreas de relevante } \\
\text { interesse ecológico) que dava descontos no IPTU em propriedades com } \\
\text { fragmentos em áreas urbanas, mas ficou inóqua. }\end{array}$ \\
\hline DEPRN & $\begin{array}{l}\text { Legislação : Código florestal e Decreto } 750 \text {. Há uma carência de material legal } \\
\text { para cerrado e várzea. }\end{array}$ \\
\hline SEMAE & $\begin{array}{l}\text { Acho que não é feito. Houve uma mudança na legislação (federal, estadual e } \\
\text { municipal), mas ainda falta muito. Tem a lei de proteção dos mananciais. Está } \\
\text { em discussão um projeto que prevê o recolhimento de } 1 \% \text { da tarifa de água da } \\
\text { população para a recuperação de áreas ciliares. }\end{array}$ \\
\hline IMAFLORA & $\begin{array}{l}\text { Plano de zoneamento e prioridades de recuperação, iniciativa da Secretaria de } \\
\text { meio ambiente do Estado. Em Piracicaba, o Grupo de trabalho Corumbataí } \\
\text { vem discutindo isso. }\end{array}$ \\
\hline SEMA & $\begin{array}{l}\text { A principal política pública é a atividade da SEMA com reflorestamento ciliar. } \\
\text { Com recursos da secretaria, que estão no orçamento, e outras autarquias como } \\
\text { o SEMAE, está se desenvolvendo um trabalho. Há maior probabilidade de } \\
\text { viabilizar a floresta aproveitando as já existentes, bem ou mal elas ainda tem } \\
\text { diversidade. Fazendo corredores a fauna remanescente fica e há maior } \\
\text { probabilidade de recuperação natural. }\end{array}$ \\
\hline ESALQ/USP & Deve-se criar políticas públicas para a valorização dos fragmentos. \\
\hline 5) & $\begin{array}{l}\text { QUE OUTROS PROBLEMAS AMBIENTAIS CONSIDERA GRAVES } \\
\text { NA REGIÄO? }\end{array}$ \\
\hline SEDEMA & Água e fauna (biodiversidade). \\
\hline DEPRN & $\begin{array}{l}\text { Água mais que o ar. } 0 \text { licenciamento deve ser global, incluindo água em } \\
\text { quantidade e qualidade e ar. }\end{array}$ \\
\hline SEMAE & $\begin{array}{l}\text { Tratamento do esgoto doméstico e industrial, as queimadas da cana, resíduos } \\
\text { sólidos públicos e industriais e a falta de conscientização. }\end{array}$ \\
\hline IMAFLORA & Esgoto (saneamento), erosão, queimadas e qualidade da água. \\
\hline SEMA & $\begin{array}{l}\text { Erosão é o problema mais grave. Há uma perda de cerca de } 2 \text { milhões de } \\
\text { toneladas de solo por ano, e um dos grandes responsáveis por isto é o uso } \\
\text { inadequado dos solos. A cana é plantada em lugares indevidos e culturas } \\
\text { inadequadas são plantadas onde deveria Ter mata ou culturas perenes. Hoje } \\
\text { existe apenas } 6 \% \text { de matas ciliares protegendo os rios, e a água das casas nas } \\
\text { estradas também contribui para a erosão. Em segundo lugar, o problema do } \\
\text { lixo. Há uma grande falta de educação neste sentido, muito lixo nas beiras das } \\
\text { estradas. A SEMA está reciclando embalagens de defensivos. }\end{array}$ \\
\hline ESALQ/USP & Proteção de mananciais e cursos d'água e poluição industrial \\
\hline
\end{tabular}




\begin{tabular}{|c|c|}
\hline 6) & CONHECE O FRAGMENTO CAPUAVA? \\
\hline SEDEMA & Sim. \\
\hline DEPRN & Contato diário e distante. Vejo-o da estrada. Me chama atenção. \\
\hline SEMAE & Sim. \\
\hline IMAFLORA & Sim \\
\hline SEMA & Sim \\
\hline ESALQ/USP & Sim \\
\hline 7) & O QUE ACHA QUE DEVE SER FEITO PARA ESTE FRAGMENTO? \\
\hline SEDEMA & $\begin{array}{l}0 \text { que se deve fazer em todos : enriquecer, manejar e proteger, de acordo com } \\
\text { as técnicas recomendadas. }\end{array}$ \\
\hline DEPRN & $\begin{array}{l}\text { Averbação e maior isolamento das áreas de cana (o carreador é de três metros, } \\
\text { previsto por lei, eu colocaria o dobro). }\end{array}$ \\
\hline SEMAE & $\begin{array}{l}\text { Deveria ser ampliado, ligando-se a outros próximos a ele. Como? Através de } \\
\text { parcerias entre empresa, proprietário, prefeitura, Universidade, comunidade... } \\
\text { Grupos que vissem a importância e lutassem por isso. }\end{array}$ \\
\hline IMAFLORA & $\begin{array}{l}\text { Manter as pesquisas a longo prazo, pois este fragmento já é referência e deve- } \\
\text { se preservar isto. Fazer experiências para dar bases científicas ao manejo, e } \\
\text { conservá-lo com estratégias de conservação. }\end{array}$ \\
\hline SEMA & $\begin{array}{l}\text { Deveria ser recuperado e fazer uma utilização das áreas incorporadas à } \\
\text { floresta. Existe um grande potencial para turismo rural. }\end{array}$ \\
\hline ESALQ/USP & $\begin{array}{l}\text { Recuperação das áreas mais degradadas, plantios de bordadura, conectá-lo } \\
\text { com outro remanescente e aceiro contra fogo. }\end{array}$ \\
\hline 8) & COMO VOCÊ PODERIA CONTRIBUIR PARA ISTO? \\
\hline SEDEMA & $\begin{array}{l}\text { Continuando a fazer o que estou tentando fazer através do GT Corumbataí. } \\
\text { Para que esta Bacia seja modelo e passe a idéia para outros municípios. Se as } \\
54 \text { cidades da Bacia do Piracicaba fizessem a mesma coisa, seria um pulo de } \\
\text { qualidade... }\end{array}$ \\
\hline DEPRN & Pode contar com o Departamento. \\
\hline SEMAE & $\begin{array}{l}\text { Em dois níveis: enquanto empresa, o SEMAE quer apoiar atividades que } \\
\text { tentam melhorar, preservar, conservar. Houve uma mudança de visão em } \\
\text { relação a fragmentos e abastecimento de água, logo, mudou-se a forma de } \\
\text { tratar a questão. Como cidadão, em termos práticos, buscar eleger pessoas } \\
\text { para cargos govemamentais que defendam a questão, participar de grupos e } \\
\text { denunciar. }\end{array}$ \\
\hline IMAFLORA & $\begin{array}{l}\text { A intenção é contribuir, sinto-me responsável por sua qualidade, mas não sei } \\
\text { qual minha liberdade Está em área privada e não sei como contribuir } \\
\text { diretamente. }\end{array}$ \\
\hline SEMA & $\begin{array}{l}\text { Pondo a secretaria à disposição para programas de turismo rural, com } \\
\text { assessoria e parceria. Identificar pontos de destaque turístico, pesque e pague, } \\
\text { roteiros e estradas integradas. }\end{array}$ \\
\hline ESALQ/USP & Fazendo um planejamento detalhado baseado em informações espaciais. \\
\hline
\end{tabular}


Este levantamento feito com as instituições contribuiu para identificar vínculos entre as entidades e as ações realizadas e visa incentivar a elaboração de atividades em conjunto e a criação de políticas públicas que contribuam efetivamente para a recuperação de fragmentos florestais na região. Entre as estratégias sugeridas pelos representantes das instituições estão: incentivos econômicos para a preservação, políticas públicas, legislação, estratégias integradas a nivel de bacia hidrográfica, pesquisas com metodologias para recuperação a baixo custo e conscientização e educação ambiental. Cada pessoa, com sua contribuição, expôs seu ponto de vista, indicou estratégias relacionadas com suas respectivas áreas de atuação e demonstrou disponibilidade e interesse em participar de alguma forma em planos de recuperação, conservação e conscientização ambiental. Atualmente, cada vez mais são necessárias as parcerias, as ações integradas e em conjunto, o trabalho inter e trans-disciplinar, a soma de esforços e a cooperação entre os seres.

"Um mais um é sempre mais que dois..."

Beto Guedes

\section{CONCLUSÕES}

Pessoas e instituições relacionam-se com o fragmento Capuava de diversas formas, com propósitos distintos, podendo vir a ser agentes no processo de conservação e recuperação ambiental. As relações e o conhecimento sobre a floresta diferem muito de acordo com as características das pessoas e instituições e seu vínculo com o fragmento. $\mathbf{O}$ proprietário expressa vontade de conservar o fragmento e outras áreas de preservação da fazenda, além de plantar corredores e matas ciliares. Na comunidade de moradores da fazenda, poucos têm vínculo direto com o fragmento, mas julgam-no importante principalmente pela qualidade do ar e preservação dos animais. Consideram que não está degradado, não fazem uso de nenhum produto da floresta e pouco a freqüentam. Os grupos de pessoas que visitam o fragmento têm diversas motivações, como a caça, as atividades espirituais, as pesquisas ou o lazer. Os diversos grupos religiosos têm relação direta com a floresta e um vínculo afetivo e espiritual; freqüentam periodicamente o fragmento nos rituais que se dão semanalmente principalmente pela madrugada. As instituições com atividades ambientais na região de Piracicaba estão desenvolvendo diversas ações no sentido da recuperação de fragmentos, cada uma em sua área específica de atuação. Podem vir a integrar as ações em parcerias e cooperações inter-institucionais para recuperação dos fragmentos. Os 
técnicos destas instituições contribuíram com diversas sugestões para a solução da problemática dos fragmentos na região. Entre as sugestões destacam-se mecanismos de valorização das florestas, incentivos legais, fiscais e econômicos para a recuperação e conservação, pesquisas e ampla conscientização.

\section{CONSIDERAÇÕES FINAIS}

A abordagem participativa utilizada e as pesquisas conduzidas no fragmento constituem concretamente uma etapa inicial para o planejamento da recuperação do fragmento com a participação dos "grupos de interesse". As intervenções para recuperação e conservação dos fragmentos florestais devem considerar a complexidade de relações, eventuais conflitos e potenciais parcerias. Os fragmentos não estão num vazio social, mas estão inseridos num meio sócio-econômico-cultural que participa de sua dinâmica. Mecanismos de envolvimento das pessoas e instituições na recuperação permitirão que estes atores sociais sintam-se parte do problema e da solução e, mais do que "grupos relacionados" à floresta, possam vir a se tomar "guardiões da floresta", conferindo aos fragmentos uma esperança em termos de recuperação e sustentabilidade. 


\title{
CAPÍtULO V CONSIDERAÇÕES FINAIS
}

\author{
"A floresta tropical tem 1000 teses que dormem..." \\ Roelof Oldeman
}

\section{CONSIDERAÇÕES FINAIS}

A fragmentação florestal, os efeitos dela decorrentes e a necessidade de manejo para recuperação do pouco que ainda resta de nossas florestas, são temas de grande relevância mundial atualmente. A ciência deve caminhar junto à realidade, buscando questões de importância concreta e prática para seu próprio desenvolvimento. No caso desta pesquisa, o desafio partiu do problema que atinge grande parte das áreas de domínio de Mata Atlântica e começa a ameaçar a Amazônia : o desmatamento em grande escala e a fragmentação florestal. Diversos estudos vêm se desenvolvendo nestes dois grandes ecossistemas e as conclusões são alarmantes no sentido de uma transformação acelerada que causa grandes impactos nos remanescentes de florestas. $\mathbf{O}$ efeito, sentido por todos organismos, resulta um processo de degradação que nem sempre é reversível, requerendo intervenções para auxiliar a auto-sustentação dos ecossistemas. Este trabalho obteve resultados importantes quanto às principais questões do assunto tratado e trouxe contribuições ao avanço científico em técnicas e princípios no manejo para recuperação de fragmentos florestais. A geração de conhecimentos baseada em erros e acertos de uma experiência traz resultados práticos que podem ser aplicados no panorama real.

No trabalho experimental realizado, pode-se tecer as seguintes conclusões:

(i) 0 manejo proposto para as capoeiras baixas, baseado na poda de cipós e plantio de espécies agrícolas e florestais, revelou-se acelerador da sucessão, possibilitando que espécies nativas que não conseguiam ter seu recrutamento efetivado por impedimento físico e/ou biológico conseqüente de efeitos da fragmentação, pudessem colonizar as áreas, alavancando a sucessão. As áreas com 
manejo apresentaram maior densidade e riqueza de espécies arbóreas recrutadas do que as testemunhas.

(ii) As espécies recrutadas, tanto nas áreas com manejo como nas testemunhas, pertencem a diversos grupos ecológicos e representam uma riqueza biológica significativa. Nas áreas testemunhas, porém, observa-se menor densidade de plântulas e menos condições para o desenvolvimento futuro destas.

(iii) As árvores pré-existentes nas áreas de capoeira baixa apresentam alto índice de mortalidade por quebra a partir de ventos, raios e peso dos cipós. As espécies arbóreas representam uma grande riqueza, mas a área basal das capoeiras baixas é muito pequena em relação às áreas mais conservadas do fragmento.

(iv) As mudas plantadas no tratamento 2 (poda dos cipós e plantio agroflorestal) apresentaram bom desenvolvimento, com alto índice de crescimento em altura e diâmetro da copa, tanto nas áreas de borda como no interior do fragmento. As espécies foram adequadamente escolhidas e contribuem para a recomposição estrưural da capoeira baixa, promovendo maior diversidade de nichos e enriquecendo o fragmento com diversidade genética.

(v) As espécies agrícolas escolhidas não tiveram bom desenvolvimento de forma geral. Somente seis das vinte áreas apresentaram produção agrícola viável. Nas demais áreas houve crescimento vegetativo sem frutificação ou produção de frutos com doenças. As espécies escolhidas mostraram-se adaptadas para situações de algumas eco-unidades nas áreas e exerceram papel de bio-indicadoras da heterogeneidade das parcelas.

(vi) Não houve uma compensação efetiva dos custos da recuperação das áreas; a receita da produção agrícola representou $10 \%$ dos gastos, que se deram principalmente com o pagamento da mão-de-obra.

Este trabalho foi uma iniciativa pioneira e acena com perspectivas para experiências que testem o plantio de outras espécies agrícolas e nativas, possibilitando aumentar a produção. Existe a necessidade da seleção de variedades agrícolas adaptadas a ambientes heterogêneos como as capoeiras baixas. A heterogeneidade ambiental revelou a dinâmica ocorrente nos fragmentos florestais em que as eco-unidades fragmentam-se rapidamente e tomam diversos caminhos de desenvolvimento. As parcelas estabelecidas subdividiram-se em sítios, gerando novas pequenas eco-unidades que levou à uma grande diferença entre as parcelas e dentro delas. As eco-unidades foram caracterizadas principalmente pela diferença na densidade e composição da regeneração 
natural, frưto da interação das espécies presentes com o ambiente diferenciado. A partir de um estado inicial semelhante, as capoeiras baixas apresentaram-se em distintas fases de desenvolvimento após um ano : (i) fase inicial, com alta densidade e baixa diversidade de regeneração natural, (ii) fase de degradação, com baixa densidade e diversidade de regeneração, com grande reocupação dos cipós e manutenção do dossel aberto, e (iii) fase de agradação, com alta diversidade e densidade de espécies, representando um avanço na sucessão inicial.

A complexidade dos fragmentos florestais e de todas florestas tropicais, requer um refinamento na diagnose e no manejo para recuperação e conservação. $O$ entendimento dos processos sucessionais e da dinâmica das eco-unidades pode auxiliar o manejo, que não tem receita nem modelo e deve ser tão heterogêneo e complexo quanto a própria floresta. Isto não deve, no entanto, impedir que intervenções sejam feitas, mas é importante garantir que as atitudes tomadas estejam seguindo o fluxo da sucessão. As novas versões dos sistemas agroflorestais para recuperação de capoeiras baixas devem ser aprimoradas a partir das lições aqui descritas com relação às respostas, falhas, acertos e percepções expressas ao longo do trabalho.

Além da avaliação ecológica da resposta aos tratamentos testados, a abordagem feita com as instituições e pessoas envolvidas com o fragmento contribuiu para a compreensão dos níveis de relação e as percepções quanto ao estado do fragmento e com sugestões de estratégias para a recuperação do fragmento Capuava e outros. Esta análise mostrou-se importante pela busca da adequação da pesquisa ao contexto sócio-cultural, a divulgação deste trabalho e a conscientização da importância da conservação dos fragmentos. A participação dos atores sociais do cenário em questão gera a possibilidade da criação de vínculos e parcerias, o que pode contribuir para viabilizar projetos de recuperação ambiental.

\section{PRIORIDADES DE PESQUISAS}

As pesquisas devem ser feitas para resolver questões e conflitos, e precisam estar mais comprometidas ideologicamente com os rumos da Terra e com o poder que a Ciência pode ter para o desenvolvimento. $\mathbf{O}$ planeta vive um momento peculiar nas relações do Homem com seus recursos. Os pesquisadores devem endereçar suas questões para que tenham relevância prática para quem maneja os recursos e assegurar que suas pesquisas tornem-se disponíveis para quem atua na prática (Crome, 1997; Bierregaard et al., 1997). 
Um dos aspectos mais dificeis dos estudos em fragmentação é a dimensão do assunto que envolve diferentes escalas hierárquicas, macro e micro, na paisagem em que se encontra. A natureza, a direção e a magnitude dos efeitos da fragmentação são extremamente dificeis de predizer dada a complexidade das interações ecológicas e a natureza não-linear de muitas interações. $\mathbf{O}$ caminho das técnicas estatísticas clássicas para análise nem sempre são apropriadas para estudos em fragmentos pois o tema é muito complexo. Alguns problemas para a pesquisa em fragmentos são relacionados com a complexidade : (i) em geral há um desconhecimento do sistema intacto, antes da fragmentação, (ii) o curto período de análise das pesquisas é insuficiente para o estudo de determinadas espécies (ex. árvores) e (iii) há dificuldade de generalizações dada a unicidade de cada paisagem em seu padrão de fragmentação, atividades desenvolvidas na matriz, composição da biota e os vários efeitos da fragmentação (Crome, 1997).

São necessárias pesquisas em diversas regiões, abrangendo distintas áreas de conhecimento, para se chegar a uma compreensão mais global dos efeitos da fragmentação e de estratégias para recuperação. Já que a maior parte dos impactos nos fragmentos originam-se da paisagem ao redor, há uma clara necessidade de olhar na direção do manejo integrado da paisagem (Saunders et al., 1991). A paisagem deve ser vista como um sistema vivo, sem as fronteiras sócio-econômicas, respeitando principalmente as fronteiras biológicas. $\mathbf{O}$ manejo ecológico dos mosaicos da paisagem deve ser feito em função do potencial natural de cada ecounidade através do gerenciamento da tendência de fragmentação natural dos ecossistemas (Viana et al., 1998). Os habitats da matriz diferenciam-se em atributos-chave que afetam os fragmentos, como a capacidade de permitir o fluxo gênico para espécies florestais, prover habitat para a fauna silvestre e a proteção física de extremos climáticos (Laurance et al., 1997).

A necessidade de pesquisas para recuperação de fragmentos inclui a identificação de barreiras para a sucessão natural em sítios específicos, a definição das condições em que os métodos de recuperação possam alcançar resultados favoráveis, o valor do plantio de corredores para facilitar a troca genética, métodos para acelerar a sucessão e práticas de manejo em áreas severamente degradadas que resultem em florestas secundárias ricas em espécies e produtivas (Lamb et al., 1997). Há uma série de tópicos-chave para pesquisas em fragmentos considerando metodologias, necessidades em nível de espécies, tópicos em nível de comunidades, manejo e conservação de recursos e aspectos sócio-econômicos (Bierregaard et al., 1997). Estas prioridades de pesquisa estão baseadas no acúmulo de informações geradas até o momento, na difículdade de 
generalizações frente à complexidade da questão e nos "gargalos" que vão surgindo a cada novo passo dado nesta ciência.

Como sugestão para outros trabalhos de pesquisa a partir dos resultados e discussões aqui levantados estão :

(i) a continuidade do acompanhamento da regeneração natural e dinâmica de eco-unidades nas áreas estudadas, (ii) o estudo de características ecológicas e demográficas das espécies recrutadas, (iii) a continuidade do manejo nas áreas, com atenção às medidas ergonométricas, para definir a intensidade de trabalho e os custos das operações, (iv) a seleção e o plantio de outras espécies e variedades agrícolas em experimentos semelhantes em capoeiras baixas, considerando as ecounidades e sua dinâmica, (v) o plantio de outras espécies arbóreas nativas, incluindo o plantio por sementes, o plantio em consórcios e o manejo das plântulas recrutadas no fragmento, (vi) o manejo das bordas do fragmento, com controle de cipós e plantio agroflorestal, (vii) a implantação de uma zona tampão adjacente ao fragmento, (viii) o planejamento da recuperação geral do fragmento a partir dos eco-mosaicos, (ix) o estabelecimento de corredores unindo outros fragmentos próximos e (x) trabalhos participativos envolvendo os grupos, pessoas e instituições relacionadas com o fragmento.

\section{PRIORIDADES NA RECUPERAÇÃO DE FRAGMENTOS}

Para a recuperação do fragmento Capuava recomenda-se : manejo das bordas do fragmento com poda de cipós, plantio agroflorestal numa faixa adjacente às bordas criando uma zona tampão entre o fragmento e a cultura da cana-de-açúcar, plantio de um corredor unindo este fragmento a outro existente na fazenda e plantio de matas ciliares ao redor da represa e ao longo do rio. Sugere-se também a realização de atividades de turismo rural e educação ambiental, podendo-se controlar a entrada de pessoas no fragmento, contribuir para a conscientização ambiental e obter receita para projetos de recuperação ambiental na fazenda. As pesquisas devem prosseguir neste fragmento em função do acúmulo de informações geradas até o momento e a possibilidade de obter dados em parcelas permanentes, com longo período de acompanhamento.

Para a recuperação de fragmentos de modo geral, é fundamental o desenvolvimento de estratégias que possam, de forma rápida, começar a transformar o quadro atual de fragmentação das paisagens e degradação dos fragmentos. $\mathrm{O}$ processo de desmatamento e destruição dos ecossistemas naturais deu-se de forma muito abrupta e decisiva; os efeitos conseqüentes ocorrem 
igualmente rápido, sendo urgente a tomada de medidas mitigadoras deste problema antes que o quadro seja irreversível. $\mathbf{O}$ estabelecimento de estratégias e prioridades para a restauração de florestas secundárias é um exercício dificil dada a complexidade resultante da heterogeneidade dos ambientes biofísicos e sócio-econômicos e a dinâmica temporal em que estes ecossistemas se inserem (Viana, 1998). Para as estratégias de recuperação são necessárias ações integradas e conjuntas que trabalhem em diferentes escalas ao mesmo tempo e que partam de uma visão holística sobre a questão.

Entre as propostas para estratégias de recuperação de fragmentos consideradas prioritárias estão :

(i) o envolvimento e conscientização dos proprietários e população relacionada ao fragmento e à paisagem nos projetos de recuperação e conservação, (ii) o planejamento em nível de paisagem, com o plantio de corredores ligando fragmentos, assegurando a porosidade da paisagem ao possibilitar o fluxo gênico e as funções com relação à topografia e os recursos hídricos, (iii) o manejo de eco-mosaicos degradados dos fragmentos, principalmente as bordas, com o controle de cipós e plantio de espécies nativas e agrícolas adequadas à situação e (iv) o plantio de áreas adjacentes aos fragmentos, criando uma zona tampão, e áreas ciliares, seguindo a estratégia da sucessão, com o uso de espécies nativas locais em consórcios e espécies agrícolas se houver desejo de produção aliada à recuperação.

A questão ecológica remete a um novo nível da consciência mundial: a importância da Terra como um todo, o bem comum das pessoas, das sociedades e do conjunto dos seres da natureza. As estratégias para recuperação ambiental fazem parte deste novo paradigma que busca o equilíbrio universal e a nova ordem ecológica mundial !

"Vivemos tempos criticos. Por isso criativos. Nos últimos anos mudou a cartografia politica e ideológica mundial. Estruturas ruiram e com elas muitos esquemas mentais. Ficaram os sonhos. Como pertencem à substância do ser humano, eles sempre ficam. Permitem novas visões e fornecem o entusiasmo necessário para o pensamento e a criatividade” (Boff, 1993). 


\section{REFERÊNCIAS BIBLIOGRÁFICAS}

BAZZAZ, F. A. Plants in changing environments - linking physiological, population, and community ecology. Cambridge University Press, 1996. 320p.

BECKER, H. Métodos de pesquisa em ciências sociais. São Paulo, Editora Hucitec, 1994. $177 \mathrm{p}$.

BIERREGAARD, R. O., LOVEJOY, T. E., KAPOS, V., SANTOS, A. A. \& HUTCHINGS, R. $W$. The biological dynamics of tropical rainforest fragments - a prospective comparison of fragments and continuous forest. Bioscience, 42, 11: 859-866. 1992.

BIERREGAARD, R. O., LAURANCE, W. F.,SITES, J. W. et al. Key priorities for the study of fragmented tropical ecosystems. In: LAURANCE, W., BIERREGAARD, R. O. \& MORITZ, C. (Ed.) Tropical forest remnants - ecology, management, and conservation of fragmented communities. The University of Chicago Press, 1997. p.515-526.

BOFF, L. Ecologia - mundialização - espiritualidade. São Paulo, Ed. Ática. 1993. 180p.

BRANDÃO, C. R. Pesquisa participante. São Paulo, Ed. brasiliense, 1981. 280 p.

BRASÍLIA RURAL. Brasília: Secretaria de agricultura do distrito federal. Ano 2, n. 2, set.1996.

BROKAW, N. V. L. Gap-phase regeneration in a tropical forest. Ecology, 66, n.3. p. 682-687. 1985a.

BROKAW, N. V. L. Treefalls, regrowth, and community structure in Tropical forests. In : PICKETT, S. T. \& WHITE, P. S. (Ed.) The ecology of natural disturbance and patch dynamics. p. 53-69, cap. 4 . 1985 b.

BUDOWSKI, G. Distribution of tropical american rain forest species in the light of successional processes. Turrialba. Turialba. 15(7), 40-42, 1965.

CAIRNS, J. Restoration, reclamation and regeneration of degraded or destroyed ecosystems. In: SOULÉ, M. E. (ed.) Conservation Biology, the science of scarcity and diversity. Sinauer Associates, Inc. Sunderland, Massachusetts. 1986. cap. 23, p. 465-484. 
CATHARINO, E. L. M. Estudos fisionômico-florísticos e fitossociológicos em matas residuais secundárias no município de Piracicaba, SP. Campinas, 1989, 181p. Tese (Mestrado), Universidade Estadual de Campinas.

CLARK, D. A. \& CLARK, D. B. Análisis de la regeneración de árboles del dosel en bosque muy húmedo tropical: aspectos teóricos y prácticos. Revista de Biologia Tropical, 35 (supl.1): 41-54, 1987.

COLFER, C. J. P. Who counts most in sustainable forest management ? CIFOR - Center for international forestry research. Working paper no.7, Indonesia, 1995.

CRESTANA, M. S. M. Florestas - sistemas de recuperação com essências nativas. CATI, Campinas, 1993. 60p.

CROME, F. H. Researching tropical forest fragmentation: shall we keep on doing what we're doing? In: LAURANCE, W., BIERREGAARD, R. O. \& MORITZ, C. (Ed.) Tropical forest remnants - ecology, management, and conservation of fragmented communities. The University of Chicago Press, 1997. p. 485-501.

DEAN, W. A ferro e fogo. São Paulo, Ed. Companhia das letras, 1996. 484p.

DENSLOW, J. S. Gap partitioning among tropical rainforest trees. Biotropica, 12 (supl.): 47-55, 1980.

DENSLOW, J. S. Disturbance and diversity in tropical rain forests : the density effect. Ecological Applications, 5 (4), p.962-968, 1995.

DUBOIS, J. C. Manual de Sistemas agroflorestais. Rio de Janeiro, REBRAF, 1996. 228p.

FALS BORDA, O. Aspectos teóricos da pesquisa participante. In : CARLOS BRANDÃo (org.) Pesquisa participante. São Paulo, Ed. Brasiliense, 1991.

FAO Tropical Forests Resources. FAO, Roma-Itália.1991. 
FERRETI, A., KAGEYAMA, P., ÁRBOEZ, G., SANTOS, J. D., BARROS, M. I., LORZA, R. \& OLIVEIRA, C. Classificação das espécies arbóreas em grupos ecológicos para revegetação com nativas no Estado de São Paulo. Florestar Estatístico, v.3, n.7, p.73-77, mar./jun. 1995.

GAJASENI, J. MATTA-MACHADO, R. \& JORDAN, C. F. Diversified agroforestry systems: buffers for biodiversity reserves, and landbridges for fragmented habitats in the tropics. In: ROBERT C. SZARO \& DAVID W. JOHNSTON (Ed.) Biodiversity in managed landscapes: Theory and practice. Oxford University Press- New York, 1996. cap.32, p.506-513.

GALLI, F., TOKESHI, H. CARVALHO, P. C. T., BALMER, E., KIMATI, H., CARDOSO, C. O. N. \& SALGADO, C. L. Manual de fitopatologia: doenças das plantas e seu controle. São Paulo, Agronômica Ceres, 1968. 640p.

GOMEZ-POMPA, A. \& VÁSQUEZ-YANES, C. Estudios sobre sucession secundaria en los tropicos calido-humedos: el ciclo de vida de las especies secundarias. In: GÓMEZ-POMPA et al. Investigaciones sobre la regeneracion de selvas altas en Vera Cruz, Mexico. 1976. p.579-593.

GÖTSCH, E. O Renascer da agricultura. AS-PTA, Rio de Janeiro.1995. 22p.

GRIMBLE, R. \& CHUAN MAN-KWUN Stakeholder analysis for natural resource management in developing countries - some pratical guidelines for making management more participatory and effective. Natural Resources Forum, v.19, n.2, 1995. p.113-124.

HART, R. D. A natural ecosystem analog approach to the design of a successional crop system for tropical forest environments. Biotropica 12, 2, p.73-82. 1980.

HIGGS, E. Expanding the scope of restoration ecology. Restoration Ecology, v.2, n. 3, 1994. p. 137-146.

IBGE. Manual técnico da vegetação brasileira. Manuais Técnicos em Geociências 1: 1-91. 1992. 
INGLES, A. W. The influence of religious beliefs and rituals on forest conservation in Nepal. In: KLAUS SEELAND (Ed.) Nature is culture. Intermediate technology publications, 1997. cap. 7, p.57-66.

JANZEN, D. Management of habitat fragments in a tropical dry forest. Annual Missouri Botanical Garden 75, p.105-116. 1988.

JANZEN, D. Regrowing a dry tropical forest. Science 234, p.809-810. 1986.

JESUS, R. M. Recuperação de áreas degradadas. II CONGRESSO NACIONAL SOBRE ESSÊNCIAS NATIVAS, Anais. São Paulo. 1992. p. 407-412.

KAGEYAMA, P. Y. \& CASTRO, C. Sucessão secundária, estrutura genética e plantações de espécies nativas. IPEF, 41/42, p.83-93. 1989.

KAGEYAMA, P. K. \& GANDARA, F. B. Dinâmica de populações de espécies arbóreas: implicações para o manejo e a conservação. III SIMPÓSIO DE ECOSSISTEMAS DA COSTA BRASILEIRA, ACIESP, 1993.

KAGEYAMA, P. Y., SANTARELLI, E. GANDARA, F., GONÇALVES, J. C., SIMIONATO, J. L., ANTIQUEIRA, L. R. \& GERES, W. L. Revegetação de áreas degradadas: modelos de consorciação com alta diversidade II SIMPÓSIO NACIONAL DE RECUPERAÇÃO DE ÁREAS DEGRADADAS, Anais. Foz do Iguaçu, Paraná. 1994. 8p.

KAGEYAMA, P. Y. \& VIANA, V. Tecnologia de sementes e grupos ecológicos de espécies arbóreas tropicais. Apresentado no II SIMPÓSIO BRASILEIRO SOBRE TECNOLOGIA DE SEMENTES FLORESTAIS, São Paulo, 1989. 19 p.

KAPOS, V. Effects of isolation on the water status of forest patches in the Brazilian amazon. Journal of Tropical Ecology, Cambridge, v. 5, n. 2, p.173-185. 1989.

KAPOS, V., WANDELLI, E., CAMARGO, J. L. \& GANADE, G. Edge related changes in environment and plant responses due to forest fragmentation in central Amazonia. In : LAURANCE, W., BIERREGARD, R. O. \& MORITZ, C. (Ed.) Tropical forest remnantsecology, management, and conservation of fragmented communities. The University of Chicago Press, 1997. p.33-44. 
LAMB, D., PARROTTA, J. , KEENAN, R. \& TUCKER, N. Rejoining habitat remnants: restoring degraded rainforest lands. In : LAURANCE, W., BIERREGARD, R. O. \& MORITZ, C. (Ed.) Tropical forest remnants - ecology, management, and conservation of fragmented communities. The University of Chicago Press, 1997. p.366-386.

LAURANCE, W. F., BIERREGAARD, R. O., GASCON, C. et al. Tropical forest fragmentation: synthesis of a diverse and dynamic discipline. In : LAURANCE, W., BIERREGARD, R. O. \& MORITZ, C. (Ed.) Tropical forest remnants - ecology, management, and conservation of fragmented communities. The University of Chicago Press, 1997. p.502-514.

LE FLOC'H, E. \& ARONSON, J. Écologie de la restauration. Définition de quelques concepts de base. Natures - Sciences - Sociétés, Hors-serie, 1995. p. 29-35.

LEITÃO FILHO, H. de F. Considerações sobre a florística de florestas tropicais e subtropicais do Brasil. Piracicaba, IPEF 35, p.41-46. 1987.

LORENZI, H. Árvores brasileiras : manual de identificação e cultivo de plantas arbóreas nativas do Brasil. Nova Odessa, Ed. Plantarum, 1992. 352 p.

LUCAS, R., HONZAK, M., AMARAL, I., CURRAN, P., FOODY, G. \& AMARAL, S. Composição florística, biomassa, e estrutura de florestas tropicais em regeneração : uma avaliação por sensoriamento remọto. In : GASCON, C. \& MOUTINHO, P. (org.) Floresta Amazônica : dinâmica, regeneração e manejo, 1998. p.61-83.

LUGO, A. E. The future of the forest - ecosystem rehabilitation in the tropics. Environment 30: 16-20, 41-45. 1988.

MACDICKEN, K.G. \& VERGARA, N.T. Introduction to Agroforestry. Wiley, 1990. 382p.

MARTIN, G. J. Ethnobotany: a methods manual. London, U.K.Chapman \& Hall, 1995. 267p.

MARTINEZ-RAMOS, M. Claros, ciclos vitales de los arboles tropicales y regeneración natural de las selvas altas perenifolias. In: GOMEZ-POMPA, A. \& SILVA DEL AMO, R. (eds.). Investigaciones sobre la regeneración de selvas altas en Vera Cruz, Mexico. 1985. Tomo II. p.-191-240 
METZGER, J. P. Changements de la structure du paysage et richesse spécifique des fragments forestiers dans le sud-est du Brésil. C. R. Acad. Sci. Paris, Sciences de la vie/ Life sciences 321, p.319-333. 1998.

MORELLATO, L. P. Estudo da fenologia de árvores, arbustos e lianas de uma floresta semidecídua no sudeste do Brasil. Campinas, 1991. 176 p. Tese (Doutorado), Universidade Estadual de Campinas.

MURCIA, C. Edge effects in fragmented forests: implications for conservation. Trends in Ecology and Evolution, 10, p.58-62. 1995.

NAIR, P. K. R. An introduction to Agroforestry. The Netherlands, Kluwer Academic Publishers with ICRAF. 1993. p.496.

NASCIMENTO, H. E. M. Estntura e dinâmica de populações arbóreas de um fragmento de floresta estacional semidecidual na região de Piracicaba, S.P. Piracicaba, 1998. 78p. Tese (mestrado)- Escola superior de agricultura Luiz de Queiroz, Universidade de São Paulo.

NELSON, N. \& WRIGHT, S. Power and participatory development - theory and practice. Intermediate Technology Publications, London, UK. 1995. 223p.

NEPSTAD, D. C., UHL, C., PEREIRA, C, \& SILVA, J. M. C. Barreiras ao estabelecimento de árvores em pastos abandonados na Amazônia : banco de sementes, predação de sementes, herbivoria e seca. In: GASCON, C. \& MOUTINHO, P. (org.) Floresta Amazônica : dinâmica, regeneração e manejo, Manaus, 1998. p.191-218.

OLDEMAN, R. A. A. The design of ecologically sound agroforests. In : Plant research and agroforestry . ICRAF, Nairobi, Kenya, 1983a. p.173-207.

OLDEMAN, R. A. A. Tropical rain forest, a rchiteture, silvigenesis and diversity. In: Tropical rain forest: ecology and management. Oxford, Blackwell Scientific Publications. 1983b. p.131-50.

OLDEMAN, R. A. A. Forests: elements of silvology. Springer Verlag, Berlin, 1990. 624p. 
OLDEMAN, R. A. A. Architectural models, fractals and agroforestry design. In : Agriculture, Ecosystems and Environment, 41, Amsterdam, Elsevier Science Publishers B.V., 1992. p.179-188.

OLDEMAN, R. A. A. \& DIJK, J. V., Diagnosis of the temperament of tropical rain trees. In : GÓMEZ-POMPA, A., WHITMORE, T. C. \& HADLEY, M. (Ed.) Rain forest regeneration and management. MAB series vol.6. UNESCO \& Parthenon, Paris. p.2165. 1991.

PARROTTA, J. Secondary forest regeneration on degraded tropical lands - the role of plantations as "foster ecosystems". In: LIETH, H. \& LOHMANN, M. (Ed.), Restoration of Tropical forest ecosystems. Kluwer Academic Publishers, The Netherlands, 1993. p.6373.

PENEREIRO, F. M. Sistemas agroflorestais dirigidos pela sucessão: um estudo de caso. Piracicaba, 1999. Tese (mestrado)- Escola Superior de Agricultura Luiz de Queiroz, Universidade de São Paulo.

PETERSEN, P. Diagnóstico ambiental rápido e participativo: levantando informações e mobilizando a comunidade para um manejo sustentável das terras. Cadernos de Agroecologia - Solos. AS-PTA, 1996. p.22-28.

PRIMACK, R. B. Essentials of conservation biology. Massachussets: Sinauer Press, 1993. $564 \mathrm{p}$.

POSEY, D. A. The application of ethnobiology in the conservation of dwindling natural resources : lost knowledge or options for the survival of the planet. In : Ethnobiology: implications and applications - Proceedings of the first international congress of ethnobiology, Vol. 1, Belém, 1988. p.47-59.

PUTZ, F. E. Liana biomass and leaf area of a Tierra Firme forest in the Rio Negro basin, Venezuela. Biotropica, St. Louis, 15: 185-9, 1983.

REMMERS, G. G. A. Con cojones y maestría. Wageningen, 1998. Thesis (PhD) 380p. Wageningen University. 
RODRIGUES, R. R., SILVA, I. C., CAPELLARI, L., SOUZA, V. C. \& REBELLO, J. F. S. Trilhas do Parque da ESALQ - árvores medicinais. Piracicaba, ESALQ/FNMA, 1996. $28 \mathrm{p}$.

ROSSIGNOL, M., ROSSIGNOL, L., OLDEMAN, R. A. A. \& BENZINE-TIZROUTINE, S. Struggle of life or the natural history of stress and adaptation. TREEBOOK 1 . The Netherlands. 1998. 237 p.

SAUNDERS, D. A., HOBBS, R. J. \& MARGULES, C. R. Biological consequences of ecosystem fragmentation: a review. Conservation Biology, 5, 1, p.18-28. 1991.

SECRETARIA DO MEIO AMBIENTE. Estabelecimento de metas ambientais e reenquadramento dos corpos d'água. São Paulo, 1994.

SCHELhaS, J. \& GREenberG, R. Forest Patches in Tropical Landscapes. Island Press. 1996. $425 \mathrm{p}$.

SHANLEY, P. GALVÃO, J. \& LUZ, L. Limits and strengths of local participation: a case study in eastem Amazonia. PLA Notes - notes on participatory learning and action. Methodological complementarity n. 28. IIED - International Institute for Environment and Development. 1997. p. 64-67.

SKOLE, D. \& TUCKER, C. Tropical deforestation and habitat fragmentation in the Amazon: sattelite data from 1978 to 1988 . Science $260: 1905-10.1993$.

SOS MATA ATLÂNTICA \& INSTITUTO NACIONAL DE PESQUISAS ESPACIAIS. Evolução dos remanescentes florestais e ecossistemas associados do domínio da Mata Atlântica no período 1985-1990 - Relatório. São Paulo. 1993. 46p.

TABANEZ, A. A. J. Ecologia e manejo de ecounidades em um fragmento florestal na região de Piracicaba, São Paulo. Piracicaba. 85p. Tese (Mestrado)- Escola Superior de Agricultura Luiz de Queiroz. Universidade de São Paulo.1995.

TABANEZ, A. A. J., VIANA, V. M. \& PINHEIRO, L. F. V. Ecologia da paisagem de Piracicaba, S.P. CONGRESSO NACIONAL DE BOTÂNICA, São Leopoldo, UVRS. Resumos. 1994. 
TELLES JÚNIOR, A. Q. O cheiro do mato. Rio de janeiro, AS-PTA. 1991. 26 p.

VESTER, $H$. The trees and the forest - the role of tree architeture in canopy development; a case study in secondary forests (Araracuara, Colômbia). 1997. 180 p.

VIANA, V. M. Seed dispersal and gap regeneration: the case of three Amazonian species. Cambridge, 1989. 270p. (PhD ) Harvard University.

VIANA, V. M. Biologia e manejo de fragmentos florestais. In: VI CONGRESSO FLORESTAL BRASILEIRO, Anais. 1990. Campos do Jordão, Sociedade Brasileira de Silvicultura e Sociedade de Engenheiros Florestais. p.113-118.

VIANA, V. M. Conservação da biodiversidade de fragmentos florestais em paisagens tropicais intensamente cultivadas. ABORDAGENS INTERDISCIPLINARES PARA A CONSERVAÇÃO DA BIODIVERSIDADE E DINÂMICA DO USO DA TERRA, Belo Horizonte, 1995, p.135-154.

VIANA, V. M. Introdução. In : GASCON, C. \& MOUTINHO, P. (org.) Floresta Amazônica : dinâmica, regeneração e manejo, Manaus, 1998. p.15-24.

VIANA, V. M. \& PINHEIRO, L. F. V. Conservação da biodiversidade em fragmentos florestais. II SIMPÓSIO SOBRE ECOLOGIA E MANEJO DE FRAGMENTOS FLORESTAIS. Anais. Piracicaba, SP. 1998.

VIANA, V. M. \& TABANEZ, A. J. Biology and conservation of forest fragments in the Brazilian Atlantic moist forest. In : SCHELLAS, J. \& GREENBERG, R. Forest Patches in Tropical landscapes; Washington D.C., Island Press, 1996. p.151-167.

VIANA, V. M., MATOS, J. C. de S. \& AMADOR, D. B. Sistemas agroflorestais e o desenvolvimento rural sustentável no Brasil. XXVI CONGRESSO BRASILEIRO DE CIÊNCIA DO SOLO. Anais. EMBRAPA. Rio de Janeiro, 1997a. 18 p.

VIANA, V. M., OLDEMAN, R. A. A., VAZ, P., AMADOR, D. B. et al. Manejo ecológico de ecossistemas e desenvolvimento sustentável. CURSO BIOLOGIA E SILVICULTURA DE ESPÉCIES ARBÓREAS TROPICAIS. Anais. São Joaquim da Barra, 1998. 154p. 
VIANA, V. M., TABANEZ, A. J. \& BATISTA, J. L. Dynamics and restoration of forest fragments in the Brazilian Atlantic moist forest. In : LAURANCE, W., BIERREGARD, R. O. \& MORITZ, C. (Ed.) Tropical forest remnants : ecology, management and conservation of fragmented communities. 1997b. p.351-365.

VIANA, V. M., TABANEZ, A. J. A. \& MARTINEZ, J. L. A. Restauração e manejo de fragmentos de florestas. II CONGRESSO NACIONAL SOBRE ESSÊNCIAS NATIVAS, 2. São Paulo, 1992. Anais. Instituto florestal de São Paulo. p. 400.

VICTOR, M. A. M. A devastação florestal. São Paulo. Sociedade Brasileira de Silvicultura. 1975. 48p.

VIVAN, J. Agricultura e florestas - princípios de uma interação vital. AS-PTA, Livraria e Editora agropecuária, Rio de Janeiro. 1998. 207 p.

WHITMORE, T. C. Tropical forest disturbance, disappearance, and species loss. In : LAURANCE, W., BIERREGARD, R. O. \& MORITZ, C. (Ed.) Tropical forest remnants: ecology, management and conservation of fragmented communities. 1997. p.3-12.

WHITMORE, T. C. Tropical rain forest dynamics and its implications for management In: GÓMEZ-POMPA, A., WHITMORE, T. C. \& HADLEY, M. (Ed.). Rain forest regeperation and management - Man and Biosphere series, v.6, Parthenon Publishing, 1991. p.67-90.

YOXNGG, A. \& MITCHELL, N. Microclimate and vegetation edge effects in a fragmented podocarp-broadleaf forest in New Zealand. Biological Conservation, Barking, 67: 63-72, 1994. 